\author{
UNIVERSIDADE DE SÃO PAULO \\ ESCOLA DE ENFERMAGEM DE RIBEIRÃO PRETO
}

DANIELA BORGES BITTAR

Violência intrafamiliar: um estudo com mães agressoras usuárias de álcool e drogas 
DANIELA BORGES BITTAR

\title{
Violência intrafamiliar: um estudo com mães agressoras usuárias de álcool e drogas
}

\author{
Dissertação apresentada à Escola de \\ Enfermagem de Ribeirão Preto da \\ Universidade de São Paulo para obtenção do \\ título de Mestre em Ciências, Programa de \\ Pós-Graduação em Enfermagem em Saúde \\ Pública. \\ Linha de pesquisa: Assistência à saúde da \\ mulher no ciclo vital. \\ Orientador (a): Profá. Dra. Ana Márcia Spanó \\ Nakano.
}


Autorizo a reprodução e divulgação total ou parcial deste trabalho, por qualquer meio convencional ou eletrônico, para fins de estudo e pesquisa, desde que citada a fonte.

\section{FI CHA CATALOGRÁFI CA}

Bittar, Daniela Borges.

Violência intrafamiliar: um estudo com mães agressoras usuárias de álcool e drogas / Daniela Borges Bittar; orientadora Ana Márcia Spanó Nakano - Ribeirão Preto, 2010.

160f. : il. ; $30 \mathrm{~cm}$

Dissertação (Mestrado) apresentada à Escola de Enfermagem de Ribeirão Preto/USP. Área de concentração: Enfermagem em Saúde Pública.

1. Violência doméstica. 2. Transtornos relacionados ao uso de substâncias. 3. Relações mãe-filho. 


\section{FOLHA DE APROVAÇÃO}

BITTAR, Daniela Borges

Violência intrafamiliar: um estudo com mães agressoras usuárias de álcool e drogas

Dissertação apresentada à Escola de Enfermagem de Ribeirão Preto da Universidade de São Paulo, para obtenção do título Mestre em Ciências, Programa de PósGraduação em Enfermagem em Saúde Pública.

Aprovado em ....../ ....../ .........

Banca Examinadora

Prof. Dr.

Instituição:

Assinatura

Prof. Dr.

Instituição:

Assinatura

Prof. Dr.

Instituição: Assinatura 


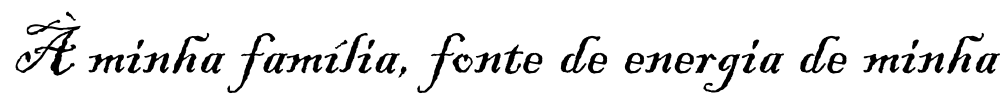
vida, e ao meu amado Daniel, pelo carintio, amor e compreensäo. 


\section{AGRADECI MENTOS}

Agradeço, primeiramente, a Deus, por ter me proporcionado a realização deste sonho.

À Profa . Dra. Ana Márcia Spanó Nakano, minha brilhante orientadora, pela confiança, profissionalismo, compreensão e pelo respeito e estímulo ao pensar.

À Profa. Dra. Eliana Mendes de Souza Teixeira Roque, um grande e verdadeiro exemplo de competência, responsabilidade, ética e sensibilidade; um ser humano maravilhoso com quem criei verdadeiros laços de amizade.

Às mulheres que participaram desta pesquisa, por emprestarem a luta cotidiana de suas vidas à construção de um trabalho tão rico e emocionante.

A todos os componentes do grupo "Intervenções breves para pessoas que abusam de álcool e drogas", pela convivência, pelo afeto, pela troca, pela criatividade, pelos belos encontros, pelos trabalhos que desenvolvemos juntos, enfim, por transformarem meus conceitos e preconceitos.

Agradeço também aos amigos que conheci neste percurso, pelas conversas e pela amizade que se consolidou durante o mestrado, caminho geralmente tão solitário.

Agradeço aos membros da banca, pela disponibilidade para avaliar este trabalho e valiosas sugestões. 
Agradeço imensamente à minha família, aos meus pais, Lindomar e Norma, exemplos de força em meio a tantas adversidades, pela liberdade e respeito às minhas escolhas sempre, pelo estímulo e pelo apoio em horas tão difíceis. Sem eles não só este trabalho, mas muitas outras conquistas não seriam possíveis.

Ao meu irmão Deivid, pelo amor.

À Dayana, minha irmã, pelo amor e por construir comigo uma amizade a cada dia mais bonita e fundamental em minha vida.

Aos amigos, antigos e recentes, pelo prazer de compartilhar a vida e por possibilitarem um 'lugar no mundo'; agradeço aos que se fizeram presentes e especialmente aos que puderam estar tão próximos nos últimos tempos: Tayana, Daniela Daltoso, Joelma, acompanhando o processo de construção deste trabalho, por vezes tão angustiante, e por compartilharem também de momentos tão importantes e significativos nesta convivência.

Finalmente, agradeço ao Daniel, meu marido, a quem tanto amo e admiro, por nossa história, pelo companheirismo, pela sensibilidade, pelo cuidado e pelo apoio sempre, pela rotina surpreendente e apaixonante, por sua leveza, pelo prazer do encontro todos os dias (ou quase todos os dias!). Agradeço a ele por me fazer gostar mais de viver a cada dia. 
Sonhar

Mais um sonho impossível

Lutar

Quando é fácil ceder

Vencer 0 inimigo invencível

Negar quando a regra é vender

Sofrer a tortura implacável

Romper a incabível prisão

Voar num limite improvável

Tocar o inacessível chão

É minha lei, é minha questão

Virar esse mundo

Cravar esse chão

Não me importa saber

Se é terrível demais

Quantas guerras terei que vencer

Por um pouco de paz

$E$ amanhã, se esse chão que eu beijei

For meu leito e perdão

Vou saber que valeu delirar

E morrer de paixão

E assim, seja lá como for

Vai ter fim a infinita aflição

E o mundo vai ver uma flor

Brotar do impossível chão

(Chico Buarque e Ruy Guerra - Sonho Impossível) 


\section{RESUMO}

BITTAR, D. B. Violência intrafamiliar: um estudo com mães agressoras usuárias de álcool e drogas. 2010. 160 f. Dissertação (Mestrado) - Escola de Enfermagem, Universidade de São Paulo, Ribeirão Preto, 2010.

A violência é considerada, mundialmente, violação de direitos, embora com expressões variadas em diferentes contextos. Não bastam para seu controle apenas apelos aos sensos de responsabilidade ética e social dos indivíduos. Trata-se, antes, da redefinição desses sensos, do ponto de vista moral e legal. Historicamente, a violência atinge todos os setores da sociedade, sendo um fenômeno multideterminado. Compreender os determinantes da violência é um dos importantes passos, na saúde pública, para a prevenção e atenção desse fenômeno. Nesta direção, é que buscamos neste estudo compreender como mães usuárias de álcool e drogas significam a violência perpetrada junto aos seus filhos, tendo por base seu contexto histórico e social, a fim de entender suas ambiguidades e os motivos da agressão; o que perpassa pela análise da construção social para o exercício dos papéis maternos e de fatores associados, tais como sua condição social e relacional, além do consumo de álcool e drogas. Para a compreensão do objeto de estudo, optamos pela abordagem qualitativa; o recorte empírico foi dado por saturação, sendo composto por dez mulheres, mães, maiores de 18 anos, as quais vivem em um contexto de álcool, drogas e violência, na cidade de Jardinópolis/SP. Para a coleta de dados utilizou-se da entrevista do tipo História de Vida; e, para o tratamento dos dados, a análise de conteúdo, modalidade temática. Após o processo de organização do material coletado nas entrevistas, apreendemos das falas das mulheres dois momentos distintos de suas vidas: o seu passado na família de origem e o seu presente na família atual que, embora separados pelo tempo, guardam relações. Essas, estando ou não conscientes para as mulheres, deixam marcas indeléveis em suas vidas. Dentro da trajetória de vida no contexto da família de origem, temos as seguintes categorias temáticas: convivendo com as perdas: “... eu fiquei pro mundo"; convivendo com alcoolismo, pobreza e violência em família; e convivendo com afetos e desafetos: "eu achava tão bom, tão gostoso quando ela me chamava de filha, era muito raro, muito raro". Dentro do contexto da família atual temos: "Eu tentei construir uma família... bem ou mal ela tá aí"; "Minha vida da infância ao casamento parece que foi igual (...) continuei sendo agredida" e "Eu bato nele sim (...), mas em vista do que eu fui tratada, eu trato ele muito bem". Entendemos que compreender estas questões nos possibilita encontrar caminhos que vão além de medidas protetivas, como comumente se utiliza a violência infantil, mantendo crianças em abrigos. A família é reconhecidamente fundamental no trabalho de proteção integral a crianças e adolescentes. Acreditamos ser importante um trabalho junto aos agressores, que também requerem ser cuidados, ajudando-os a encontrar caminhos para recuperarem sua dignidade e respeitabilidade.

Palavras-chave: Violência doméstica. Transtornos relacionados ao uso de substâncias. Relações mãe-filho. 


\section{ABSTRACT}

BITTAR, D. B. Domestic Violence: a study with aggressive mothers users of alcohol and drugs. 2010. $160 \mathrm{f}$. Thesis (Masters). University of São Paulo, College of Nursing, Ribeirão Preto, 2010.

Violence is considered a world-wide violation of rights, although with varied expressions in different contexts. Appeals to the senses of ethics and social responsibility of individuals are not enough to control it. It is rather a redefinition of these senses, the morally and legally. Historically, violence affects all sectors of society, being a multi-determined phenomenon. Understanding the determinants of violence is a major step in public health for the prevention and treatment of this phenomenon. In this sense, we propose the present study that aims at understanding how mothers who use alcohol and drugs mean the violence with their children, based on its historical and social context in order to understand its ambiguities and the reasons for aggression, which run through the analysis of social housing for the exercise of maternal roles and associated factors, such as their social and relational, and the consumption of alcohol and drugs. To understand the object of the study, we chose the qualitative approach, the empirical cutgiven saturation is composed of ten women, mothers over 18 years old, who live in a context of alcohol, drugs and violence in the city of Jardinópolis/SP. To collect data we used the Life History interviews, and for the processing, we used content analysis and thematic modality. After the process of organizing the material collected in the interview, we grasped the words of the two women at different times of their lives: their past in the original family and their present in the present family - both moments that although separated by time, keep relationships. These words, being aware or not by the women, leave indelible marks on their lives. Within the life course in the context of the family of origin we have the following themes: dealing with losses: "...I got to the world"; dealing with alcoholism, poverty and domestic violence; dealing with affection and disaffection, "I felt so good, so good when she called me her daughter, it was very rare, very rare." Within the context of the present family we have: "I tried to build a family ... good or bad it's done", "My life from childhood to marriage seems to have been the same (...) I was always under attack" and "I beat him but (...), considering the way I've been treated, I deal with it very well". We believe that understanding these issues enables us to find ways that go beyond the protective order, as is commonly used child abuse while keeping children in shelters. The family is recognized as fundamental in the work of full protection to children and adolescents. We believe it is important to work with the aggressors, who also require care, by helping them find ways to regain their dignity and respectability.

Key-words: Domestic violence. Substance-related disorders. Motherchild relations. 


\section{RESUMEN}

BITTAR, D.B. La Violencia familiar: un estudio con madres agresoras y usuarias de alcohol y drogas. 2010. 160 f. Disetación. (Maestría). Escuela de Enfermería, Universidad de São Paulo, Ribeirão Preto, 2010.

La violencia es considerada mundialmente violación de derechos, aunque con diversas expresiones en diferentes contextos. No es suficiente para su control sólo la apelación a la responsabilidad ética social de las personas. Es más bien una redefinición de estos sentidos, desde la moral y la legalidad. Históricamente, la violencia afecta a todos los sectores de la sociedad, figurando un fenómeno multideterminado. Comprensión de los determinantes de la violencia es un paso importante en la salud pública para la prevención y el tratamiento de este fenómeno. En este sentido, estamos proponiendo este estudio, que busca entender cómo las madres que consumen alcohol y drogas perciben la violencia hacia sus hijos, en función de su contexto histórico y social, con el fin de entender sus ambigüedades y las razones de la agresión, que implica un análisis de la construcción social para el ejercicio de las funciones maternas y los factores asociados, tales como su desarrollo social y relacional, además del consumo de alcohol y de drogas. Para entender el objeto de estudio, elegimos el enfoque cualitativo, el corte empírico dado por saturación, y que se compone de diez mujeres madres mayores de 18 años, que viven en un contexto de alcohol, drogas y violencia, en la ciudad de Jardinópolis/SP. Para recoger los datos se utilizó la entrevista tipo historia de vida, y para el procesamiento de los datos, el análisis de contenido, modalidad temática. Después del proceso de organización de los materiales recogidos en la entrevista, inferimos de los discursos de mujeres dos momentos distintos de sus vidas: su pasado en su familia de origen y su presente en la familia actual que, aunque separados por el tiempo, mantienen relaciones. Estas, conscientes o no para las mujeres, dejan huellas indelebles en sus vidas. En el curso de la vida en el contexto de la familia de origen tenemos los siguientes temas: viviendo con las pérdidas: "...me dejaron para el mundo"; viviendo con el alcoholismo, la pobreza y la violencia en la familia y viviendo con los afecto y desafectos, "Me sentía estupenda cuando ella me llamaba de hija, lo que era muy raro, muy raro". En el contexto de la familia actual, tenemos: "Intenté formar una familia... bueno o malo ahí está ella", "Mi vida desde la infancia hasta el matrimonio parece haber igual (...) seguí siendo agredida" y "Le pego a el sí (...), pero frente a como me trataron, lo cuido muy bien". Creemos que la comprensión de estos temas nos permite encontrar formas que van más allá de las medidas de protección, como son comúnmente utilizadas, mantiéndose a los niños en los albergues. La familia es reconocida como fundamental en la labor de protección integral a los niños y adolescentes. Creemos que es importante un trabajo junto a los agresores, que también requieren atención, ayudándoles a que encuentren maneras de recuperar su dignidad y respetabilidad.

Palabras-claves: Violencia doméstica. Trastornos relacionados con sustancias. Relaciones madre-hijo. 


\section{SUMÁRIO}

1 Introdução

2 Objetivos 24

2.1 Geral 24

2.2 Específicos. 24

\section{Marco Teórico Conceitual}

3.1 Dimensão conceitual da violência contemporânea e políticas de controle e proteção a grupos vulneráveis - crianças e adolescentes.

3.2 A construção social da mulher para a maternidade e o movimento de proteção a infância..

3.3 A família e as dissociações dos papéis maternos como base à compreensão da violência intrafamiliar....

3.4 O consumo de álcool e drogas na família como fator de risco para violência

4 Pressupostos

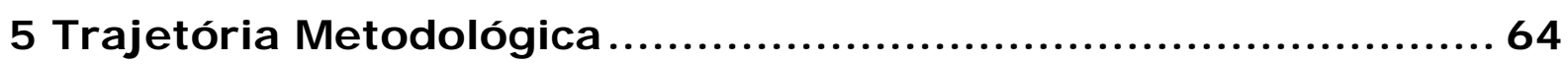

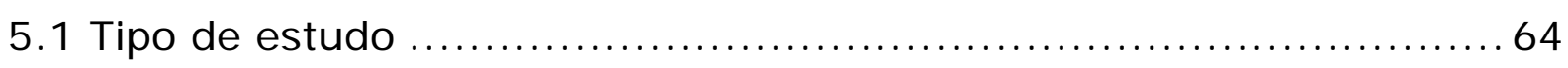

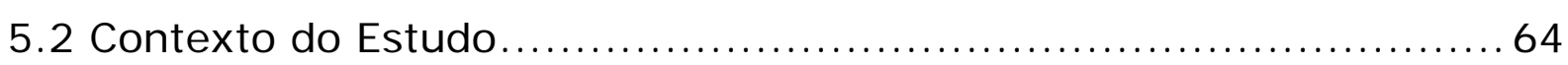

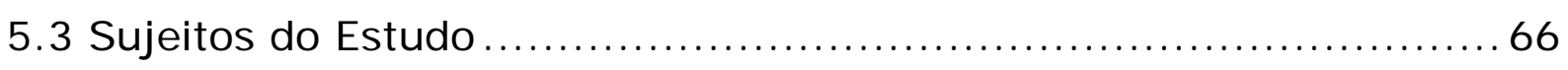

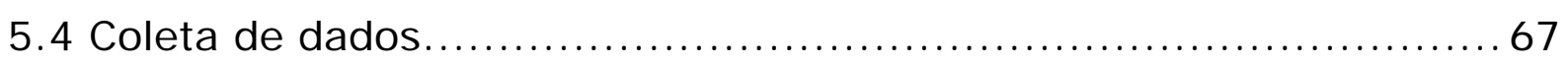

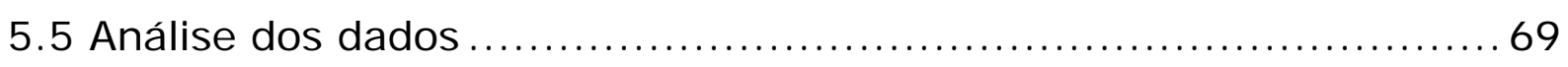

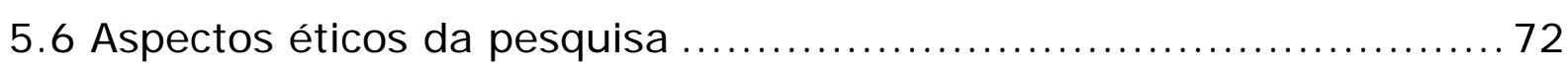


6.1 Perfil das mães que manifestam atos de violência contra seus filhos 73 6.2 Significando a violência contextualizada na família anterior e atual

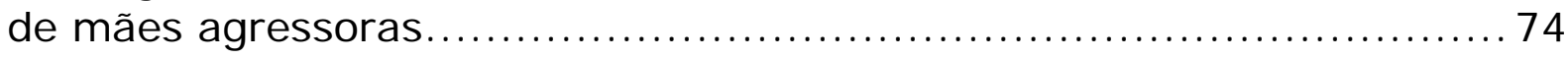

6.2.1 Trajetória de vida no contexto da família de origem ................ 75

6.2.2 O contexto da família atual: repetindo trajetórias de vida ...........93

7 A compreensão da dissociação do papel materno que se expressa em violência contra a criança/ adolescente................ 115

REFERÊNCIAS

ANEXO

ANEXO I - Aprovação pelo Comitê de Ética....

APÊNDI CES

APÊNDICE A - Aspectos a serem contemplados na História de Vida ..... 144

APÊNDICE B - Solicitação de autorização para a pesquisa ................. 146

APÊNDICE C - Termo de Consentimento Livre e Esclarecido .............. 149

APÊNDICE D - Breve perfil dos sujeitos do estudo ..................... 151 


\section{I ntrodução}

Debate-se, contemporaneamente, a expansão de domínios da violência, de modo paradoxal com a expansão dos direitos humanos e sociais (SCHRAIBER; D'OLIVEIRA; COUTO, 2006), os quais clamam por garantias de uma convivência digna, livre e igual para todas as pessoas (PEIXOTO, 2006).

A violência é considerada mundialmente violação de direitos, embora com expressões variadas em diferentes contextos. Não bastam para seu controle apenas apelos aos sensos de responsabilidade ética e social dos indivíduos. Trata-se, antes, da redefinição desses sensos, do ponto de vista moral e legal (SCHRAIBER; D'OLIVEIRA; COUTO, 2006). Historicamente a violência atinge todos os setores da sociedade, sendo um fenômeno multideterminado.

Nas duas últimas décadas do século $X X$, nas grandes cidades do mundo e em alguns países, como é o caso do Brasil, os dados epidemiológicos têm mostrado crescimento da morbidade e da mortalidade por causas externas (PRIULI; MORAES, 2007).

Estimativas da Organização Mundial de Saúde (OMS) para o ano de 2000 destacam a ocorrência de cerca de 1,6 milhões de mortes de pessoas no mundo inteiro como resultado da violência, sendo $25 \%$ dessa mortalidade por acidentes de transporte, $16 \%$ por suicídio, 10\% por violência interpessoal, $9 \%$ por afogamento, dentre outras (OMS, 2002).

De acordo com os dados do Relatório Mundial sobre Violência e Saúde (OMS, 2002), constata-se que a taxa de homicídios no Brasil foi de 23 por 100.000 habitantes, sendo que a da Colômbia foi de 61,6 por 100.000 habitantes. Já na África como um todo, a taxa estimada para o ano de 2000 foi de, aproximadamente, 22 homicídios por 100.000 habitantes. Enquanto isso, observa-se para alguns países europeus taxas comparativamente muito baixas, como da Dinamarca $(1,1)$; França $(0,7)$; Alemanha (0,9); Grécia (1,2); Portugal $(1,1)$; Reino Unido $(0,8)$; Espanha 
$(0,8)$; dentre outros. As maiores taxas encontradas na Europa foram da Albânia (21) e da Federação Russa $(21,6)$.

Nos Estados Unidos, estima-se que as consequências da violência interpessoal - que inclui violência entre membros da família, entre casais, violência juvenil e entre pessoas estranhas - são de alto custo, chegando a um patamar de 3,3\% do Produto Interno Bruto (PIB) do país. O fenômeno afeta principalmente países de menor poder aquisitivo, sendo que o efeito econômico dessa violência é mais severo em países pobres, onde são escassos estudos e políticas sobre esse assunto (WORLD HEALTH ORGANIZATION, 2004a, 1999a).

Com relação à dimensão econômica da violência interpessoal, é importante colocar que os gastos ocorridos em sua prevenção são bem menores do que os gastos para repará-la. Ainda nos Estados Unidos, intervenções que tinham como foco agressões juvenis resultaram em benefícios econômicos trinta vezes maiores que os gastos para reparar esse tipo de violência (WORLD HEALTH ORGANIZATION, 2004a).

No panorama brasileiro, o aumento da mortalidade por causas violentas vem se tornando um fenômeno de alta relevância; as doenças da modernidade são as que mais matam no Brasil. Dados do Ministério da Saúde (BRASIL, 2008) confirmam que o perfil da mortalidade no país mudou ao longo dos anos, acompanhando a tendência mundial de mais mortes por doenças crônicas e violentas.

Apesar de estudos do Ministério da Saúde apontarem para uma redução na tendência de mortes por homicídios, principal causa específica do grupo das externas, essa mortalidade se mantém em patamar elevado, principalmente nos homens jovens, de baixa escolaridade e negros.

No início da década de 80 , a mortalidade por causas violentas ocupava o quarto lugar no perfil das principais causas de óbito, passando para o segundo lugar, a partir de 1989, perdendo apenas para as doenças do aparelho circulatório. Atualmente, respondem pela terceira posição no ranking da mortalidade no Brasil. Os dados regionais mostram um cenário preocupante: as causas externas são a segunda maior causa de óbitos em 
três das cinco regiões do país - Norte, Centro-Oeste e Nordeste. No Sudeste e no Sul, as causas externas ocupam o terceiro lugar (BRASIL, 2008).

A epidemia de mortes violentas é uma das pautas da nova agenda da saúde pública, com sinais de evolução desfavorável, remetendo para um cenário futuro inquietante (MINAYO, 1990; MINAYO; ASSIS, 1994; MINAYO; SOUZA, 1999; MONTEIRO, 2000).

Frente a esta realidade, observam Schraiber, D'Oliveira e Couto (2006) que não se pode aceitar a violência como fato corriqueiro e, particularmente, no campo da saúde, não se deve reduzir a atenção apenas em suas consequências à saúde; chamando para responsabilidade dos profissionais e cientistas da saúde, em conjunção com outros setores da sociedade, a fim de que se preocupem com a prevenção e intervenham, posicionando-se no combate à violência.

O Relatório Mundial sobre Violência e Saúde (OMS, 2002) tornou público e mundial o problema da violência, ampliando o debate e permitindo a construção de referências para os diversos movimentos regionais. De outro lado, valoriza e resignifica esse problema, além de conferir um todo à problemática: unifica-se a violência enquanto questão a ser enfrentada, ao mesmo tempo em que se definem as distintas violências enquanto diversidades dessa questão plural.

Esse relatório mundial coloca a definição de violência como:

o uso intencional da força física ou do poder, real ou em ameaça contra si próprio, contra outra pessoa, ou contra um grupo ou uma comunidade, que resulte ou tenha possibilidade de resultar em lesão, morte, dano psicológico, deficiência de desenvolvimento ou privação de liberdade (OMS, 2002, p.48).

Ainda no relatório, se reconhece que a invisibilidade da violência revela-se em taxas subestimadas de sua ocorrência, principalmente quando esta não resulta em mortes ou lesões graves, mas oprime e gera danos físicos, psicológicos e sociais nos indivíduos que se encontram submetidos de forma crônica aos abusos. 
Dentre os diversos tipos de violência, destacamos, neste estudo, a violência intrafamiliar. Dimensionar a magnitude da violência intrafamiliar ainda é um desafio para os pesquisadores da área, sendo difícil estimar sua frequência de ocorrência (BARNETT; MILLER-PERRIN; PERRIN, 1997; STRAUS; GELLES, 1995). No entanto, há evidências crescentes de que o problema é significativo e universal (ASSIS, 1994; BARNETT; MILLER-PERRIN; PERRIN, 1997; BRASIL, 2002; DESLANDES, 1994a; MONTEIRO; PHEBO, 1992; MORAES; REICHENHEIM, 2002; KRUG et al., 2002; NOEL; YAM, 1992).

Embora a violência intrafamiliar não seja uma ocorrência exclusiva de determinada classe, faixa etária ou população, esta tende a vitimizar, prioritariamente, certos grupos da sociedade, como mulheres, crianças e idosos. Além disso, alguns fatores são tidos como agravantes, quando presentes, podendo facilitar a ocorrência de violência na família (DOSSI et al., 2008).

Particularmente sobre a violência intrafamiliar contra crianças, chamam a atenção, no Relatório, as altas taxas de mortalidade, que se apresentam desiguais pelos países e por sexo. A taxa de homicídio de zero a quatro anos $(5,2$ por 100 mil) é mais que o dobro que aquela de crianças entre cinco a 14 anos (2,1 por 100 mil). Para crianças menores que cinco anos, a taxa de homicídio em países de alta renda é de 2,2 por 100 mil meninos e 1,8 por 100 mil meninas, sendo que em países mais pobres são duas a três vezes maiores (6,1 por 100 mil meninos e 5,1 por 100 mil meninas) (KRUG et al., 2002).

Quanto à morbidade, as crianças mais jovens estão mais expostas à violência física (75\% nas Filipinas a $47 \%$ nos Estados Unidos, em relato dos pais), enquanto que os adolescentes à violência sexual, calculando-se que cerca de $20 \%$ das mulheres e $5 \%$ a $10 \%$ dos homens sofreram abuso sexual quando crianças. Desigualdades sociais e questões de gênero estão também implicadas na violência contra crianças e adolescentes (KRUG et al., 2002). 
Várias pesquisas apontam para as grandes proporções com que a violência ocorre na infância, apesar de subestimada oficialmente em todo o mundo (MERRICK; BROWNE, 1999; MIAN, 2004). Nos Estados Unidos, cerca de 1,5 milhão de crianças são vítimas de maus-tratos e $6,3 \%$ dos casais vivenciam alguma forma de violência grave a cada ano (STRAUS; GELLES, 1995). Em 2000, considerando apenas os casos notificados às agências de proteção à criança nos EUA e que foram confirmados, 12 de cada 1.000 crianças haviam sido vítimas de maustratos, assim distribuídos: negligência $-62,8 \%$, abuso físico $-19,3 \%$, abuso sexual - 10,1\% e abuso psicológico - 7,7\% (GOLDMAN et al., 2003). Dados semelhantes também foram observados por Trocmé et al. (2003), no estudo realizado em três grandes províncias (Ontário, Québec e Alberta) do Canadá.

Um inquérito realizado diretamente com crianças e seus responsáveis, em âmbito nacional nos EUA, verificou que mais de um em cada oito crianças e jovens entre dois e 17 anos haviam sofrido alguma forma de maus-tratos no ano estudado (FINKELHOR et al., 2005).

No Brasil, estima-se que $20 \%$ das crianças e adolescentes sejam, hoje, vítimas de alguma forma de violência (MINAYO, 2004a), mas não há pesquisas a nível nacional que tenham avaliado a extensão dos maus-tratos praticados contra indivíduos nessa faixa etária.

Estudo nacional recente, como o de Costa et al. (2007), realizado no município de Feira de Santana, Bahia, no período de 2003 a 2004, revelou que de 1.293 casos de violência contra crianças e adolescentes, a grande maioria das ocorrências se passaram no domicílio, 1.011. Entre as violências denunciadas, a negligência apresentou o maior número de casos, 727; seguidos pelas violências física, 455, psicológica, 374 e sexual, 68 .

Vale considerar que, uma vez que nem todos os casos são notificados e nem todas as notificações são verificáveis, esses dados representam apenas uma aproximação da realidade (FERREIRA, 2005). 
A revelação de casuísticas fidedignas é essencial e se apresenta como uma etapa inicial para o desenvolvimento de programas de atuação (BLACK; SLEP; HEYMAN, 2001; HEYMAN; SLEP, 2001; PETRIODOU et al., 2002). A elaboração de processos sistemáticos de vigilância dentro dos serviços, acoplada ao desenvolvimento de ações em rede integrando os vários setores envolvidos, seriam fundamentais para a abordagem plena da violência intrafamiliar. Estudos revelam que os dados gerados no âmbito da saúde tendem a ser mais completos do que os provenientes de outros setores, tais como os oriundos dos setores policial e jurídico (DJ EDDAH et al., 2000).

A violência familiar contra crianças e adolescentes vem sendo enfrentada há algumas décadas em países desenvolvidos e nos últimos anos tem havido um crescente reconhecimento de que os serviços de saúde têm um importante papel no enfrentamento da violência intrafamiliar (BOYLE; ROBINSON; ATKINSON, 2004). Algumas estratégias para identificação de casos em serviços de saúde foram sugeridas e aplicadas. Pesquisas mostram que a inclusão de perguntas sobre eventos violentos nas fichas de atendimento de emergência pode chamar a atenção dos profissionais quanto à necessidade de abordar esta questão, aumentando a possibilidade de detecção (OLSON et al., 1996).

Benger e Pearce (2002) apontaram que a existência de um fluxograma anexado ao boletim de emergência para avaliar a presença de lesões intencionais em crianças abaixo de 5 anos com história de traumatismo elevou de forma significativa as suspeitas dos profissionais do setor. Em um estudo realizado em clínicas de pré-natal, Wiist e McFarlane (1999) mostraram que, após o desenvolvimento e a aplicação de um protocolo direcionado para violência intrafamiliar, a detecção de casos aumentou cerca de oito vezes.

Diversas possibilidades de atuação dos serviços de saúde são apontadas (WHO, 1999b; DJEDDAH et al., 2000). Através de um olhar mais atento dos profissionais da área, vislumbra-se a importância da elaboração de propostas de ação referentes à prevenção, detecção e ao 
acompanhamento do número crescente de vítimas da violência intrafamiliar (REICHENHEIM; HASSELMANN; MORAES, 1999). Observa-se também uma maior motivação em criar no setor estruturas adequadas à condução dos casos detectados, respeitando-se as características de cada serviço ou localidade por meio do conhecimento do perfil e necessidades de sua clientela (WRIGHT; CHENG, 1998).

Os serviços de saúde podem desempenhar um papel importante na implementação das modificações necessárias por se apresentarem como locais propícios à revelação dos casos de violência intrafamiliar. Esta prerrogativa pode contribuir de maneira decisiva, não só na identificação dos eventos que merecem atuação imediata ou mediata, mas também para um conhecimento mais consistente da magnitude do problema.

Há cerca de três décadas, vem sendo estudada a violência intrafamiliar, no nosso país, cometida pela família ou responsável, tanto pela magnitude, como pelas repercussões do problema (AZEVEDO, 2002).

No que diz respeito aos agressores, o estudo de Costa et al. (2007), verificou que a mãe foi o agressor que contribuiu com a maior prevalência para a negligência, $60,7 \%$; o pai contribuiu com $37,6 \%$; 0 padrasto com $24,3 \%$ e outros familiares com $25,7 \%$.

Ainda em acordo com os resultados desse estudo, segundo a faixa etária das vítimas, verificou-se que a mãe é o principal agressor das crianças com até um ano de idade (60\%), daquelas de 2 a 5 anos (acima de 50\%), assim como das faixas compreendidas entre 6 a 16 anos (40\%). O estudo também revela que a mãe apresentou-se como o principal agressor, cerca de duas vezes mais, das crianças em idades mais precoces - entre um e cinco anos - comparando às vítimas de violência da faixa etária de 17 a 19 anos.

Outro estudo realizado em Araçatuba, São Paulo, nos anos de 2001-2005, examinou agressões físicas intrafamiliares. Das 7.750 ocorrências, 1.844 estavam relacionadas à agressão física intrafamiliar: $81,1 \%$ envolvendo parceiros íntimos (grupo A), 11,6\% pais/responsáveis e filhos (grupo B) e 7,3\% outros familiares (grupo C). No tocante às 
ocorrências entre os sujeitos do grupo B, o pai destacou-se como o principal agressor físico, seguido pela mãe, sugerindo que a violência física é mais frequentemente cometida pelos pais, porém as mães também são responsáveis por esse tipo de maltrato aos filhos (DOSSI et al., 2008).

Além disso, Sacramento e Rezende (2006) expõem que as agressões físicas e os maus-tratos de ordem psicológica são remanescentes de uma cultura que compreende os castigos ou punições corporais e a desqualificação moral ou a humilhação da pessoa como recursos de socialização e práticas educativas. Minayo (2002) e Silva et al. (2002), concordam com Sacramento e Rezende, ao expor que a violência intrafamiliar é, frequentemente, justificada pelos agressores como formas de educar e corrigir transgressões de comportamento.

Observa-se a relevância de se considerar o espaço de interação entre mães e filhos em seu contexto de vida, revelando-se as multiplicidades de fatores que favorecem a expressão da violência: pobreza, relações conflitantes do casal, uso de álcool e drogas, vivência de violência conjugal na infância ou ter sofrido abuso quando criança.

A este respeito, estudos nos Estados Unidos da América evidenciaram que a violência entre o casal está presente em cerca de $40 \%$ dos casos graves ou fatais de maus-tratos contra crianças e em mais de $50 \%$ dos casos suspeitos de maus-tratos atendidos em hospitais (DUGGAN et al., 2004). Day et al. (2003), ao indagar o que provoca a violência, expõem que a tendência atual dos pesquisadores é de considerar a interação de diferentes fatores pessoais, situacionais e socioculturais combinando-se para provocar o abuso. Assim, como fatores pessoais do agressor, destacam: ter presenciado violência conjugal quando criança; ter sofrido abuso quando criança; e consumo de bebidas alcoólicas e/ou drogas. Como fatores socioculturais, destacam a pobreza, dentre outros.

Para a Associação Brasileira de Proteção à Infância e Adolescência - ABRAPIA - (1992), inúmeros fatores contribuem para 
precipitar a violência de pais contra filhos, reafirmando o exposto acima: o alcoolismo e o uso de outras drogas, a miséria, o desemprego, a baixa autoestima, problemas psicológicos e psiquiátricos. Entende-se que pais que maltratam seus filhos devem ser tratados sempre, e punidos, se necessário.

A dependência de substâncias psicoativas pelas mulheres se constitui de um dos fatores que favorecem a expressão da violência através de agressividade e atitudes negligentes para com os filhos (HOCHGRAF; BRASILIANO, 2004); realidade esta com que temos nos deparado atuando junto a famílias de crianças e adolescentes, muitos dos quais já passaram por abrigamento, e que se constituiu no universo empírico desta pesquisa.

Para Organização Pan-Americana de Saúde (2003), a maior prevalência de comportamentos violentos não pode ser explicada por um fator isoladamente e entender a maneira como os vários determinantes estão vinculados à violência é um dos passos importantes no enfoque da saúde pública, para que esse fenômeno seja prevenido.

Entendemos que compreender essa questão nos possibilita encontrar caminhos que vão além de medidas protetivas; como comumente se faz nos casos da violência infantil, mantendo crianças em abrigos, afastando-as do ambiente agressor por um período de tempo e reintroduzindo-as naquele mesmo ambiente de conflito.

Levantamento Nacional de Abrigos para Crianças e Adolescentes foi realizado pelo Instituto de Pesquisa Econômica Aplicada - IPEA (2007). Foram pesquisadas 626 instituições, em todas as regiões brasileiras, sendo que, destas, 589 oferecem programa de abrigo para crianças e adolescentes em situação de risco pessoal ou social. Encontraram-se 20 mil crianças e adolescentes nos abrigos pesquisados. A maioria é do sexo masculino $(58,5 \%)$ e afrodescendentes $(63,6 \%)$. Têm entre 7 e 15 anos de idade $(61,3 \%)$ e mais de um terço está nos abrigos há um período que varia de 2 a 5 anos. A maioria absoluta das crianças e adolescentes abrigados tem família $(86,7 \%)$ e o motivo mais citado para estarem em 
abrigos foi a pobreza (24,2\%). Destacam-se, ainda, outros motivos: abandono (18,9\%), violência doméstica $(11,7 \%)$ dependência química dos pais e responsáveis, incluindo alcoolismo (11,4\%), vivência de rua (7\%) e orfandade $(5,2 \%)$.

A família é reconhecidamente fundamental no trabalho de proteção integral a crianças e adolescentes. Quando há necessidade de afastamento da família, os esforços devem acontecer para que a reintegração se dê no menor tempo possível e, especialmente, para que as referências familiares não sejam perdidas. Para tanto, deve-se buscar o fortalecimento e a manutenção dos vínculos afetivos entre os abrigados e sua família.

Além do fortalecimento e da manutenção dos vínculos afetivos entre os abrigados e seus familiares, outro aspecto se mostra importante para a garantia do direito à convivência familiar das crianças e dos adolescentes em abrigos: a busca da reestruturação de suas famílias. Assim, pais, mães e responsáveis poderão desenvolver as condições para receber seus filhos de volta, superadas as dificuldades que determinaram o afastamento.

Cabe aos profissionais não apenas dar suporte aos pais, enfatizando-se aqui a mãe como principal agressora, e mostrá-los a importância de responderem construtivamente diante de uma situação de violência, mas também ajudá-los a desenvolver habilidades para enfrentar situações, evitando atos violentos. É indicado incentivar respostas protetoras que ampliem seu suporte social e reduzam estratégias contraproducentes - por exemplo, negação do problema, aumento do uso de álcool e drogas, dentre outras (KASSAM-ADAMS; FEIN, 2003). Pesquisas demonstram que o fortalecimento das respostas das famílias é um método eficiente para reduzir traumas nas vítimas (LOVETT, 2004).

Acreditamos ser importante um trabalho junto aos agressores, que também requerem serem cuidados, ajudando-os a encontrar caminhos para que recuperem sua dignidade e respeitabilidade particularmente no contexto da violência intrafamiliar. 
Nesta direção é que propomos esta pesquisa que focaliza a mulher/mãe usuária de álcool e drogas, como cuidadora e agressora de seus filhos, buscando compreender suas ambiguidades e os motivos da agressão. 


\section{Objetivos}

\subsection{Geral}

- Compreender como mães usuárias de álcool e drogas significam a violência perpetrada junto aos seus filhos, tendo por base seu contexto histórico e social.

\subsection{Específicos}

- Traçar o perfil das mães usuárias de álcool e drogas que manifestam atos de violência contra seus filhos (crianças e adolescentes);

- Identificar determinantes da violência na história de vida destas mães, no contexto das relações sociais intrafamiliares, em que se constroem as identidades femininas e maternas;

- Identificar o significado da maternidade e como a violência se apresenta no cuidado materno. 


\section{Marco Teórico Conceitual}

\subsection{Dimensão conceitual da violência contemporânea e políticas de controle e proteção a grupos vulneráveis - crianças e adolescentes}

A violência é uma questão que permeia a condição humana. Sua visibilidade tanto pode ser relacionada às formas pelas quais se manifesta, quanto à capacidade da sociedade em percebê-la efetivamente. Faz parte da chamada questão social, relacionada a formas de dominação e opressão desencadeadoras de conflitos. É considerada um fenômeno complexo, polissêmico e controverso, praticada por indivíduos contra outros indivíduos, manifestando-se de várias maneiras, assumindo formas diversas de relações pessoais, sociais, políticas ou culturais (BRASIL, 2001a; OMS, 2002; RIBEIRO; FERRIANI; REIS, 2004).

O conceito de violência é culturalmente construído, ou seja, está intimamente ligado a um processo histórico-cultural, o que não descaracteriza a violência do ato, mas enfoca a violência a partir da cultura em que está inserida (GOMES et al., 2002).

Quando a violência é uma forma de relação que se estabelece no interior das famílias ou na convivência social, é preciso denunciá-la e desnaturalizá-la, tratando-a como um problema a ser resolvido, buscando formas "civilizadas" de trabalhar com os conflitos. Nunca é demais lembrar que os conflitos são normais e até desejáveis na sociedade, pois indicam a pluralidade de visões, de desejos e projetos. O mal, portanto, não está em expressá-los, mas em suprimir a oportunidade do debate, do diálogo e do exercício da tolerância. No caso das crianças e dos adolescentes, geralmente os pais, responsáveis e adultos tendem a acabar com as divergências de idéias e de comportamentos e com o conflito de gerações, por meio da dominação adultocêntrica, da imposição de sua vontade, ou por meio de gestos e ações violentos. (BRASIL, 2002) 
A violência intrafamiliar, tratada nessa pesquisa, é definida de acordo com Day et al. (2003), os quais entendem por violência intrafamiliar toda ação ou omissão que prejudique o bem-estar, a integridade física, psicológica ou a liberdade e o direito ao pleno desenvolvimento de um membro da família. Pode ser cometida dentro e fora de casa, por qualquer integrante da família que esteja em relação de poder com a pessoa agredida. Inclui também as pessoas que estão exercendo a função de pai ou mãe, mesmo sem laços de sangue.

Conforme o Ministério da Saúde (BRASIL, 2001b, p. 15), o conceito de violência intrafamiliar "não se refere apenas ao espaço físico no qual a violência ocorre, mas também às relações no qual se constrói e efetua". Além disso, coloca que a prevalência significativa da violência intrafamiliar constitui sério problema de saúde, grave obstáculo para o desenvolvimento social e econômico e uma flagrante violação aos direitos humanos. Minayo (2002) e Silva et al. (2002) também colocam que a violência intrafamiliar representa um importante fator de impedimento para o adequado desenvolvimento e integração social de crianças e adolescentes, em consequência dos traumas físicos e psicológicos, durante sua trajetória de vida.

Segundo Reichenheim, Dias e Moraes (2006) a violência intrafamiliar é resultado de características individuais, contextuais e ambientais. A conjunção de características implica em uma variação na frequência da violência seja conjugal ou contra filhos. Neste sentido, a idade, o estado civil ou a personalidade de indivíduos; hábitos de vida como o abuso de álcool e drogas ilícitas; a inserção social da família envolvendo baixa renda, pouca escolaridade e desemprego; ou ainda o papel de gênero nas relações familiares - quer presentes, quer históricas nas famílias de origem - se constituem de características importantes de serem consideradas.

Concordamos com Sacramento e Rezende (2006, p.101) quando se referem à violência intrafamiliar através de uma análise mais complexa: 
Estudos apontam que a violência nas relações familiares envolve atos, palavras e pensamentos que depreciam a imagem da pessoa diante de si e dos outros. Os sentimentos que vão se formando afetam a vida psíquica da vítima. O desenvolvimento de feridas emocionais, criadas a partir dos relacionamentos agressivos, onde a pessoa é vítima de violência pode ficar registrado em seu psiquismo como marcas traumáticas. Muitas situações ocorridas nesses lares não são objeto de boletins de ocorrência, pois são assuntos de família e, segundo as Leis Domésticas, só devem ser abordados na intimidade da mesma.

É importante colocar que a violência intrafamiliar apresenta-se por meio de quatro manifestações principais: violência física, violência psicológica, abuso sexual e negligência, tendo sido encontrado também o abandono, como consequência extremada da negligência. Os conceitos dessas manifestações são abordados a seguir.

Violência física é cometida quando uma pessoa, que está em relação de poder à outra, causa ou tenta causar dano não acidental, por meio do uso da força física ou de algum tipo de arma, que pode provocar - ou não - lesões externas, internas ou ambas (ALGERI; SOUZA, 2006), impingindo-lhe desde a dor até a morte, para disciplinar ou tão somente expressar desafeto (BAZON, 2008). Segundo concepções mais recentes, o castigo repetido, não severo, também é considerado como violência física (BRASIL, 2001a).

Violência psicológica evidencia-se como a interferência negativa, conformando um padrão de comportamento abusivo, minando a autoestima ou senso de realização da criança e/ou adolescente. As formas mais comuns são: rejeitar, isolar, aterrorizar, ignorar, corromper e criar expectativas irreais ou extremadas sobre o indivíduo (ALGERI; SOUZA, 2006; BAZON, 2008). Essa forma de violência causa dano no psiquismo da criança, impedindo o desenvolvimento sadio (COLLET; OLIVEIRA, 2002). Castro Neto (1994) afirma que “o abuso emocional não vem acompanhado de hematomas, mas pode ser pior do que o abuso físico".

Violência sexual é entendida por Deslandes (1994a) como todo ato ou jogo sexual, seja em relação hetero ou homossexual, cujo agressor está em estágio de desenvolvimento psicossexual mais adiantado que a 
vítima, com objetivo de estimulá-la sexualmente ou utilizá-la como meio para alcançar satisfação sexual. Araújo (2002) afirma que o abuso sexual é um fenômeno complexo e difícil de enfrentar por parte de todos os envolvidos, pois muitas vezes os profissionais não sabem que decisão tomar diante do problema.

Castro Neto (1994) evidencia que o abuso sexual e o incesto não são tabus. O verdadeiro tabu é falar sobre esses temas. A autora ressalta que devemos desvendar o abuso sexual, o qual atinge crianças e adolescentes de todas as idades, que, na maioria das vezes, não envolve violência física, mas se dá de modo insidioso. Ferreira e Cartana (2003) consideram que a violência sexual interrompe a maturação sexual normal da criança, desenvolvendo nela uma sexualidade prematura e falha, pois ela recebe através do abuso uma concepção errada de sexualidade.

Negligência é explicada como a omissão da família em prover as necessidades físicas e emocionais de uma criança ou adolescente. Manifesta-se quando os pais ou responsáveis falham em alimentar, vestir adequadamente, medicar ou educar seus filhos em circunstâncias em que poderiam fazê-lo (CAMARGO; BURALLI, 1998). Os acidentes também podem ser classificados como um dos tipos de negligência, uma vez que são passíveis de prevenção e resultantes do descuido dos responsáveis (ASSIS et al., 2004).

No Brasil, a violência contra crianças e adolescentes está conceituada pelo Ministério da Saúde, que adotou terminologias e definições oficializadas nos documentos da Política Nacional de Redução da Morbimortalidade por Acidentes e Violência e Notificação de MausTratos Contra Crianças e Adolescentes (BRASIL, 2002). O primeiro documento revela que

os acidentes e as violências resultam de ações ou omissões humanas e de condicionantes técnicos e sociais. Ao considerar que se trata de fenômeno de conceituação complexa, polissêmica e controversa, este documento assume como violência o evento representado por ação ou omissão realizadas por indivíduos, grupos, classes, nações, que ocasionam danos físicos, emocionais, morais e espirituais a si próprio ou aos outros (BRASIL, 2001b, p.7). 
Segundo Westphal (2002), os tipos de violência contra a criança e o adolescente são Violência Estrutural, Violência Infanto-Juvenil e Violência Doméstica. Elas se subdividem caracterizando cada tipo, pois devido às suas características variadas, a violência pode aparecer de diversas formas e faces e surgem na sociedade por meio de ações que se interligam, interagem e se fortalecem, possuindo como expressão concreta, os diferentes meios e métodos de coerção e dominação utilizados com a finalidade de conquistar, reter poder ou obter privilégios (RIBEIRO; FERRIANI; REIS, 2004).

A violência estrutural subdivide-se em três grupos e baseia-se fundamentalmente na estrutura social em que vivem as crianças e adolescentes: meninos e meninas de rua, nessa situação devido à falta de condições da família em mantê-los e também em função dos conflitos e violências no interior de suas famílias; meninos e meninas trabalhadoras, segundo o IBGE (2007), no Brasil, 7,5 milhões de adolescentes entre 10 e 17 anos trabalhavam, mantendo-se em torno dos 7 milhões em 19972008, a maioria destes empregados em trabalhos informais, ganhando muito abaixo do ideal (CASTRO; ABRAMOVAY, 2002); crianças e adolescentes institucionalizados, cujas instituições e reformatórios presentes no país voltam-se para a formação de uma personalidade rígida e dependente. Alexandre e Vieira (2004) observaram o comportamento de crianças institucionalizadas e verificaram que, quando em situação de abrigo, formam relações de apego umas com as outras e que a rede de apoio social representa um importante aspecto na resiliência destas crianças. Entretanto, para $o$ adolescente que se encontra em reformatórios, a própria sociedade o vê como uma ameaça, pois são definidos coletivamente como desviantes; aparece uma nova categoria de problema social, encadeando um processo de intervenção empreendido para selecioná-los, identificá-los e tipificá-los (LIMA, 1999).

Qualquer reflexão teórico-metodológica sobre a violência pressupõe o reconhecimento de sua complexidade, polissemia e controvérsia (MINAYO; SOUZA, 1998), tornando-se premente 
compreender que, ao ser perpetrada por indivíduos, grupos e/ou instituições, ela pode se manifestar de múltiplas maneiras, inclusive as dissimuladas e ideologizadas, assumindo diferentes papéis sociais, sendo desigualmente distribuída, culturalmente delimitada e reveladora das contradições e formas de dominação. Agindo com este intuito, Boulding (1981, p. 267) afirma que:

O conceito de violência estrutural, que oferece um marco à
violência do comportamento, se aplica tanto às estruturas
organizadas e institucionalizadas da família como aos sistemas
econômicos, culturais e políticos que conduzem à opressão de
determinadas pessoas a quem se negam vantagens da sociedade,
tornando-as mais vulneráveis ao sofrimento e à morte. Essas
estruturas determinam igualmente as práticas de socialização que
levam os indivíduos a aceitar ou a infligir sofrimentos, de acordo
com o papel que desempenham.

Compreender a violência estrutural no contexto social significa elucidar, a partir da ampliação e desenvolvimento deste raciocínio, os mecanismos pelos quais o Estado, em seus diferentes níveis e poderes, restringe o acesso da grande maioria da população aos direitos básicos que Ihe proporcionariam uma vida digna, gerando assim um grave quadro de exclusão social.

A violência infanto-juvenil - assim denominada por Westphal (2002) - também caracterizada como violência delinquencial por Sanchez e Minayo (2006), está articulada à violência estrutural e fundamenta-se na violência praticada pelas crianças e adolescentes e nas consequências sobre eles dessa realidade. A maioria dos infratores encontra-se em plena adolescência e, destes, grande parte já vivenciou desde a infância a ausência da mãe no lar, distanciamento do pai, relacionamentos familiares tensos, agressões físicas, emocionais e abandono. Numa sociedade desigual como a brasileira, essa situação precisa ser analisada atrelada à violência estrutural e à questão de classe, pois a maioria dos que estão em regime de medidas sócio-educativas são jovens pobres.

A violência doméstica, por sua vez, inclui membros sem função parental, que convivem no espaço doméstico. Incluem-se aí empregados 
(as), pessoas que convivem esporadicamente e agregados (BRASIL, 2001a).

Minayo e Souza (2003) afirmam que o indivíduo em sua complexidade e dinamicidade está envolvido na situação de violência, contudo, é importante considerar que a violência é social e historicamente construída. A violência não é o ato de delinquência, mas o resultado de um processo cultural crescente de desvalorização do ser humano, da vida, das relações. É uma questão política, histórica e eminentemente social, bem maior do que a especificidade individual de quem pratica violência.

Portanto, a força, a coerção e o dano em relação ao outro - ato de excesso presente nas relações de poder, tanto nas estratégias de dominação ao nível macro quanto nas redes de micropoder entre os grupos sociais - caracterizam a violência social contemporânea.

Embora a violência seja um fenômeno que tenha sempre feito parte da experiência humana, a cada ano seu impacto é sentido por milhões de pessoas, com altos custos na forma de sofrimento, dor, mortes, além das perdas materiais.

Diante desta realidade, medidas de proteção a grupos vulneráveis, tais como crianças e adolescentes, e controle das consequências da violência foram tomadas nos últimos anos.

A Declaração Universal dos Direitos das Crianças da ONU de 1959 inaugura uma nova forma de pensar a criança e o adolescente, dando-Ihes um tratamento diferenciado e prioritário por serem seres humanos em desenvolvimento. Surge assim a doutrina da proteção integral. O menor deixa de ser objeto de direitos e transforma-se em sujeito de direitos, tendo acesso irrestrito e privilegiado à Justiça. A proteção deixa de ser obrigação exclusiva da família, e o Estado e a sociedade passam a ser igualmente responsáveis pela tutela dos direitos da criança e do adolescente.

Apesar de a Declaração ser de 1959, o Brasil só a efetivou com a promulgação da Constituição de 1988 e posteriormente com o Estatuto da Criança e do Adolescente (ECA) em 1990. A Carta Magna impõe o dever à 
família, ao Estado e à sociedade de assegurar à criança e ao adolescente, com absoluta prioridade, o direito à vida, à saúde, à alimentação, à educação, ao lazer, à profissionalização, à cultura, à dignidade, ao respeito, à liberdade e à convivência familiar e comunitária, além de colocá-los a salvo de toda forma de negligência, discriminação, exploração, violência, crueldade e opressão (BRASIL, 1990).

Reconhecemos esse grupo socioetário como sujeito de direitos, modificando toda uma legislação anterior que considerava meninos e meninas como propriedades de seus pais. O ECA passou a ter força de lei, criando as pré-condições para que meninos e meninas fossem criados de forma mais saudável e respeitosa.

A Constituição Federal de 1988 inova na proteção à criança e ao adolescente ao adotar a doutrina da proteção integral, diferenciando da doutrina da situação irregular vigente até então com o Código de Menores (BRASIL, 1988). A doutrina da situação irregular tinha como objeto legal apenas os menores de 18 anos em estado de abandono ou delinquência, sendo submetidos pela autoridade competente às medidas de assistência e proteção.

Vale considerar que, pelo Código de Menores de 1979, vulgarmente conhecido como um Código Penal para menores propunha-se somente a repressão de crianças e adolescentes em situações patológicas e, apenas nestas situações, o Poder Judiciário poderia ser acionado. O acesso à Justiça era limitado aos menores nas situações previamente taxadas no art. II do Código de Menores e os demais eram excluídos da proteção jurídica. A lei não assegurava especificamente às crianças e aos adolescentes direitos fundamentais, mas sim à família, à qual cabia a obrigação de tutela dos menores. Segundo esta concepção, a responsabilidade sobre o menor era exclusiva da família, abstendo-se o Estado e a sociedade de qualquer dever (BRASIL, 1980).

O ECA veio ao encontro da Constituição Federal e logo em seu primeiro artigo enfatiza a proteção integral da criança e do adolescente. $\mathrm{O}$ artigo $3^{\circ}$, por considerar os menores pessoas em desenvolvimento, 
assegura-Ihes todas as oportunidades e facilidades "a fim de lhes facultar o desenvolvimento físico, mental, moral espiritual e social, em condições de liberdade e de dignidade" (BRASIL, 1990).

A aprovação do ECA possibilitou a esse segmento da sociedade ser juridicamente considerado "sujeito de direitos, e não mais menores incapazes, objetos de tutela, de obediência e submissão", representando relevante avanço na conquista dos direitos humanos (BRASIL, 2004, p. $67)$.

A grande vantagem de se enunciar direitos é que esses passam a ser exigíveis. Surge a possibilidade de acionar o aparato estatal diante da ameaça de qualquer direito assegurado pela Constituição e/ou pelo ECA. O Estatuto prevê instrumentos para a efetivação destes direitos, como: a possibilidade de varas especializadas da infância e juventude nos Estados e no Distrito Federal; a intervenção obrigatória do Ministério Público nos procedimentos em que não for parte; políticas públicas voltadas para a criança e o adolescente; os Conselhos Nacionais, Estaduais e Municipais dos Direitos da Criança e do Adolescente e os Conselhos Tutelares.

Através dos Conselhos Tutelares e dos Conselhos da Criança e do Adolescente instrumentalizaram-se mecanismos para que a sociedade possa participar da elaboração de políticas públicas voltadas para a criança e o adolescente e da fiscalização dos direitos e garantias assegurados pelos dispositivos legais. Um aspecto relevante a ser ressaltado são os mecanismos estabelecidos pelo ECA para assegurar a autonomia do Conselho Tutelar e a existência do Conselho de Direitos. Ao primeiro, a lei municipal que o cria deverá dispor sobre os recursos que Ihe serão destinados. Ao segundo, o ECA condiciona o repasse Federal dos recursos referentes aos programas e atividades à existência dos Conselhos de Direitos.

O fato de os Conselhos Tutelares e de Direitos serem compostos por membros eleitos pela comunidade significa a participação direta da sociedade na fiscalização e solução dos seus próprios problemas. Isto se 
mostra importante, uma vez que não há ninguém melhor que os próprios membros da comunidade ou Organizações da Sociedade para deliberarem quais os principais problemas relacionados à infância e à juventude, traçarem metas, solucioná-los e aplicar medidas protetivas.

Os Conselhos Tutelares são encarregados pela sociedade de zelar pelo cumprimento dos Direitos da Criança e do Adolescente. São compostos por cinco membros diretamente eleitos pela comunidade para um mandato de três anos; gozam de autonomia; são permanentes, nãojurisdicionais e independentes.

A autonomia consiste no fato de o Conselho não necessitar de ordem judicial para aplicar e decidir as medidas protetivas (são exemplos: encaminhamento aos pais e responsável, mediante termo de responsabilidade; orientação, apoio e acompanhamento temporários; abrigo em entidade; requisição de tratamento médico, psicológico, psiquiátrico, em regime hospitalar ou ambulatorial). Sua independência é relativa, pois é submetido à fiscalização do Conselho Municipal de Direitos, do Ministério Público, da autoridade judiciária, das entidades civis que trabalham com a população infanto-juvenil (BRASIL, 1990).

As atribuições dos Conselhos Tutelares são voltadas para a solução dos problemas que atingem a criança e o adolescente de uma determinada cidade ou região. Para tanto, o Estatuto prevê uma série de medidas a serem adotadas pelos Conselhos, tais como: atender crianças e adolescentes que tiveram os direitos violados ou ameaçados; aplicar medidas de proteção; atender ou aconselhar pais ou responsáveis; encaminhar à autoridade judiciária os casos de sua competência; requisitar serviço público nas áreas de saúde, educação, previdência, trabalho e segurança, entre outros.

O Conselho Nacional de Direitos da Criança e do Adolescente (CONANDA) é outro órgão composto por membros da sociedade civil e tem como finalidade a deliberação e o controle das ações governamentais em todas as questões relativas ao atendimento dos direitos da criança e do adolescente. Está presente em esferas municipal, estadual e federal. 
Cabe a ele não somente traçar diretrizes, mas também, detalhar e fiscalizar a execução, por parte do Poder Executivo, das políticas por ele deliberadas (CONANDA, 2000).

A descentralização e participação promovida pelo ECA é um exemplo bem sucedido da aplicação do princípio participativo presente na Constituição Federal. A população, envolvida em solucionar seus problemas, reivindicar seus direitos e deliberar sobre as políticas sociais que os beneficiam é um elemento fundamental na construção do sonho democrático de 1988.

Todavia, até 2004, cerca de 1800 municípios brasileiros ainda não possuíam Conselhos Tutelares e em 1200 não foram estruturados os Conselhos de Direitos. Estes dados, da Secretaria Especial dos Direitos Humanos, mostram que a efetivação dos direitos previstos no ECA encontram uma barreira na falta de vontade política, no clientelismo, no fisiologismo, na burocracia do governo e no conformismo do povo, como também na escassez de verbas destinadas ao cuidado com as crianças e jovens do nosso país.

Apesar dos entraves considerados, é importante destacar que o ECA é um avanço na direção do reconhecimento dos direitos de crianças e adolescentes, possibilitando a construção de uma nova cultura das relações adulto-jovens, baseadas no afeto, proteção e socialização. Assim, essa nova cultura implica também denúncia e responsabilização dos violadores desses direitos (BRASIL, 2004, p. 67).

O ECA, o Código de Ética Médica e o Código Civil exigem que se denuncie ao Conselho Tutelar suspeitas ou casos concretos de violência intrafamiliar contra criança ou adolescente. Goes (2002) alerta que os dados epidemiológicos não são confiáveis. Ressalta que, segundo estimativas, para cada caso notificado, dez não o são. Por essa razão, ele relembra o compromisso dos profissionais da saúde diante de qualquer suspeita de vitimização.

Nesta direção, nos últimos anos, trabalhadores da saúde pública, pesquisadores e os próprios sistemas de saúde têm investido esforços e 
recursos no sentido de compreender as raízes da violência e controlar suas consequências (OMS, 2002).

$\mathrm{Na}$ busca de compreender a violência, a OMS desenvolveu uma tipologia deste fenômeno e reconheceu três grandes categorias referentes a quem comete atos violentos de maneira geral, a saber:

- Autoinfligida: suicídio, auto-abuso;

- Interpessoal: familiar, parceiros íntimos, entre indivíduos da comunidade, juvenil, na escola e estupro por estranhos;

- Coletiva: cometida por grupos maiores de indivíduos ou por estados e nações para ganhar, romper, perturbar atividades econômicas, entre outras (OMS, 2002).

Na Assembleia de 1996, a OMS declara a violência como o maior e mais crescente problema de saúde pública e lança a Resolução 49.25, contendo propostas que visam reduzir o impacto e prevenir a violência ao redor do mundo (OMS, 2002).

Inserido neste movimento global, o Brasil, no ano de 1998, iniciou, através do Ministério da Justiça, a implementação do Programa Nacional dos Direitos Humanos, com a Campanha "Não à Violência, um Direito Nosso", distribuindo material e promovendo interlocuções entre os órgãos responsáveis, Organizações Não-Governamentais (ONGs), universidades e sociedade civil, para despertar a consciência de que a responsabilidade de proteger a humanidade e prevenir este mal é de todos.

A lentidão em reconhecer o problema, a utilização de diferentes definições sobre o fenômeno pelas instituições e pesquisadores, a diversidade das fontes de informação, a inexistência de inquéritos populacionais nacionais e a dificuldade de captar seus efeitos pelos profissionais são alguns dos fatores que dificultam estimativas mais acuradas. Dessa maneira, no Brasil, como em outros países, a magnitude da violência ainda não pode ser dimensionada, inclusive a da violência intrafamiliar. 
Apenas recentemente o Brasil dispõe de alguns dados reunidos pelo Programa Sentinela. Este é um programa concebido pelo Ministério da Previdência e Assistência Social, mas atualmente está sob a responsabilidade do Ministério do Desenvolvimento Social e Combate à Fome. Ele constitui um esforço do governo federal para enfrentar a questão do abuso e exploração sexuais de crianças e adolescentes, através da política social. Tendo iniciado suas atividades em 2001, atualmente existem apenas 5,95\% dos municípios do país - 331 municípios - conveniados com o Programa Sentinela. Embora este programa seja direcionado às vítimas de violência sexual, acabou atendendo os outros tipos, porque, em geral, um tipo de violência não acontece isoladamente, ele se faz acompanhar de outro ou outros tipos também. Por exemplo, a violência sexual sempre impõe à vítima a violência psicológica, paralelamente. Através de uma pesquisa postal, verificou-se que, no ano de 2003, o Programa Sentinela atendeu 19.245 casos de violência. Todavia, deste total, 9.990 casos eram de outros tipos de violência na família contra criança e adolescente e, somente os outros 9255 eram especificamente de violência sexual (BRASIL, 2004).

A violência contra crianças e adolescentes é uma realidade dolorosa, responsável por altas taxas de mortalidade e de morbidade nessa faixa etária. Isso exige uma resposta séria e urgente da sociedade. Os serviços de saúde não podem deixar de enfrentar, ao lado de outros setores governamentais e não-governamentais, esse grave problema, que hoje faz parte da agenda de saúde pública de vários países.

\subsection{A construção social da mulher para a maternidade e o movimento de proteção a infância}

Acreditamos que a maternidade é um construto social que orienta as práticas e os afetos dos sujeitos sociais. A partir de noções 
socialmente construídas do que é ser mãe, são orientadas as relações sociais entre mãe e filho, assim como a própria identidade de ser mulher (SAMPAIO; SANTOS; SILVA, 2008).

Contemporaneamente, em nossa sociedade, a maternidade continua sendo afirmada como um elemento muito forte da cultura e identidade feminina. Refere Scavone (2004) que as relações das mulheres com as características biológicas da maternidade ocorrem em determinados momentos - gravidez, parto, amamentação - em que o cultural e o natural se cruzam.

O que hoje se considera como um bom referencial de mãe é bastante discordante do que se concebia, por exemplo, na Europa, nos séculos XVII e XVIII. Alguns comportamentos maternos considerados naquela época normais, corretos e esperados seriam algo anormal, incorreto e incompreensível no contexto de várias sociedades contemporâneas (AZEVEDO; ARRAIS, 2006).

Por isso, a prática materna valorizada deve ser compreendida dentro de um contexto sociocultural, e não sob a ótica de uma suposta determinação biológica para o desejo e o desempenho da maternidade. Dessa forma, como entender valores maternos tão diferentes nos diversos momentos da História?

As contribuições de autores como Badinter (1988) e Ariès (1986) permitem a reconstrução da trajetória histórica da significação dos cuidados maternos. Badinter (1988) parte das produções simbólicas construídas desde o século XIX pelas sociedades européias, mais precisamente a francesa, no seu processo de urbanização, demonstrando como questões de ordem social interferem na construção do que se compreende por amor materno. O conceito de maternidade está intrinsecamente relacionado com várias representações sociais, dentre elas as de criança, família, mulher e cuidado.

Segundo Giddens (1993), a "invenção da maternidade" faz parte de um conjunto de influências que afetaram as mulheres a partir da final do século XVIII e guarda relação com o movimento de reconhecimento do 
valor social da criança e a necessidade de criar medidas para proteção e de sobrevivência infantil.

Anteriormente, as crianças eram consideradas seres de menor importância. Era de aceitação comum na sociedade o abandono, a negligência, o sacrifício e a violência contra crianças, chegando ao filicídio, declarado ou velado, que levava as taxas de mortalidade infantil, na França do século XVIII, a níveis absurdos, inacreditáveis, sempre maiores que $25 \%$ das crianças nascidas vivas.

Segundo Ariès (1986) até meados do século XII, na Europa, a infância não tinha a significação que foi adquirindo ao longo do tempo. Analisando a produção artística medieval, o autor observou que as crianças não eram representadas como tal, em suas características físicas peculiares, mas sim como adultos em menor escala. A interpretação proposta pelo autor é de que a infância não tinha grande importância social para a sociedade da época. Na idade média, a mortalidade infantil apresentava altos índices, o que pode explicar, de certa forma, a indiferença com que a infância era tratada.

Retrato desta indiferença é apresentado por Badinter (1988) sobre a sociedade francesa antes do século XVIII. Segundo a autora, raramente uma criança era amamentada ao seio da mãe e cerca de dois terços delas morriam junto às amas de leite - miseráveis e mercenárias - contratadas pela família e nas casas das quais ficavam, em média, quatro anos, quando sobreviviam. Havia mães que elegiam um dos filhos para criar consigo e entregavam os outros às amas ou a outras famílias. Nas camadas mais abastadas era comum as mulheres recusarem-se a amamentar seus filhos para não terem que se retirar de sua vida social, a fim de não "estragar" o corpo e mesmo para não se aborrecerem com as necessidades da criança. Era comum também as mães não comparecerem aos enterros de filhos com menos de cinco anos, algumas vinham a saber da morte do filho muito tempo depois de ela ter acontecido, pois estes viviam com as amas de leite e as famílias não mantinham contato ou se 
preocupavam em acompanhar, mesmo que a distância, o desenvolvimento das crianças.

Nos asilos de Paris, mais de $84 \%$ das crianças abandonadas morriam antes de completar um ano de vida, prática que se estendeu no século XIX, quando ainda era comum o abandono de filhos na roda dos expostos.

A criança passou a ser protegida por interesses, antes de tudo econômicos e políticos, a partir da Revolução Industrial, especialmente em fins do século XVIII. A criança, até então estorvo inútil - porque nada produzia - passou a ser valorizada, sob a óptica de que deveria sobreviver para se tornar um adulto produtivo. As sociedades protetoras da infância surgiram na Europa entre 1865 e 1870, e eram mais recentes e menos representativas do que a Sociedade Protetora dos Animais. A palavra pediatria só surgiu em 1872. De acordo com Badinter (1988), os médicos, até então, não tratavam as crianças. Achavam que isso era tarefa das mulheres, ou seja, das mães e amas. Em resumo, apesar de ainda não respeitada na sua individualidade, a criança começou a ser de alguma forma protegida há pouco mais de cem anos.

Já no século anterior, século XVII, os retratos de crianças sozinhas ou de famílias organizadas em torno das crianças foram se tornando mais comuns. A criança com suas características peculiares estava começando a despertar um novo sentimento da infância quando os adultos passaram a admirá-la, "paparicá-la" e até se divertir com ela. Essa "paparicação" despertou também outro sentimento nos que não compartilhavam daquele e se preocupavam com o disciplinamento das crianças - entre eles estavam os eclesiásticos, os moralistas e os homens da lei - as suas preocupações com relação à disciplina e educação das crianças foram assumidas pelas famílias, assim como os cuidados com a saúde e com o corpo.

Assim, ao colocar a criança em um lugar central da família, a sociedade construiu um sentimento novo: o sentimento de família; mesmo já existindo, as famílias orientavam-se por outras lógicas sociais 
como a linhagem, a sucessão dos bens ou hierarquias ou a integridade do patrimônio. A partir desse novo sentimento, diretamente relacionado ao sentimento da infância, a família passou a ser reconhecida como um valor que viria a ser exaltado com grande emoção. Essa família referia-se à família conjugal - formada pelos pais e seus filhos, sem incluir os demais parentes.

O sentimento de família que foi se desenvolvendo alterou também a relação dos pais com os filhos, que se estabelecia a partir da ordem do nascimento ou do sexo. Os filhos passaram a ser tratados com mais igualdade no direito à herança, pois antes o tratamento era de privilégios ao primogênito, desde que fosse do sexo masculino. Essa maior aproximação com todos os filhos contribuiu para reforçar a família conjugal, que foi se organizando de forma a valorizar uma maior privacidade e intimidade doméstica. A vida privada passa a ser valorizada e distanciada do espaço público. Se antes as coisas aconteciam de forma misturada, agora havia uma importante separação entre os espaços públicos e privados (BOCK, 2001). O costume de entregar os bebês para serem amamentados por amas de leite, no entanto, perdurou até o século XIX.

Com o desenvolvimento do sentimento de família, o foco que até então se direcionava à figura do pai passa a valorizar o papel da mãe. A importância da autoridade paterna e a submissão da mulher e dos filhos a essa autoridade vão dando lugar a uma exaltação do amor materno construindo novas formas de interação e de relações de poder dentro da família. A nova ordem econômica que passa a vigorar com a ascensão da burguesia reforça a importância da sobrevivência das crianças e, como consequência, a exaltação do amor materno (MOURA; ARAÚJ O, 2004).

Surge um novo amor pela criança, muito mais reforçado pelo contato físico, pela vivência das trocas afetivas e pelo testemunho dos benefícios visíveis dessa aproximação. O discurso que dá sustentação à manutenção dessa relação é masculino, a forma de concebê-la tem raízes utilitaristas, de controle social e econômico, no entanto, a oportunidade 
dada a mães e aos filhos foi fundamental para construção desse novo amor materno (BADINTER, 1988).

A necessidade de a mulher encarregar-se dos cuidados com os filhos foi reforçada pelo discurso dos médicos, moralistas, administradores e chefes de polícia. A idéia difundida foi que, uma vez que só a mulher poderia dar à luz, seria "natural" que coubesse a ela o cuidado com os filhos. A relação específica entre mãe e filho era bem diferente da que se construiu através desses discursos. O comportamento materno que se constrói sob a idéia de que os cuidados e carinho da mãe eram insubstituíveis para sobrevivência e conforto do bebê, estava tomando força e prometia grande satisfação pessoal para a mãe assim como reconhecimento de seu valor perante a sociedade. A mulher passava a ter uma importância social, como mãe, que não existia antes.

Nesse período, destaca-se a forte associação da maternidade com a feminilidade. Esse modelo consolidou-se em uma ideologia que passou a exaltar o papel natural da mulher como mãe, atribuindo-lhe todos os deveres e as obrigações na criação dos filhos e limitando a função social feminina a realização da maternidade (SCAVONE, 2004).

Os discursos foram complementando-se e direcionando a mulher para a vida doméstica, oferecendo-Ihe um espaço de poder dentro da família, garantindo as possibilidades de manter a mão de obra masculina produzindo e, em longo prazo, garantindo uma formação de mão-de-obra pelo modelo de família que veio a ser assumido pelas mães. O desenvolvimento da economia da sociedade industrial estava garantido.

No decorrer do século XIX, tornou-se uma necessidade para o capitalismo a inserção do trabalho feminino nas indústrias, o que oferecia uma mão-de-obra dócil e barata para operar as novas maquinarias. As diferenças que já existiam entre o discurso social da maternidade e as diferentes realidades vividas pelas classes sociais se intensificaram e um grande número de mulheres foi absorvido no processo de industrialização gerando um novo tipo de mães - as que trabalhavam fora de casa por longas jornadas diárias e ainda acumulavam todas as tarefas domésticas e 
maternais. A dificuldade extrema levou muitas mães trabalhadoras a perderem seus filhos por abandono ou morte.

A transição de um modelo tradicional de maternidade para um modelo moderno de maternidade deu-se com a consolidação da sociedade industrial. As mulheres vão, no decorrer do século $X X$, ocupar gradativamente o espaço público, ao mesmo tempo em que mantêm a responsabilidade na criação dos filhos. Segundo Scavone (2004), a maternidade como fenômeno social é marcada por desigualdades sociais, racial-étnicas e pela questão de gênero que the é subjacente. Consequentemente, as mudanças e implicações sociais da realização dessa experiência não atingem da mesma forma todas as mulheres, países e culturas, apesar de existir um modelo de maternidade preponderante nas sociedades ocidentais contemporâneas - proles reduzidas e mães que trabalham fora.

Conciliar um discurso idealizado de mãe com uma realidade social em que o trabalho era necessário ao sistema e às próprias mulheres levou, com a chegada do século XX, a um esquema protecionista da maternidade, traduzido em uma legislação que previa redução da jornada de trabalho, tarefas mais leves e licença maternidade. As tensões sociais continuavam direcionando o papel das mulheres...

Se a Primeira Guerra Mundial lembrou as mulheres das suas obrigações nas fábricas, sobretudo de munições, para substituir os homens, uma vez terminada a guerra lançou-se a seguinte palavra de ordem: 'Mulheres, para casa' (TUBERT, 1996, p.121).

Esse retorno da mulher à vida doméstica foi reforçado pelo desenvolvimento tecnológico pós-Revolução Industrial em que o culto às máquinas atingiria a vida doméstica e traria propostas de facilitar também a vida das mães e suas famílias. A partir desse entusiasmo, o sistema capitalista de produção reforçou seus alicerces e penetrou em todas as dimensões da vida das pessoas. O mercado consumidor se consolidou e necessidades foram atendidas e criadas. O contexto atual segue a lógica 
do consumo e do capital e as relações familiares são diretamente afetadas.

Novas relações familiares estão sendo construídas a partir da entrada da mulher no mercado de trabalho, fazendo com que homens e mulheres assumam novos papéis na dinâmica familiar. O processo de globalização e as mudanças histórico-sociais na relação mãe-filho introduzem novos questionamentos acerca dessa relação, culminando em importantes mudanças culturais com consequentes implicações sociais.

Para Cabral (1995), a maneira como a mãe atende às necessidades de seu filho é produto de um processo cumulativo de informações transmitidas na família de geração para geração. A via de transmissão de conhecimentos está permeada por uma rede que envolve cultura, contexto social, valores, sociedade e história.

Considerando os projetos e as possibilidades das mulheres no seu espaço social relacional, os estudos feministas, em seu primeiro momento, privilegiaram a maternidade para explicar a situação de desigualdade das mulheres em relação aos homens. Portanto, a recusa consciente da maternidade foi o caminho proposto pelo feminismo para alcançar a liberdade. Esta recusa consistia em uma tentativa de negar o fatalismo biológico feminino da maternidade, rompendo o determinismo dado pela natureza. Em um segundo momento, inspirada na psicanálise, recupera a maternidade como um poder insubstituível das mulheres, fazendo parte da história e identidade femininas e invejada pelos homens (SCAVONE, 2004). O problema não era mais a negação da maternidade, mas a divisão equitativa das responsabilidades entre mães e pais.

A este respeito, conforme observa Azevedo (2001), fatores como as relações de produção, a definição das relações de trabalho e sua divisão social sempre estiveram subjacentes à determinação cultural que elege a mulher como cuidadora. Considera Scavone (2004) que, apesar das mudanças ocorridas nos últimos tempos, o pai ainda continua responsável pelo sustento da família. A busca pela igualdade na 
responsabilidade parental, ainda está longe de ser alcançada em todos os seus aspectos, visto que pressupõe uma relação igualitária entre os sexos.

Nas relações hierárquicas historicamente persistentes entre homens e mulheres, a questão de gênero deve ser pensada não somente como uma relação entre homens e mulheres, mas como elemento constitutivo das relações sociais (TOLEDO, 2003).

Sorj (2005) observa que as desigualdades na sociedade foram superadas em alguns aspectos, no entanto, outras desigualdades ainda mantêm a sua legitimidade, por exemplo, a mulher tendo a função, perante a sociedade, de cuidar dos filhos - uma visão maternal enquanto o homem, perante a sociedade, tem a função de ser o provedor da manutenção do grupo familiar.

Com a incorporação das mulheres ao mercado de trabalho, na educação e na política, foi possível perceber uma miríade de mudanças nas relações de gênero. Contudo, verifica-se no mercado de trabalho que a relação de gênero mantém-se fortemente desigual, no âmbito da precarização das relações de produção vigentes, desdobrando-se em repercussões negativas de grande monta nas atividades femininas (SORJ, 2005).

A esta pluralidade de funções assumidas pela mulher na sociedade, um fenômeno tem-se mostrado presente em nosso meio: a condição da chefia feminina das famílias. Segundo Berquó (2001), as chefias femininas crescem no país como um todo, sendo um fenômeno tipicamente urbano - a maioria é do tipo monoparental. Destacam-se as mulheres mais jovens, separadas, negras, mais pobres e com baixo grau de escolaridade.

Neste momento, é relevante colocar a respeito da desigualdade dos rendimentos entre homens e mulheres. Em muitos casos, as mulheres estão concentradas em ocupações menos qualificadas e, nos casos em que desempenham tarefas igualmente qualificadas que os homens, as relações patriarcais e as desigualdades inerentes ao sistema social em curso tomam conta do cenário, reproduzindo no trabalho as relações 
hierárquicas vigentes no âmbito doméstico (TOLEDO, 2003; SOARES; OLIVEIRA, 2004).

O baixo rendimento das mulheres é considerado um suplemento da família, pois os rendimentos já seriam calculados para a própria subsistência e para a manutenção da família (SCOTT, 2001). O que se vivencia na atualidade é a crescente "feminilização da pobreza", precisamente com relação ao fenômeno recente do aumento das famílias chefiadas por mulheres, sejam esses domicílios chefiados por mulheres com ou sem companheiros (SPINDOLA, 2005).

A sobrecarga de atividades para as mulheres atrelada a condições sociais desfavoráveis podem resultar em dificuldade nos relacionamentos interpessoais, influenciando negativamente a interação entre mãe e filho.

Neste sentido é importante pensar nas relações intrafamiliares, particularmente naquelas que são estabelecidas entre mães e filhos, não mais a partir da especificidade de um determinismo natural da maternidade, a priori, mas variável de acordo com condições socioeconômicas e culturais de cada mulher, em que a maternidade pode ser compreendida em suas múltiplas formas de expressão.

$\mathrm{Na}$ variabilidade de expressão interessa-nos compreender o comportamento violento de uma mãe com um filho, o que em primeira instância se mostra como paradoxo frente ao ideário de ser mãe em nossa sociedade, que cuida, zela e protege o filho.

\subsection{A família e as dissociações dos papéis maternos como base à compreensão da violência intrafamiliar}

Em diferentes partes do mundo, a violência na família vem assumindo um crescente papel na morbimortalidade de mulheres, crianças e adolescentes (HEISE, 1994; MORAES; REICHENHEIM, 2002; ROSSMAN; 
HUGHES; ROSENBERG, 1999; STRAUS; GELLES, 1995; WATTS; ZIMMERMAN, 2002). Sua repercussão biopsicossocial tem fomentado um crescente interesse na elaboração de propostas de ação para prevenção, acompanhamento de vítimas e desenvolvimento de programas de investigação. No Brasil, há indicação de que a violência entre pais e filhos, um dos principais componentes da violência intrafamiliar, é um fenômeno expressivo, devendo ser encarada como prioridade na agenda dos diversos segmentos sociais (BRASIL, 1997, 2001a, 2002; DESLANDES; GOMES; SILVA, 2000).

A compreensão da violência intrafamiliar perpassa pelo conceito de família. A legislação brasileira vigente reconhece e preconiza a família, como estrutura vital, lugar essencial à humanização e à socialização da criança e do adolescente, espaço ideal e privilegiado para o desenvolvimento integral dos indivíduos (BRASIL, 2006b).

O termo família é derivado do latim famulus, que significa escravo doméstico. Este termo foi criado na Roma Antiga para designar um novo grupo social que surgiu entre as tribos latinas, ao serem introduzidas a agricultura e a escravidão legalizada. No direito romano clássico a família natural cresce de importância - esta família é baseada no casamento e no vínculo de sangue. A família natural é o agrupamento constituído apenas dos cônjuges e de seus filhos, tendo por base o casamento e as relações jurídicas dele resultantes entre os cônjuges, pais e filhos (ALVES, 1977).

Com a Revolução Francesa surgiram os casamentos laicos no ocidente e, com a Revolução Industrial, tornaram-se frequentes os movimentos migratórios para cidades maiores, construídas ao redor dos complexos industriais. Estas mudanças demográficas originaram o estreitamento dos laços familiares e as pequenas famílias, num cenário similar ao que existe hoje em dia. As mulheres saem de casa, integrando a população ativa e a educação dos filhos é partilhada com as escolas. Os idosos deixam também de poder contar com o apoio direto dos familiares 
nos moldes pré-Revoluções Francesa e Industrial, sendo entregues aos cuidados de instituições de assistência (MOREIRA, 2001).

Nessa altura, a família era definida como um "agregado doméstico (...) composto por pessoas unidas por vínculos de aliança, consanguinidade ou outros laços sociais, podendo ser restrita ou alargada" (MOREIRA, 2001, p. 22). Nesta definição, nota-se a ambiguidade motivada pela transição entre o período anterior às revoluções, representado pelas referências à família alargada, com a tendência reducionista que começava a instalar-se refletida pelos vínculos de aliança matrimonial.

Na cultura ocidental, uma família é definida especificamente como um grupo de pessoas de mesmo sangue, ou unidas legalmente (como no casamento e na adoção). Muitos etnólogos argumentam que a noção de sangue como elemento de unificação familiar deve ser entendida metaforicamente; dizem que em muitas sociedades e culturas nãoocidentais a família é definida por outros conceitos que não o de sangue. Poderia, assim, se constituir de uma instituição normalizada por uma série de regulamentos de afiliação e aliança, aceitos pelos membros. Alguns destes regulamentos envolvem: a exogamia, a endogamia, o incesto, a monogamia, a poligamia, e a poliandria (MOREIRA, 2001).

A família vem se transformando através dos tempos, acompanhando as mudanças religiosas, econômicas e sócioculturais do contexto em que se encontram inseridas. É um espaço sóciocultural que deve ser continuamente renovado e reconstruído; o conceito de próximo encontra-se realizado mais que em outro espaço social qualquer, e deve ser visto como um espaço político de natureza criativa e inspiradora.

Assim, a família deverá ser encarada como um todo que integra contextos mais vastos como a comunidade em que se insere. Ao encontro desta afirmação, Stanhope (1999, p.492) refere que a família é um "sistema de membros interdependentes que possuem dois atributos: comunidade dentro da família e interação com outros membros". 
Podemos, então, defini-la como um conjunto invisível de exigências funcionais que organiza a interação de seus membros, considerando-a, igualmente, como um sistema, que opera através de padrões transacionais. Assim, no interior da família, os indivíduos podem constituir subsistemas, podendo estes ser formados pela geração, sexo, interesse e/ou função, havendo diferentes níveis de poder, em que os comportamentos de um membro afetam e influenciam os outros membros. Como unidade social, a família enfrenta uma série de tarefas de desenvolvimento, diferindo a nível dos parâmetros culturais, mas possuindo as mesmas raízes universais (MINUCHIN,1990).

A família assume uma estrutura característica. Por estrutura entende-se, "uma forma de organização ou disposição de um número de componentes que se interrelacionam de maneira específica e recorrente" (WHALEY; WONG, 1989, p. 21). Deste modo, a estrutura familiar compõese de um conjunto de indivíduos com condições e em posições socialmente reconhecidas e com uma interação regular e recorrente, socialmente aprovada. A família pode, então, assumir uma estrutura nuclear ou conjugal, que consiste em um homem, uma mulher e em seus filhos, biológicos ou adotados, habitando um ambiente familiar comum. A estrutura nuclear tem uma grande capacidade de adaptação, reformulando a sua constituição, quando necessário.

Existem também famílias com uma estrutura de pais únicos ou monoparental, tratando-se de uma variação da estrutura nuclear tradicional devido a fenômenos sociais, como: divórcio, óbito, abandono de lar, ilegitimidade ou adoção de crianças por uma só pessoa.

A família ampliada ou extensa - também dita consanguínea - é uma estrutura mais ampla, que consiste na família nuclear, mais os parentes diretos ou colaterais, existindo uma extensão das relações entre pais e filhos para avós, pais e netos.

Para além destas estruturas, existem também as denominadas famílias alternativas, sendo elas as famílias comunitárias e as famílias homossexuais. 
As famílias comunitárias, ao contrário dos sistemas familiares tradicionais, em que a total responsabilidade pela criação e educação das crianças pertence aos pais e à escola; nestas famílias, o papel dos pais é descentralizado, sendo as crianças de responsabilidade de todos os membros adultos.

Nas famílias homossexuais existe uma ligação conjugal ou marital entre duas pessoas do mesmo sexo, que pode incluir crianças adotadas ou filhos biológicos de um ou ambos os parceiros.

Segundo o IBGE (BRASIL, 2000), família é definida por um conjunto de pessoas ligadas por laços de parentesco, dependência doméstica ou normas de convivência, todos residentes na mesma casa.

Quanto aos tipos de relações pessoais que se apresentam numa família, Lévi-Strauss (1976) refere três tipos de relação. São elas: a de aliança, casal; a de filiação, pais e filhos; e a de consanguinidade, irmãos. É nesta relação de parentesco, de pessoas que se vinculam pelo casamento ou por uniões sexuais, que se geram os filhos.

Em todas as famílias, independentemente da sociedade, cada membro ocupa determinada posição ou tem determinado estatuto, como, por exemplo, marido, mulher, filho ou irmão, sendo orientados por papéis. Papéis estes que não são mais do que "as expectativas de comportamento, de obrigações e de direitos que estão associados a uma dada posição na família ou no grupo social" (STANHOPE, 1999, p. 502).

Assim sendo, e começando pelos adultos na família, os seus papéis variam muito (STANHOPE, 1999), considerando como característicos os seguintes: a socialização da criança, relacionada com as atividades contribuintes para o desenvolvimento das capacidades mentais e sociais da criança; os cuidados às crianças, tanto físicos como emocionais, almejando seu desenvolvimento saudável; o papel de suporte familiar, que inclui a produção e/ou obtenção de bens e serviços necessários à família; o papel de encarregados dos assuntos domésticos, em que estão incluídos os serviços domésticos, que visam ao prazer e conforto dos membros da família; o papel de manutenção das relações 
familiares, relacionado com a manutenção do contato com parentes e implicando a ajuda em situações de crise; os papéis sexuais, relacionado com as relações sexuais entre ambos os parceiros; o papel terapêutico, que implica a ajuda e apoio emocional aos problemas familiares; o papel recreativo, relacionado ao lazer da família, visando o relaxamento e desenvolvimento pessoal.

Relativamente aos papéis dos irmãos, estes são promotores e receptores, simultaneamente, do processo de socialização na família, ajudando a estabelecer e manter as normas, promovendo o desenvolvimento da cultura familiar. Contribuem para a formação da identidade uns dos outros servindo de defensores e protetores, interpretando o mundo exterior, ensinando os outros sobre equidade, formando alianças, discutindo, negociando e ajustando mutuamente os comportamentos uns dos outros (STANHOPE, 1999).

Como os papéis, as funções estão igualmente implícitas nas famílias, como já foi referido. As famílias como agregações sociais, ao longo dos tempos, assumem ou renunciam funções de proteção e socialização dos seus membros, como resposta às necessidades da sociedade pertencente.

Nesta perspectiva, as funções da família regem-se por dois objetivos, sendo um de nível interno, como a proteção psicossocial dos membros, e o outro de nível externo, como a acomodação a uma cultura e sua transmissão. A família deve, então, responder às mudanças externas e internas de modo a atender às novas circunstâncias sem, no entanto, perder a continuidade, proporcionando sempre um esquema de referência para os seus membros ( MINUCHIN, 1990). Existe consequentemente uma dupla responsabilidade, isto é, a de dar resposta às necessidades quer dos seus membros, quer da sociedade (STANHOPE, 1999).

Identificamos como funções familiares as seguintes: geradora de afeto, entre os membros da família; proporcionadora de segurança e aceitação pessoal, promovendo um desenvolvimento pessoal natural; proporcionadora de satisfação e sentimento de utilidade, através das 
atividades que satisfazem os membros da família; asseguradora da continuidade das relações, proporcionando relações duradouras entre os familiares; proporcionadora de estabilidade e socialização, assegurando a continuidade da cultura da sociedade correspondente; impositora da autoridade e do sentimento do que é correto, relacionado com a aprendizagem das regras e normas, direitos e obrigações características das sociedades humanas. Para além destas funções, Stanhope (1999) acrescenta ainda uma função relativa à saúde, na medida em que a família protege a saúde dos seus membros, dando apoio e resposta às necessidades básicas em situações de doença.

A família, como uma unidade, desenvolve um sistema de valores, crenças e atitudes face à saúde e doença que são expressas e demonstradas através dos comportamentos de saúde-doença dos seus membros - estado de saúde da família (STANHOPE, 1999).

Acreditamos que a família tem como função primordial a de proteção, tendo, sobretudo, potencialidades para dar apoio emocional para a resolução de problemas e conflitos, podendo formar uma barreira defensiva contra agressões externas. Reforçamos ainda que a família ajuda a manter a saúde física e mental do indivíduo, por constituir o maior recurso natural para lidar com situações potenciadoras de estresse associadas à vida na comunidade.

Em relação à criança, sua necessidade mais básica remete-se à figura materna, que a alimenta, protege e ensina, assim como cria um apego individual seguro, contribuindo para um bom desenvolvimento da família e consequentemente para um bom desenvolvimento da criança. A família é então, para a criança, um grupo significativo de pessoas, de apoio, como os pais, os pais adotivos, os tutores, os irmãos, entre outros. Assim, a criança assume um lugar relevante na unidade familiar, onde se sente segura. A nível do processo de socialização a família assume, igualmente, um papel muito importante, já que é ela que modela e programa o comportamento e o sentido de identidade da criança. Ao crescerem juntas, família e criança promovem a acomodação da família às 
necessidades da criança, delimitando áreas de autonomia, que a criança experiencia como separação.

A família tem, também, um papel essencial para com a criança, que é o da afetividade, tal como já foi referido. Sua importância é primordial, pois consideramos o elemento afetivo tão imprescindível como os nutrientes orgânicos. Acreditamos que, sem o afeto de um adulto, o ser humano enquanto criança não desenvolve a sua capacidade de confiar e de se relacionar com o outro.

Desse modo, a família constitui o primeiro e o mais importante grupo social de uma pessoa, bem como o seu quadro de referência, estabelecido através das relações e identificações que a criança criou durante o desenvolvimento, tornando-a a matriz da identidade.

Importante colocar que ações para garantir efetivamente o direito de crianças e adolescentes ao convívio com a família e a comunidade estão definidas na política nacional, a ser seguida pela união, estados e municípios. Isso se deve ao plano aprovado em 13 de dezembro de 2006 pelo Conselho Nacional dos Direitos da Criança e do Adolescente (Conanda) e de Assistência Social (CNAS).

Contudo, a história social das crianças, dos adolescentes e das famílias revela que estas encontraram e ainda encontram inúmeras dificuldades para proteger e educar seus filhos.

Para Kliksberg (2003) a família latino-americana, em sua maioria, tem adotado um perfil de família desarticulado em aspectos importantes, instável, significativamente debilitada, que dificilmente pode cumprir as funções potenciais de unidade familiar.

Tais dificuldades foram traduzidas pelo Estado em um discurso sobre uma pretensa "incapacidade" da família de orientar os seus filhos. Ao longo de muitas décadas, este foi o argumento ideológico que possibilitou ao poder público o desenvolvimento de políticas paternalistas voltadas para o controle e a contenção social, principalmente para a população mais pobre, com total descaso pela preservação de seus vínculos familiares. Essa desqualificação das famílias em situação de 
pobreza, tratadas como incapazes, deu sustentação ideológica à prática recorrente da suspensão provisória do poder familiar ou da destituição dos pais e de seus deveres em relação aos filhos (BRASIL, 2006b).

Crianças e adolescentes têm o direito a uma família, cujos vínculos devem ser protegidos pela sociedade e pelo Estado. Nas situações de risco e enfraquecimento desses vínculos familiares, as estratégias de atendimento deverão esgotar as possibilidades de preservação dos mesmos, aliando o apoio socioeconômico à elaboração de novas formas de interação e referências afetivas no grupo familiar.

Durante o estabelecimento do vínculo afetivo na família, a criança tem como primeira referência a mãe. Pouco a pouco a criança vai assumindo e interiorizando, mediante a linguagem, determinados papéis e modelos relacionais. Consequentemente, ela é capaz de se posicionar criticamente, modificá-los, tornando-os seus. Isto pode significar a constituição de sua autonomia e a construção de um projeto que organize e norteie sua vida (FENELON, 2004).

Entretanto, de acordo com estudos, dificuldades interpessoais quando presentes comprometem a qualidade do relacionamento, além de oferecer modelos inadequados de desempenhos sociais para os filhos, sendo a exposição da criança a práticas parentais pouco construtivas ou a privação de envolvimento afetivo (PACHECO et al., 2005).

A proximidade da mãe com o filho por longo período parece favorecer a ocorrência de situações de dificuldades interpessoais. Estudos como o de Brito et al. (2005) identificaram que a mãe é a que mais agride os filhos no ambiente doméstico.

A ausência de afeto no relacionamento familiar durante a infância torna o desenvolvimento da identidade materna uma "auto" dificuldade, limitando a possibilidade de experiências positivas de contato físico, cuidado e socialização. Pouca estrutura psicológica para assumir a responsabilidade materna representa a origem dos conflitos, levando a uma falha no sentimento do papel materno (BRUNDENELL, 1997). 
A falta de habilidades sociais e os traços antissociais dos pais são considerados importantes fatores de risco familiar. Os traços antissociais maternos são os principais contribuintes para o desenvolvimento de interações coercitivas, as quais, em ambientes familiares, excluem e dificultam a utilização de técnicas positivas de motivação e guia na educação dos filhos (PATTERSOM; BANK, 1989).

As respostas não apropriadas das mães ante as condutas do filho e o modelo que reflete comportamentos inadequados têm implicações no desenvolvimento e manutenção de condutas agressivas nos filhos. Entre essas respostas não apropriadas incluem-se as atitudes desproporcionalmente hostis, teatrais, histéricas, aquelas que mobilizam fortemente as emoções (chantagens emocionais), o completo descaso, dentre outras.

Em vários estudos aparece uma correlação entre a agressividade infantil e a tendência das mães a realizar atribuições hostis à conduta desses filhos (DIX; LOCHMAM, 1990). Com frequência as mães de crianças agressivas tendem a atribuir mais hostilidade às condutas de seus filhos, qualificando negativamente traços de suas personalidades e ressaltando sempre a má conduta da criança. Não é raro que a mãe constantemente estabeleça comparações desvantajosas e depreciativas entre as condutas agressivas dessas crianças problemáticas com outras crianças e, às vezes, com seus próprios irmãos.

Tem-se relacionado também a hostilidade materna como a sintomatologia depressiva da mãe e condutas agressivas em escolares. A depressão materna prediz problemas comportamentais em pré-escolares e multiplica por seis o risco de transtorno de conduta agressiva na criança. Estes sintomas depressivos da mãe podem estar presentes nas primeiras etapas da vida da criança e condicionar o estabelecimento de um vínculo inseguro ou desorganizado (J ANÉ et al., 1999).

Outro fator de risco familiar é o consumo de drogas, lícitas ou ilícitas, por um de seus membros. Vários trabalhos associam o alto consumo do álcool à desagregação familiar (HIJ AR-MEDINA et al., 2003; 
VALDEZ-ROJ AS et al., 2002). A incidência de violência intrafamiliar tem sido considerada maior em abusadores de substâncias psicoativas na maioria das sociedades e culturas, estando presente nos diferentes grupos econômicos (DAY et al., 2003).

Chalub e Telles (2006) confirmam que os transtornos por uso de substâncias psicoativas exercem considerável impacto sobre os indivíduos, suas famílias e a comunidade, determinando prejuízo à saúde física e mental, comprometimento das relações, perdas econômicas e, algumas vezes, chegando a problemas legais. Percebemos que vários estudos assinalam a associação entre transtorno do uso de substâncias psicoativas e a violência intrafamiliar.

Observa-se que a maior parte das pesquisas aponta a presença de associação entre esses transtornos e o uso de substâncias e criminalidade. É alta a proporção de atos violentos quando álcool ou drogas estão presentes entre agressores e suas vítimas, ou em ambos (CHALUB; TELLES, 2006).

Tendo por base o quadro teórico acima apresentado é que buscaremos analisar o comportamento agressivo de mães para com seus filhos, considerando a trajetória de vida destas mulheres em seu contexto sociocultural familiar e a conjunção com a dependência do álcool e das drogas.

\subsection{O consumo de álcool e drogas na família como fator de risco para violência}

O uso de drogas faz parte do contexto e da história da sociedade, utilizado em rituais, em situações de festas, de lazer, contrapondo-se ou participando de outros aspectos da vida das sociedades (ADORNO, 2008). 
A idéia de fazer do álcool um aliado do prazer lícito data da Antiguidade, mais especificamente visível no Império Romano. Havia, nessa época, uma tendência aos prazeres e excessos, como por exemplo, o uso abundante do vinho - ideologia báquica - representado pela figura do deus Baco da mitologia grega, deus do prazer e da sociabilidade. Numa sociedade em que o prazer não era menos legítimo do que a virtude, representada por Hércules, o vinho ocupava um lugar privilegiado, ainda que já se soubesse de seus efeitos negativos (ÁRIES; DUBY, 1990).

No caso das sociedades ocidentais, a própria presença do vinho como elemento de celebração da religião católica traz esse elemento de extenso significado e uso na história social (ADORNO, 2008).

Atualmente, o álcool, cientificamente conhecido como etanol (álcool etílico), é a droga mais consumida em todo o mundo. Considerando-se o uso pelo menos uma vez na vida, o álcool é a droga mais consumida em todas as faixas etárias, começando entre os dez e os doze anos. Estudo realizado por Galduróz, Noto e Carlini (1997), por intermédio do Centro Brasileiro de Informações sobre Drogas Psicotrópicas (CEBRID), com estudantes de escolas de ensino fundamental e médio, de dez capitais brasileiras, revelou que o álcool e os solventes são as drogas mais consumidas por adolescentes. A pesquisa revela, ainda, que $65 \%$ dos alunos pesquisados já consumiram essa droga pelo menos uma vez na vida. A cerveja foi a bebida mais apontada pelos adolescentes, sendo que $70 \%$ destes relataram seu uso, seguido pelo vinho $(27 \%)$ e pelos destilados (3\%).

Esse consumo aumentou drasticamente com a produção de bebidas alcoólicas em escala industrial e, particularmente, após sua inserção na sociedade de consumo como mais uma mercadoria a ser vendida à população. A associação entre a produção em massa e a divulgação, via campanhas publicitárias, fez com que a produção brasileira de cerveja, a bebida alcoólica mais consumida entre os jovens, alcançasse a expressiva marca de 9 bilhões de litros anuais, no ano de 2005 (SIQUEIRA, 2005). 
A respeito do consumo de álcool observa Adorno (2008, p.7) que

a sociedade contemporânea traz à tona situações complexas que envolvem uso e consumo como expressão de uma lógica capitalista hegemônica que se dá pelo consumo acelerado e por excesso, como no ritmo exigido pelo trabalho dentro desse sistema. Se a produção industrial e o modelo fabril impunham um ordenamento social dividindo consumo/lazer, produção/consumo, a ponto de tornar o uso de álcool como elemento recreativo e presente no momento de término ou de folga do trabalho, o uso de drogas associados quer ao lazer, quer às ações de ocupação profissional tornou-se variado e complexo na sociedade contemporânea, podendo-se inferir ritmos específicos e usos associados a diferentes estilos, ações e significados.

Nesta direção, acredita-se que a entrada e a permanência no mundo das drogas, lícitas ou ilícitas, não é uma questão que se dá ao acaso. Pensa-se, igualmente, que seja produzida de alguma maneira, diariamente, talvez pela ordem social vigente e hegemônica (que adota uma visão simplista do consumidor), pelos modelos sociais da sociedade capitalista, pela construção da moralidade prejudicada por essa sociedade consumista e individualista ou uma mistura desses fatores.

Existem fatores que são postos como fator de risco para o consumo de substâncias psicoativas. Para Toscano Junior (2001), no âmbito da cultura e sociedade, as leis e normas sociais favoráveis, a disponibilidade das drogas e privações econômicas extremas. No âmbito individual inclui a baixa estima, falta de autocontrole e assertividades, comportamento antissocial precoce, doença pré-existentes (transtorno de déficit de atenção e hiperatividade), baixa religiosidade e vulnerabilidade psicossocial. No domínio familiar, o uso do álcool ou outras drogas pelos pais e familiares, isolamento social entre os membros da família, padrão familiar disfuncional, falta do elemento paterno.

A instituição familiar é considerada um dos elos mais fortes de uma cadeia multifacetada que pode levar ao uso abusivo de álcool e drogas, além de atuar também como importante fator de proteção. Isto se explica pelo fato de que os diferentes comportamentos sociais, entre eles o consumo de substâncias psicoativas, são aprendidos, predominantemente, a partir das interações estabelecidas entre o jovem e 
suas fontes primárias de socialização que, no ocidente, são a família, a escola e o grupo de amigos.

O resultado dessa constante interação é o estabelecimento de um vínculo que possibilita a comunicação de um conjunto de normas. Dificuldades percebidas nestas interações sociais podem se configurar em sérios fatores de risco para o surgimento de problemas na vida dos indivíduos (SCHENKER; MINAYO, 2003).

A falta de suporte parental, o uso de drogas pelos próprios pais, atitudes permissivas dos pais perante o consumo e incapacidade dos pais de controlar os filhos são fatores predisponentes à iniciação ou continuação de uso de drogas (BAHR; HOFMANN; YANG, 2005).

O consumo de drogas ilícitas, como a maconha e a cocaína, é relativamente baixo quando comparado ao uso das drogas lícitas, como o álcool e o tabaco (GALDURÓZ; NOTO; CARLINI, 1997). Ao contrário das drogas ilícitas, o primeiro contato que a maioria dos adolescentes tem com o álcool ocorre dentro de casa, sob o olhar complacente da família, que aceita e tolera esse tipo de substância.

Essa postura familiar sinaliza a idéia de que o álcool, quando devidamente utilizado em situações sociais, tem boas funções, como promover encontros sociais ou o "relaxamento" após um dia estafante. O problema é que esse uso nem sempre é devido e o exemplo exibido não é o da taça de champanha para brindar o ano novo, ou o de um copo de chope, no final de semana, mas de doses diárias para "esquecer dos problemas" ou ficar "um pouco mais alegre".

Segundo Adorno (2008), o hábito do excesso é uma característica da sociedade de consumo na contemporaneidade; no caso do consumo do álcool pode desencadear situações desestruturantes no cotidiano e nas relações sociais, ou pode adequar-se a outros comportamentos esperados no desempenho profissional ou nos círculos de relacionamento.

A Organização Mundial de Saúde (WHO, 2004b) considera que o uso nocivo do álcool encontra-se entre as principais causas de enfermidades, lesões, violência doméstica - sobretudo contra mulheres e 
crianças, além de outros problemas sociais, mortes prematuras, repercutindo de forma grave no convívio humano, afetando pessoas, famílias e comunidades e a sociedade em seu conjunto, tendo forte relação com as desigualdades sociais e sanitárias.

Dentro da realidade brasileira, tal gravidade vem tomando grandes proporções, não se limitando ao sofrimento e consequências individuais ou somente no âmbito familiar, mas podendo ser percebida por agravos sociais que decorrem do alcoolismo ou que o reforçam, presentes nos mais diversos segmentos da sociedade.

Segundo o Ministério da Saúde, os agravos decorrentes do uso do álcool são extremamente dispendiosos, afetando a vida dos indivíduos em diversos âmbitos. Suas consequências podem ser constatadas em uma grande porcentagem de mortes não naturais/acidentais, anos de incapacidade, doenças e outras complicações indiretas aos danos acometidos pelo uso abusivo do álcool ao longo de anos (BRASIL, 2003) .

$O$ uso de substâncias psicoativas tem sido associado principalmente à ocorrência de violência. Entretanto, observa Adorno (2008) que é preciso cuidado em se estabelecer relações entre questões de natureza complexa, como o consumo de álcool e violência.

O autor acima problematiza a relação entre esses dois temas complexos, partindo da análise de dados empíricos obtidos de pesquisas. Em uma dessas pesquisas refere que, de uma amostra de 2372 domicílios encontrados em 27 municípios com mais de 200.000 habitantes localizados no Estado de São Paulo, detectou-se situações de violência em $31,6 \%$ dos domicílios, e nesses $52,7 \%$ encontrava-se o relato do uso de álcool e em $9,7 \%$ de outras drogas. Em relação aos que ingeriram álcool cerca de $91 \%$ eram homens, e $83,3 \%$ em relação a outras drogas. A faixa de idade dos que fizeram uso de álcool era superior aos que referiram o uso de outras drogas. O estudo conclui que embora tenha se tornado do senso comum a relação entre uso de drogas e violência, esta ocorreu em uma quantidade menor de domicílios, relacionou-se com o uso de álcool e com consumidores do sexo masculino, destaca também que o reverso 
pode ser concluído, nem todas as pessoas que fazem uso do álcool se envolvem em violência.

Fato a considerar nos dados apresentados do estudo acima referido é o percentual majoritário de homens que ingerem álcool e outras drogas, o que nos levou a buscar na literatura como se apresenta o consumo entre as mulheres, visto que nosso cenário de estudo são mães agressoras dos filhos que convivem com o consumo abusivo pessoal e familiar de álcool em seu contexto relacional.

Encontramos grande dificuldade, pela escassez de estudos sobre alcoolismo feminino e suas especificidades, não só em estudos biomédicos, mas também na área das ciências sociais. Além disso, dentre os estudos levantados, muitos se referem às dificuldades não apenas no tratamento de tais especificidades, como no próprio diagnóstico do alcoolismo em mulheres. Esta dificuldade em diagnosticar o alcoolismo na população feminina já nos levanta alguns questionamentos quanto à invisibilidade da mulher alcoolista, seja na forma como é tratada, na própria forma como adoece, nas dificuldades na procura por ajuda em serviços de saúde, ou ainda, nas lacunas no diagnóstico destes serviços sobre o alcoolismo feminino.

Em estudos sobre dependência de álcool no período entre 1970 e 1984 verificou que apenas $8 \%$ dos participantes eram mulheres. Apenas 25 estudos sobre dependência apoiou as diferenças entre sexos no período entre 1984 e 1989 (HOCHGRAF; BRASILIANO, 2004).

Embora considerando que não há uma relação linear entre consumir álcool e envolver-se com situações de violência, é possível identificar na literatura estudos que buscam analisar a relação entre o beber feminino e a violência de gênero sofrida:

Observamos que o beber feminino está atravessado por essas relações e interações sociais onde as relações de gênero estão muito presentes. Particularmente, observamos uma questão grave que é a relação do beber feminino com a violência. Não da perspectiva (não menos significativa) onde o alcoolismo provoca a violência, mas sim, onde a violência pode contribuir para gerar alcoolismo (CÉSAR, 2005). 
A leitura de César (2005) considera as experiências de violência de gênero em diversas situações, às quais as mulheres foram submetidas como fatores envolvidos na dinâmica de sofrimento e evolução do alcoolismo. Em sua análise, César sugere a violência como um fator que contribui para gerar o alcoolismo, ou seja, o alcoolismo poderia ser interpretado como um efeito possível de tal violência, não desconsiderando outros fatores associados neste processo de adoecimento, mas também não ignorando a relevância destas experiências na história destas mulheres, atravessada pelas construções e violências de gênero.

A autora aponta o sofrimento e violência vividos por mulheres alcoolistas e a relação possível destas vivências com a abstinência e o abuso da bebida, sinalizando a presença de contradições entre estereótipos de gênero e a história e condições de vida das mulheres entrevistadas em sua pesquisa. César faz referência ainda a sentimentos como insatisfação e frustração associadas a não adequação dessas mulheres tanto às expectativas tradicionais, quanto às ideologias novas sobre o ser mulher; o que pode favorecer uma sensação de tristeza e desamparo pelo não pertencimento e não cumprimento de papéis femininos. A autora discute a presença dos estereótipos de gênero nos conflitos vividos por estas mulheres, apontando uma relação dialética entre o alcoolismo e estas experiências, onde a dinâmica do 'beber' atravessa a construção do 'ser mulher':

\footnotetext{
Ser mulher, como se vêem enquanto mulher e mulher alcoolista são face da mesma moeda. Refletem toda a ambiguidade da sexualidade feminina e mais, a ambiguidade do beber feminino. $E$ a ambiguidade do beber reflete as relações de gênero, os estereótipos, portanto, a marca social do gênero feminino no alcoolismo em mulheres. (CÉSAR, 2005, p.104)
}

Considerações sobre o alcoolismo e o uso de drogas por mulheres e os reflexos no ato de ser mãe as colocam frequentemente como rotuladas de negligentes, sendo ainda ligadas aos estereótipos de mulheres que são mais agressivas, tendendo à promiscuidade e que falharam ao tentar desempenhar o papel doméstico (HOCHGRAF; BRASILIANO, 2004; KEARNEY; MURPHY; ROSENBAUM, 1994). 


\section{Pressupostos}

Os significados que as mulheres/mães atribuem à maternidade e as formas de atuarem no cuidado com os filhos guardam relação com processos de socialização nos quais foram submetidas junto às suas mães e famílias, revelando possivelmente uma cíclica violência familiar que, na maioria das vezes, se mostra naturalizada.

A dissociação do papel materno que se expressa em violência contra a criança está ligada a vários fatores isolados ou em conjunção; tais como sua condição social e relacional além do consumo de álcool e drogas ilícitas. 


\section{Trajetória Metodológica}

\subsection{Tipo de estudo}

Para a compreensão do objeto de estudo, optamos pela abordagem qualitativa, a qual possibilita apreender a complexidade do fenômeno a ser estudado, trazendo para a análise o subjetivo e o objetivo dos sujeitos sociais, de acordo com suas visões de mundo. O pesquisador que usa essa abordagem acredita que seres humanos únicos atribuem significados a suas experiências e que elas derivam do contexto de vida (WOOD; HABER, 2001).

A Pesquisa Qualitativa parece ter vocação para mergulhar na profundidade dos fenômenos. Faz isto de forma compreensiva, abrindo-se para apreender a toda a informação subjacente ao fenômeno, leva em conta toda a sua complexidade e particularidade. Não almeja alcançar a generalização, mas sim o entendimento das singularidades (BIGNARDI, 2003).

\subsection{Contexto do Estudo}

O campo de estudo é concebido como um recorte que o pesquisador faz, em termos de espaço, em uma realidade social, que vai representar a realidade empírica a ser estudada.

Assim, o universo empírico a ser considerado será de mulheres que participam de um Projeto denominado "Intervenções Breves para pessoas que abusam de álcool e drogas", instituído em Jardinópolis/SP, junto à Fundação PROMAR (Projeto Marcenaria da Música de Jardinópolis/SP). 
O projeto foi criado após constatação, por Roque (2001, 2006), que os casos de violência intrafamiliar que chegam ao Poder Judiciário na Comarca de Jardinópolis, mesmo pós-intervenção judicial, continuam reincidentes, sendo que o município não dispõe de um núcleo de atenção aos usuários de álcool e drogas.

Estas "Intervenções Breves" possuem como objetivos:

- Recuperar os alcoolistas e/ou dependentes químicos reintegrando-os a suas famílias e à sociedade;

- Promover a transformação e o crescimento pessoal, através da mudança de estilo de vida, levando-os a vencer suas próprias limitações.

A equipe de atendimento é multidisciplinar, constituindo-se de assistentes sociais, enfermeiros, psicólogos, médicos, advogados e alunos de graduação dessas profissões, atuando sob supervisão acadêmica. É coordenada por duas assistentes sociais do Fórum de Jardinópolis.

As reuniões do grupo são realizadas aos sábados pela manhã e o grupo é dividido em adultos e crianças e, nas reuniões dos adultos, são abordados temas educativos diversos, como: Sexualidade e prevenção de doenças sexualmente transmissíveis; Uso de álcool e drogas; Cuidados com a saúde; Violência intrafamiliar; Cuidados com o meio ambiente, Legislação, Cidadania, dentre outros.

Possui como público alvo pessoas adultas, crianças e adolescentes, de ambos os sexos, e suas famílias com uso abusivo de álcool e drogas, residentes no município de Jardinópolis/SP e que desejam participar do grupo.

Jardinópolis está localizada no Estado de São Paulo, é constituído por uma população de 50.000 habitantes, em uma área de $552 \mathrm{~km}$ Limitase com Ribeirão Preto, Brodowski, Sertãozinho, Batatais e Sales de Oliveira.

As principais atividades econômicas da cidade são agricultura e pecuária, destacando-se na primeira a cana-de-açúcar, milho, algodão, 
manga e abacate e, na segunda, criação de bovinos. A população é de baixa renda, sendo que a maioria trabalha na área rural, vivendo, aproximadamente, com um salário mínimo mensal.

\subsection{Sujeitos do Estudo}

Como observa Minayo (2006), em pesquisa social de abordagem qualitativa, a composição da amostra não passa pela representatividade numérica e sim pela representatividade da complexidade do objeto em estudo.

Assim, o recorte empírico do estudo foi dado por saturação, sendo composto por dez mulheres, mães, maiores de 18 anos, as quais vivem em um contexto de álcool, drogas e violência, integrantes do Grupo de apoio supracitado, em Jardinópolis/SP. Foram entrevistadas dez mulheres aleatoriamente de acordo com a assiduidade às reuniões. Houve sucessivas inclusões de sujeitos até que se pôde estabelecer uma análise adequada do problema.

Fontanella, Ricas e Turato (2008) referem que a amostragem por saturação é uma ferramenta conceitual frequentemente empregada nos relatórios de investigações qualitativas em diferentes áreas no campo da saúde. É usada para estabelecer ou fechar o tamanho final de uma amostra em estudo, interrompendo a captação de novos componentes. 0 fechamento amostral por saturação teórica é operacionalmente definido como a suspensão de inclusão de novos participantes quando os dados obtidos passam a apresentar, na avaliação do pesquisador, certa redundância ou repetição, não sendo considerado relevante persistir na coleta de dados. 


\subsection{Coleta de dados}

Acredita-se que, para melhor compreensão da realidade dos participantes envolvidos na investigação, faz-se necessário o estabelecimento de técnicas que visem ao levantamento de dados, possibilitando ao pesquisador uma melhor interação com os mesmos, no sentido de ampliar o entendimento do fenômeno em suas variadas dimensões.

Dentre as técnicas para coleta de dados, utilizou-se a História de Vida, que busca a visão da pessoa acerca das suas experiências subjetivas de certas situações. Essas situações estão inseridas em um período de tempo de interesse ou referem-se a algum evento ou série de eventos que possam ter tido algum efeito sobre o respondente (MOREIRA, 2002). Neste estudo, estão relacionadas ao processo de socialização das mulheres entrevistadas e ao seu relacionamento mãe-filho.

A técnica História de Vida consiste na oportunidade dos sujeitos em relatar sua vida, tal e qual sua visão de mundo e de sua realidade. Constitui uma narrativa utilizada pelo sujeito para exprimir os conteúdos de uma parte de sua experiência vivida (BERTAUX, 1980).

Apesar de valorizar o conhecimento das vivências e experiências de cada indivíduo em particular, o Método de História de Vida permite projetarmos esta realidade singular para uma realidade também possível ao grupo social no qual este indivíduo está inserido. “Toda entrevista individual traz à luz direta ou indiretamente uma quantidade de valores, definições e atitudes do grupo ao qual o indivíduo pertence" (GLAT, 1989, p.31).

A História de Vida pode ser dividida em três grandes tipos: abrangente, tópica ou editada. Optamos pela História de Vida Tópica, porque oferece um quadro mais segmentado da vida do sujeito (MOREIRA, 2002). 
Por ser uma entrevista aberta, a História de Vida não contempla um roteiro previamente estabelecido, porém utilizamos a entrevista procurando ressaltar alguns aspectos que servirão como norteadores.

Dessa forma, no sentido de atingirmos os objetivos referentes à compreensão da violência perpetrada por mães junto aos seus filhos, tendo por base seu contexto histórico e social, o instrumento de coleta de dados seguiu um roteiro norteador (APÊNDICE A).

Nesse roteiro, construído pela pesquisadora, abordamos cinco etapas para nortear a entrevista de uma forma dinâmica e aberta, não estática. Primeiramente foi abordado com a mulher entrevistada dados para sua identificação própria, como idade, renda, ocupação, número de filhos, escolaridade, número de membros da família que moram juntos e desempregados. Após essa abordagem inicial, conversamos sobre sua família de origem, um assunto tratado pelas mulheres com desembaraço; às vezes, com saudades, tristeza e até comoção. Em seguida, abordamos o tema relacionamentos, em que a mulher colocava, sobre seus parceiros anteriores e atual, pontos positivos e pontos negativos. Depois, a abordagem era sobre seu relacionamento com seus filhos, suas concepções sobre educação, maternidade, atitudes perante erros e acertos dos filhos e se os filhos foram planejados. Por fim, se ainda não havia sido contemplado o tema violência, finalizávamos a entrevista abordando esse assunto delicado, em um momento no qual tínhamos mais cumplicidade e em que ambas as partes já se sentiam mais à vontade. É relevante colocar que as mulheres verbalizavam quanto gostavam de falar sobre suas vidas e quanto aquela conversa havia sido importante.

Também utilizamos a observação participante do ambiente relacional (interação mãe-filho), a qual foi bastante importante para a análise dos dados. Este é o tipo de observação que implica dados mais reativos, porque o pesquisador está menos distante dos seus sujeitos. Ele interage plenamente com os sujeitos sem que haja distinção entre sujeitopesquisador. Durante as atividades propostas no projeto, e mesmo no 
momento da alimentação, era possível analisar e colher dados sobre a relação das mães com seus filhos.

As entrevistas ocorreram aos sábados pela manhã, em ambiente reservado da I greja da Lapa de Jardinópolis, espaço em que aconteciam as reuniões do projeto "Intervenções Breves para pessoas que abusam de álcool e drogas". A mulher que seria entrevistada era comunicada com uma semana de antecedência para que ficasse ciente de que, no sábado seguinte, não participaria da reunião do projeto, mas sim da entrevista da pesquisa. Se ela concordasse, era a próxima a ser entrevistada.

Esse tipo de entrevista com mulheres envolvidas em episódios de violência nos permite explorar dados relativos à reprodução do ciclo da violência no seu contexto social, compreendendo sua história de vida e observando relações com processos de socialização nos quais foram submetidas junto a suas mães e suas famílias.

Com o objetivo de garantir o anonimato dos relatos, identificamos os sujeitos por letras, S1, S2, S3... S10, na apresentação dos resultados.

As entrevistas foram gravadas, com o consentimento das informantes e as observações registradas em um diário de campo, sendo aplicadas pela própria pesquisadora.

\subsection{Análise dos dados}

A análise de conteúdo tem sido muito utilizada na análise de comunicações nas ciências humanas e sociais. Minayo (2006) afirma ser o método mais comumente adotado no tratamento de dados de pesquisas qualitativas.

Para Bardin (1979), a análise de conteúdo abrange as iniciativas de explicitação, sistematização e expressão do conteúdo de mensagens, com a finalidade de se efetuarem deduções lógicas e justificadas a 
respeito da origem dessas mensagens (quem as emitiu, em que contexto e/ou quais efeitos se pretende causar por meio delas). Mais especificamente, a análise de conteúdo constitui:

\begin{abstract}
Um conjunto de técnicas de análise de comunicação visando a obter, por procedimentos sistemáticos e objetivos de descrição do conteúdo das mensagens, indicadores (quantitativos ou não) que permitam a inferência de conhecimentos relativos às condições de produção/recepção destas mensagens (BARDIN, 1979. p.42).
\end{abstract}

Como se pode perceber pela definição apresentada, a autora defende que a análise de conteúdo oscila entre os dois polos que envolvem a investigação científica: o rigor da objetividade e a fecundidade da subjetividade, resultando na elaboração de indicadores quantitativos e/ou qualitativos que devem levar o pesquisador a uma segunda leitura da comunicação, baseado na dedução, na inferência. Essa nova compreensão do material textual, que vem substituir a leitura dita "normal" por parte do leigo, visa a revelar o que está escondido, latente, ou subentendido na mensagem.

Utilizamos, para o tratamento dos dados, a técnica de análise de conteúdo, modalidade temática. O motivo da escolha de tal técnica se justifica por ser um instrumento de análise que, com maior rigor, analisa o vasto campo das comunicações, facilitando a tentativa exploratória e enriquecendo as interpretações.

Minayo (2006) descreve as etapas que compreendem a análise de conteúdo modalidade temática:

a) A pré-análise: fase de organização e sistematização das idéias, em que ocorre a escolha dos documentos a serem analisados, a retomada das hipóteses e dos objetivos iniciais da pesquisa em relação ao material coletado, e a elaboração de indicadores que orientarão a interpretação final. A pré-análise pode ser decomposta em quatro etapas: leitura flutuante, na qual deve haver um contato exaustivo com o material de análise; constituição do Corpus, que envolve a organização do material de forma a responder a critérios de exaustividade, representatividade, homogeneidade e pertinência; 
formulação de hipóteses e objetivos, ou de pressupostos iniciais flexíveis que permitam a emergência de hipóteses a partir de procedimentos exploratórios; referenciação dos índices e elaboração dos indicadores a serem adotados na análise, e preparação do material ou, se for o caso, edição;

b) A exploração do material: trata-se da fase em que os dados brutos do material são codificados para se alcançar o núcleo de compreensão do texto. A codificação envolve procedimentos de recorte, contagem, classificação, desconto ou enumeração em função de regras previamente formuladas, e;

c) Tratamento dos resultados obtidos e interpretação: nessa fase, os dados brutos são submetidos a operações estatísticas, a fim de se tornarem significativos e válidos e de evidenciarem as informações obtidas. De posse dessas informações, o investigador propõe suas inferências e realiza suas interpretações de acordo com o quadro teórico e os objetivos propostos, ou identifica novas dimensões teóricas sugeridas pela leitura do material. Os resultados obtidos, aliados ao confronto sistemático com o material e às inferências alcançadas, podem servir a outras análises baseadas em novas dimensões teóricas ou em técnicas diferentes.

As informações inicialmente colhidas, uma vez trabalhadas, revelam a sua especificidade de concepção sobre questões particulares e globais; e, mais do que isso, de expressão da visão social de mundo do seguimento em questão e sua visão enquanto ator participante do processo de educação e construção da personalidade e moral das crianças vítimas de violência intrafamiliar.

A análise qualitativa das entrevistas levou à ordenação e classificação dos dados, referenciados por temas, e refinados em expressões de síntese, as categorias empíricas, as quais foram trabalhadas. 
O produto final não é estático, é sempre provisório, não se esgota em si mesmo, sendo possível sua ampliação através de novos olhares. Neste sentido, esperamos colaborar tanto para a melhoria da práxis dos profissionais interessados pelo tema em questão, como para ampliar o saber nesta área de violência intrafamiliar contra a criança, a fim de que medidas mais objetivas sejam tomadas por órgãos responsáveis.

\subsection{Aspectos éticos da pesquisa}

A pesquisa foi realizada respeitando-se os aspectos éticos para desenvolvimento de pesquisas com seres humanos, atendendo à Resolução 196/96, iniciando-se a coleta de dados somente após a aprovação do Comitê de Ética em Pesquisa da Escola de Enfermagem de Ribeirão Preto da Universidade de São Paulo (EERP/USP).

Além disso, foi enviada, ao presidente da Fundação PROMAR, responsável pelo projeto "Intervenções Breves" de Jardinópolis, Sr. Lupercio Pedro Ficoto, uma solicitação de autorização para a realização da pesquisa, a qual foi consentida (APÊNDICE B).

Os atores da investigação concordaram em participar da pesquisa após serem esclarecidos sobre seus objetivos e garantido o anonimato e confidencialidade dos dados, além de estarem cientes e assinarem o Termo de Consentimento Livre e Esclarecido (APÊNDICE C).

Devido às possíveis formas das participantes de enfrentar o tema em questão, foram oferecidos a elas suporte psicológico e orientações quanto aos recursos que a comunidade dispõe, a depender da necessidade apresentada e/ou exposta, a fim de garantir seu bem-estar. Enfatiza-se que o próprio projeto "Intervenções Breves para pessoas que abusam de álcool e drogas" tem como uma de suas finalidades fornecer suporte nesse sentido. 


\section{Resultados e Discussão}

A partir dos dados coletados, por meio da técnica de História de vida tópica e da observação participante do ambiente relacional (interação mãe-filho), caracterizamos, primeiramente, as mulheres participantes para depois iniciar a análise das entrevistas.

\subsection{Perfil das mães que manifestam atos de violência contra seus filhos}

Constatamos que as dez mulheres entrevistadas no estudo apresentaram uma média de idade de 35 anos, variando de 22 a 47 anos. Observamos, assim, uma grande variabilidade na faixa etária das entrevistadas. Quanto à ocupação, $80 \%$ eram do lar, 10\% faziam serviços gerais e $10 \%$ estavam desempregadas. Percebe-se que a grande maioria dessas mulheres não possui atividade remunerada. Referem ser dependentes financeiramente de um familiar ou do parceiro.

Cerca de $70 \%$ das entrevistadas cursaram apenas ensino fundamental incompleto e $20 \%$ eram analfabetas, o que significa que $90 \%$ das mulheres possuíam baixa ou nenhuma escolaridade.

No que diz respeito ao estado civil, $50 \%$ eram casadas ou possuíam relação estável, $10 \%$ eram solteiras e $40 \%$ separadas. Nos relatos das mulheres, percebemos um grande número de famílias reconstituídas ou recompostas. Famílias reconstituídas são definidas como a constituição de novo convívio familiar, oriundo muitas vezes da dissolução de sociedade conjugal ou do término da união estável e da constituição de novo casamento ou de nova união estável. São relações que estabelecem a possibilidade de casais com filhos oriundos da nova relação ou relação com os filhos do outro. Segundo Segalen (1999, p.93), 
Família recomposta designa a situação pós-divórcio, quando o casal se encontra multiplicado por dois, dispondo então os filhos de dois lares de referência, aquele onde residem com o progenitor dito isolado e aquele onde reside o outro progenitor.

A renda familiar das entrevistadas variou de zero a $\mathrm{R} \$ 500,00$, sendo que $90 \%$ dos sujeitos referiram viver com menos de um salário mínimo. Isso posto, expõe-se o número de membros por família que moram juntos em uma mesma casa: média de 6 indivíduos, variando de 3 a 8 indivíduos. As famílias apresentam de 0 a 3 desempregados. Percebemos, portanto, que as entrevistadas encontram-se vivendo abaixo da linha da pobreza. Pelos critérios do Instituto de Pesquisa Econômica Aplicada (IPEA, 2007), órgão ligado à Secretaria de Assuntos Estratégicos da Presidência da República, encontra-se abaixo da linha da pobreza quem tem rendimento domiciliar per capita menor que meio salário mínimo.

Quando se analisou o número de filhos das mulheres, foi verificada uma média de cinco filhos vivos por mulher, havendo uma variação de 1 a 11 filhos. É relevante colocar que apenas uma mulher possuía um único filho, e relatou ter abortado 5 ou 6 vezes, sendo que estava grávida no momento da entrevista. Referiu que grande parte dos abortos aconteceram devido a espancamento pelo parceiro.

Além desses dados, traçamos um breve perfil das mães, sujeitos deste estudo, os quais estão descritos no Apêndice $D$.

\subsection{Significando a violência contextualizada na família anterior e atual de mães agressoras}

Após o processo de organização do material coletado nas entrevistas, das várias leituras desse material e de sua análise qualitativa, apreendemos das falas das mulheres dois momentos distintos de suas vidas: o seu passado na família de origem e o seu presente na família 
atual, que, embora separados pelo tempo, guardam articulações que, estando ou não conscientes para estas mulheres, deixam marcas indeléveis em suas vidas.

Assim, as categorias temáticas extraídas são as seguintes:

Trajetória de vida no contexto da família de origem

- Convivendo com as perdas: “... eu fiquei pro mundo";

- Convivendo com alcoolismo, pobreza e violência em família;

- Convivendo com afetos e desafetos: "eu achava tão bom, tão gostoso quando ela me chamava de filha, era muito raro, muito raro".

O contexto da família atual: repetindo trajetórias de vida

- "Eu tentei construir uma família... bem ou mal ela tá aí";

- "Minha vida da infância ao casamento parece que foi igual (...) continuei sendo agredida";

- "Eu bato nele sim (...), mas em vista do que eu fui tratada, eu trato ele muito bem".

Assim, a discussão que se segue procura interpretar o exposto pelos atores sociais entrevistados, à luz das categorias temáticas configuradas pelos núcleos de sentido presentes nas falas desses atores.

\subsubsection{Trajetória de vida no contexto da família de origem}

Nas distintas trajetórias de vida das mulheres entrevistadas em suas famílias de origem encontramos pontos em comum que retratam suas vivências quando criança, ou seja, convivendo com perdas, situações de alcoolismo e violência, afetos e desafetos, as quais estão expressas nas categorias temáticas descritas abaixo. 


\section{Convivendo com as perdas: “... eu fiquei pro mundo"}

No segundo momento da entrevista, em que abordamos inicialmente sobre a família de origem da mulher entrevistada, percebemos que muitas delas sofreram inúmeras perdas de familiares próximos, entes queridos, como a mãe ou o pai, acarretando desestruturação da família nuclear - aquela formada por pai, mãe e filhos do casal. Tal perda pode estar relacionada à morte desse familiar, ou mesmo a uma separação ocorrida por inúmeros motivos.

Morava com minha madrinha, meu pai morreu com 30 anos, minha mãe é viva e mora em Santa Rita do Passa Quatro. (...) eu vim pra cá porque minha mãe não tinha condição de criar nós quatro irmão, aí ela deu nóis pra minha madrinha. (S2)

Identifica-se através das falas destas mulheres o valor de pai como provedor, que se faz sentir pelas dificuldades financeiras que a família passa a viver e enfrentar diante da falta da tutela paterna e que se apresenta como fator desagregador da família.

Os significados atribuídos pelas mulheres à ausência da figura paterna seguem a visão tradicional dos papéis parentais em nossa sociedade em que o papel de provedor é exercido pelo homem como necessário nas camadas populares, conforme referem Alatorre e Luna (2005). Entretanto os mesmos autores sinalizam que tal papel é insuficiente, dado que existem outras tarefas consideradas próprias de pai: educar, ajudar nos deveres, brincar etc.

Referências às perdas da figura materna também se mostram evidenciadas nas falas destas mulheres; são perdas prematuras em que algumas nem chegaram verdadeiramente a conhecer a mãe.

Minha mãe morreu quando eu tinha 7 anos e meu pai foi embora quando eu tinha 7. Minha mãe morreu de ataque cardíaco. Ela bebia muito, um pouco foi a minha irmã, um pouco foi a bebida. $A$ minha irmã judiava dela, catava as coisas dela, xingava ela (o sujeito chora muito nesse momento). (S6) 
Até 5 anos eu morei com minha mãe e meu pai, depois ela morreu. Aí ficou só eu e meus irmãos mais velhos e meu pai. (...) Meu pai também deixava nóis. Ficava sozinha a noite inteira. Aí denunciaram ele, que não podia; já tinha arrumado até uma família pra dá nóis embora. (S9)

Quando a minha mãe era viva eu morava com ela. Quando ela morreu eu tinha 8 ano. Morreu meu pai e minha mãe. Aí eu fiquei pro mundo. (S10)

Minha mãe teve 14 filho... Então, quando ela teve eu, depois de três dias ela faleceu, bem dizer, de parto. (S1)

Tendo por base o mesmo universo de significado social em que as representações sobre os homens provêm predominantemente de relações ligadas à organização da produção, as das mulheres provêm das funções familiares relacionadas com vínculos pessoais e afetivos (CHODOROW, 1990).

Neste sentido é que a perda materna tem significado no campo afetivo das relações na família. Socialmente, é demarcada para as mulheres certas características e capacidades especificamente femininas, atribuindo ao sentimento materno um caráter "inato" e, portanto, compartilhado por todas elas. É assim que características biológicas - a maternidade inscrita no corpo feminino - passam a assumir um significado social. Ela se transforma em um "ser para os outros" (COUTINHO, 1994).

Enquanto os homens são reconhecidamente importantes à sobrevivência econômica da família, segundo refere Chodorow (1990), as mulheres, como mães, são agentes decisivos na esfera da reprodução social, pois são as que mais participam da educação, transmitindo aos filhos as ideologias vigentes na sociedade.

Estudos apontam os efeitos nocivos sobre a formação da criança quando observada num processo de separação dos pais e, em especial, da mãe (BOWLBY, 1988; SPITZ, 1979; WINNICOTT, 1993).

Spitz (1979, p.99) ressalta a importância do afeto na relação mãe-filho no aparecimento e desenvolvimento da consciência do bebê e a participação vital que a mãe tem ao criar um "clima emocional favorável", 
sob todos os aspectos, ao desenvolvimento da criança. Segundo o autor, são os sentimentos maternos que criam esse clima emocional que confere ao bebê uma variedade de experiências vitais muito importantes por estarem "interligadas, enriquecidas e caracterizadas pelo afeto materno".

Tais experiências são essenciais na infância, pois, nesse período, os afetos são de altíssima relevância, maior do que em qualquer outro período posterior da vida, visto que, do ponto de vista psicológico, grande parte dos aparelhos sensório, perceptivo e de discriminação sensorial ainda não amadureceram; como consequência, a atitude emocional da mãe serve para orientar os afetos do bebê e conferir qualidade de vida à sua experiência.

Ao nascer, o bebê é um ser indefeso e incapaz de sobreviver por meio de seus próprios recursos; o que the falta deve ser compensado e fornecido por um adulto cuidador. Para além dos cuidados de alimentação e higiene, vários autores ressaltam a necessidade do bebê de um contato afetivo contínuo advindo de uma figura constante - a mãe ou um cuidador substituto competente - com a qual estabelecerá relações de apego que vêm assegurar e favorecer seu desenvolvimento biopsicoafetivo (BOWLBY, 1984, 1988, 1989; GOLDSTEIN; FREUD; SOLNIT, 1987; SPITZ, 1979; SZEJ ER, 1999; WINNICOTT, 1993).

Quando a criança é privada de uma relação de afeto contínua, com a mãe ou mãe substituta permanente, ou seja, uma pessoa que desempenha, regular e constantemente, o papel de mãe, ela sofre uma série de efeitos prejudiciais descritos por Bowlby (1988) de acordo com o grau de privação. A privação parcial pode gerar angústia, exagerada necessidade de amor, fortes sentimentos de vingança e, consequentemente, culpa e depressão. Como a criança pequena não sabe lidar com estas emoções, sua forma de reação a tais perturbações poderão resultar em distúrbios nervosos, em uma personalidade instável.

$\mathrm{Na}$ ausência da figura paterna e materna, várias são as pessoas que podem oferecer suporte à família e ao indivíduo, promovendo, assim, uma melhoria na qualidade de vida daqueles beneficiados (BRITO-DIAS, 
1994; FERREIRA, 1991; LEWIS, 1987). Dentre elas, destacam-se os próprios membros familiares, outros parentes da família extensa (avós, tios, primos), amigos, companheiros, vizinhos e profissionais, que podem auxiliar de diversas maneiras: fornecendo apoio material ou financeiro, executando tarefas domésticas, cuidando dos filhos, orientando e prestando informações e oferecendo suporte emocional. Tal fato pode ser observado no relato das entrevistadas deste estudo.

Eu fugi com uma amiga minha pra casa da minha tia... depois eu voltei de novo e fui morar com uma mulher chamada Tereza e fiquei com ela dos 9 ano até meus 16 ano.(...) A Tereza é minha mãe de criação. Como eu não dei certo com minha vó nem com minha tia eu fui morar com a Tereza. Ela sempre me tratou bem. (S6)

Aí minha tia não deixou, que é irmã do meu pai. Pegou nóis pra criar eu tava com 6 anos. Eu fiquei morando lá até casar, até 18 ano. (S9)

Outro suporte social é a institucionalização das crianças e adolescentes, o que pode resultar na privação quase total de afeto, como observada, por vezes, em instituições de abrigos, creches e hospitais. Aumenta a severidade dos danos no desenvolvimento psicoafetivo, denominado "hospitalismo", sendo que a privação total, por sua vez, pode aniquilar a capacidade da criança de estabelecer relações futuras com outras pessoas.

As mulheres entrevistadas, contudo, não referiram em nenhum momento ter sido institucionalizadas quando crianças ou adolescentes, provavelmente, devido às leis de proteção a criança e ao adolescente serem recentes.

No Brasil, assim como em outros países, a colocação de crianças em instituições de abrigo tem sido considerada uma medida de proteção social legítima, prevista pelo ECA - regulamentado em 1990 - mas que deve ficar restrita a situações excepcionais, quando, por razões diversas, as condições postas para a convivência familiar forem inadequadas ou mesmo inexistentes. 
Enfatiza-se, neste momento, a importância da rede social, definida aqui como um sistema composto por “... vários objetos sociais (pessoas), funções (atividades dessas pessoas) e situações (contexto)" (LEWIS, 1987, p. 443), que oferece apoio instrumental e emocional à pessoa, em suas diferentes necessidades. Apoio instrumental é entendido como ajuda financeira, ajuda na divisão de responsabilidades em geral e informação prestada ao indivíduo. Apoio emocional, por sua vez, refere-se à afeição, aprovação, simpatia e preocupação com o outro e, também, a ações que levam a um sentimento de pertencer ao grupo (CRAIG; WINSTON, 1989).

Rutter (1987) e Zannon (1981) consideram o fato de separar o filho da mãe como responsável por estresse e prejuízo em seu desenvolvimento, assim como os seguintes fatores: qualidade das relações anteriores com a família, idade da criança, condições de estimulação ambiental e qualidade do cuidado dispensado a ela durante o período de separação. Os autores ressaltam, também, que não se pode visualizar a separação apenas do ponto de vista da "díade mãe-criança", mas é importante considerar a interação da criança com outros membros da família.

Assim, pode-se dizer que a separação não é, em si, necessariamente, um fator a perturbar o desenvolvimento da criança, mas a separação aliada à ausência de condições favorecedoras do seu desenvolvimento, como descrito pelos autores/autoras acima referidos.

\section{Convivendo com alcoolismo, pobreza e violência em família}

As falas destas mulheres retratam as condições desfavoráveis vivenciadas durante toda a sua infância e adolescência, incluindo vivências de uso abusivo de álcool e pobreza, deixando evidenciar famílias em situação de degradação. 
Meu pai não me criou, ele bebia muito, cada filho ele deu para uma família (...). (S1)

Eu tinha vergonha de contar pros meus amigos, né, do meu pai. Meu pai bebia, bebia muito, tipo alcoólatra.(...) Quando ele bebia ele ficava agressivo, batia na gente e na minha mãe, mas teve uma vez que nós não deixou ele bater nela não. (S3)

Meu pai fumava e bebia pinga também. Quando ele bebia ele ficava agressivo, chegou uma época que ele jogava comida fora, a gente tinha que esperar ele dormir pra poder entrar pra dentro, pra gente comer. Porque se ele via, ele jogava tudo fora pra gente não comer, mas não é que ele era ruim, a bebida é que deixava ele desse jeito.( S8)

Quando meus pais morreu nóis tinha uma casa de dois cômodo. A minha prima foi lá e vendeu a nossa casa, aí nóis ficou na rua. Fomos morar debaixo de uma mangueira, lá na Vila, lá em cima. Nóis ia na cidade com latinha e pedia comida e levava tudo pra debaixo da mangueira. (S10)

Aspectos de degradação familiar podem ser apreendidos nos relatos sobre a ocorrência da violência intrafamiliar como parte do cotidiano das famílias de origem destas mulheres.

A associação do alto consumo do álcool e práticas de violência tem sido objeto de estudo de autores. Segundo Rabelo e Caldas Junior (2007), o consumo de álcool ou drogas em larga escala no Brasil, principalmente por homens, manifesta-se em mudanças de humor expondo ao maior risco de praticar violência, principalmente contra as mulheres.

Vale considerar que, apesar de evidências empíricas, há muitas dúvidas quanto às explicações causais de uso de álcool e prática de violências. Para Minayo e Deslandes (1998) ainda não foi possível inferir que tal uso afete o comportamento das pessoas envolvidas e também não é possível discernir se o uso de drogas, estando associado a outros aspectos, desencadeia comportamentos violentos ou se é, por si, um fator causador.

Sobre a associação entre pobreza e violência, concordamos que o aumento dos níveis de miséria constitui fator importante para o crescimento da violência. No entanto, partilhamos da idéia de Gomes et al. (2002), que tal associação indiscriminada ou pode gerar uma 
criminalização da pobreza, colocando segmentos sociais inteiros como suspeitos ou na mira de permanentes julgamentos prévios.

A violência conjugal se mostra como fato que marcou a infância dessas mulheres. Na dinâmica das relações conjugais identificam-se pólos de subordinação e dominação. A divisão interna de papéis admite uma distribuição desigual de privilégios, direitos e deveres dentro do ambiente doméstico, setor em que se definem assimetrias de poder calcadas em diferenças de gênero.

A herança cultural do regime patriarcal, típico das sociedades ocidentais de influência judaico-cristã, media o convívio dentro do espaço privado dos casais, configurando o relacionamento cotidiano como gerador de uma complexa trama de emoções, em que a sexualidade, a reprodução e a socialização constituem esferas potencialmente criadoras de relações ao mesmo tempo prazerosas e conflitivas (AZEVEDO; GUERRA, 2000).

As agressões perpetradas pelo parceiro íntimo são mundialmente reconhecidas como uma das formas mais comuns de violência contra a mulher (WATTS; ZIMMERMAN, 2002), que apresenta maior risco de ser agredida física e sexualmente por quem convive intimamente com ela, do que por qualquer outra pessoa (GARCIA-MORENO et al., 2006).

Do ponto de vista legislativo, no Brasil, a Lei no 11.340, sancionada em agosto de 2006, estabeleceu como violência doméstica e familiar contra a mulher qualquer ação ou omissão baseada no gênero, que the cause morte, lesão, sofrimento físico, sexual, psicológico e dano moral ou patrimonial no âmbito da unidade doméstica, da família ou em qualquer relação íntima de afeto, na qual o agressor conviva ou tenha convivido com a ofendida, independentemente de coabitação (BRASIL, 2006a).

Abaixo, relacionamos algumas falas em que as mulheres entrevistadas colocam sobre a cotidianidade da violência conjugal entre seus pais biológicos ou substitutos, durante sua infância. 
...depois de três dias que minha mãe teve bebê, dizem que meu pai socou minha mãe de resguardo num latão de água gelada, passado de um dia pro outro. (...) dizem que ela deu hemorragia e outras coisas, choque com água gelada, da noite pro dia seguinte. (S1)

Meu padrinho brigava com minha madrinha, ele chegava a bater nela, ele bebia muito. Já entrei no meio de briga dele. Eu era criança e falei para meu tio parar de brigar com a tia. Ele ameaçava ela... Tem marido e mulher que briga e quebra tudo... (S2)

Observamos pelas falas destas mulheres que, dentre as causa de comportamentos violentos, além do uso de álcool - que se mostrou predominante neste grupo - também o dinheiro e o ciúmes são considerados fatores causais de conflitos conjugais manifestando em atos violentos.

... meu pai brigava muito com a minha mãe, por ciúmes das duas partes. (...) Meu pai agredia minha mãe e eu via. Eu era muito pequena, mas eu lembro mais ou menos: uma vez que ele bateu nela, porque ele saiu e ficou o dia inteiro fora de casa, ele tinha recebido. Ela ficou nervosa e quando ele chegou, pra agradar ela, ele chegou com uma manga e ela tava brava e ele esfregou a manga no rosto dela. Eles começaram a brigar e ele bateu nela. (S3)

No que tange ao ciúme, coloca-se como base as diferenças de gênero em que o agressor comete a violência com o intuito de manter sua superioridade, manter a mulher como sua propriedade.

Para a WHO (2005) a violência é o resultado da complexa interação de fatores individuais, de relacionamento, sociais, culturais e ambientais.

A respeito dos fatores desencadeantes da violência, estudo de Brito et al. (2005), sobre as características gerais das famílias de crianças e adolescentes vitimizados, observa que segundo os membros da família $58 \%$ acreditam que os conflitos do casal contribuíram para desencadear a violência, 51\% acreditam que foram as características próprias da criança ou adolescente, 49\% atribuem ao histórico de vida dos pais, 40\% associam a violência ao fato de ter dificuldades em colocar limites para seus filhos, $32 \%$ afirmam que o alcoolismo foi um dos fatores 
desencadeantes, $25 \%$ fatores socioculturais, $25 \%$ falta ou excesso de trabalho, $21 \%$ outros fatores e $9 \%$ outros tipos de drogas.

Independentemente dos fatores desencadeantes e dos casos particulares em que se evidenciam os conflitos intrafamiliares, a violência familiar afeta de uma forma geral a todos da família.

Além de presenciar violência conjugal entre seus pais, as mulheres entrevistadas também expõem o quanto sofreram violência, dos mais variados tipos, em sua infância.

As modalidades de violência doméstica, cometidas contra crianças e adolescentes, são classificadas em: violência física, violência psicológica, negligência e violência sexual. Essas modalidades podem ocorrer na forma pura, quando se trata de uma única modalidade de violência, ou associada, quando em um mesmo caso são identificadas duas ou mais modalidades (BRITO et al., 2005).

Percebemos nas falas, que a maioria das entrevistadas se lembra da infância como um período ruim devido às agressões física, sexual e psicológica sofridas.

De primeiro, eles não judiava de mim quando minha mãe tava viva, eles tinha medo da minha mãe. Aí depois que minha mãe morreu que eles judiavam de mim, eu fui morar com minha irmã, que também judiava de mim, ela tomava meus brinquedo e dava pros filho dela. Minha tia me batia, batia bastante. (S6)

Nós fomo criado numa infância muito ruim, ele bateu muito em nóis. (S7)

... ele amarrava nóis no fogão pra não escapar, sem blusa. Eu com 12 ano de idade, tava começando a criar peito, uma porque não tinha roupa e outra porque ele tirava nossa roupa pra bater em nóis. (S7)

As marcas deixadas pela violência doméstica na infância são muitas vezes subestimadas, por considerar seu impacto temporário e desaparecer no decorrer do desenvolvimento infantil. Entretanto, a agressão contra a criança/adolescente deve ser reconhecida como um sério problema e, mesmo que esses indivíduos vitimizados sejam retirados de suas casas, os efeitos da experiência vivida repercutirão por toda a 
vida. Tal condição pode ser observada pelas lembranças que estas mulheres trazem de seu passado de sofrimento.

Outro fato é evidenciado na fala de S1 e S7, em que a surra é um corretivo necessário para garantir a disciplina e obediência. Uma violência naturalizada em que a mão masculina deixa a marca da força e autoridade paterna.

\begin{abstract}
Meu pai sim tinha vezes que ele precisava me dar um corretivo, ele tinha que me corrigir, né. Ele que tinha a guarda, ele que pegou eu de papel passado, ele sim, ele me batia, eu era filha dele... Ele pegava o chicote, cinta, às vezes. Pra ir pra escola muitas vez eu ia na parte da manhã (...) ele me acordava com cintada pra me ir pra escola, porque o horário também não espera. (S1)

Ele tinha feito um rabo-de-tatu, tipo uma corda de couro trançado, tipo uma cinta e ele deixava reservado para bater em nóis, diz que era pra educar. Praticamente, quase matava nóis. Ele já chegou a amarrar nóis em rabo de fogão pra bater. (S7)
\end{abstract}

Às vezes, ela nem falava pro meu pai, porque ele era homem, né, e ela tinha medo dele machucar nóis. (S3)

Nesta direção observam Farinatti, Biazus e Leite (1993) que é difícil, avaliar o tênue limite entre os atos educativos e condutas violentas praticados contra a criança e o adolescente, uma vez que em nossa sociedade aplicam-se tradicionalmente métodos disciplinares físicos e verbais e, não, a persuasão, o diálogo e os exemplos.

Para Weber, Viezzer e Brandenburg (2004) a punição corporal parece eficaz no instante em que é aplicada, mas a longo prazo pode acarretar prejuízos não somente para o indivíduo que a recebe, mas também para os outros com quem convive, aumentando os índices de delinquência, criminalidade e violência contra o cônjuge.

Outra forma de violência no interior das famílias das entrevistadas foi a violência sexual. Identificamos na fala da entrevistada S7, que se mostra indignada com a atitude do padrasto, o qual abusou sexualmente de sua irmã dos sete aos 14 anos e também tentou abusar dela. 
esse homem, pelo próprio padrasto, começou com sete anos. Estuprou minha irmã com sete anos de idade, já era um homem velho com seus quase 40, né... Quando ela fez 14 ano ela tava grávida, ficou de sete a 14 anos sendo abusada, sem poder falar nada. (S7)

Ele começou a querer dar banho em mim com 12 anos. Eu acho que a mesma coisa que ele fez com minha irmã ele tava tentando fazer comigo. (...) Uma vez ele veio com uma segunda intenção comigo, meio que passando a mão no meu corpo, mas eu já era esperta, falei com minha mãe, mas ela falava que era mentira. (S7)

A respeito da violência sexual, Junqueira (2002) discorre que quando ocorre em uma fase precoce da infância, as crianças, por imaturidade no discernimento, sentem-se privilegiadas por terem uma atenção diferenciada, já que esse aparente “afeto" e aproximação são exercidos por pessoas de confiança, com quem elas iniciam o processo de socialização. A partir de seu desenvolvimento cognitivo, percebe-se manipulada e submetida a um jogo de abuso de poder, que transgride seus princípios e valores. Isto a coloca em uma situação de conflito, em que ora é vítima, ora é "agente indutora" da agressão e da desestruturação do lar, visto que o abusador acusa-a de tal, e a ameaça constantemente, a fim de manter o silêncio sobre essa relação incestuosa.

Alguns fatores, segundo a mesma autora, determinam a intensidade das repercussões do abuso na vida do vitimizado, dentre eles: a forma como a família reage diante do abuso intrafamiliar; a instituição ou não do tratamento psicológico/psicanalítico; a existência de redes de apoio para a retaguarda de proteção; os aspectos peculiares de cada cultura, além da resiliência de cada vitimizado na superação da violência.

Afora a violência psicológica e as lesões físicas e genitais sofridas, as crianças e adolescentes vítimas de abuso sexual tornam-se mais vulneráveis a outros tipos de violência, aos distúrbios sexuais, ao uso de drogas, à prostituição, à depressão, ao suicídio e a fator de risco para um comportamento delinquente, com uma maior prevalência entre abusadores sexuais reincidentes (SWANSTON et al., 2003) e com risco de, no futuro, passarem de agente violado à agente violador. Enfrentam, 
ainda, a possibilidade de adquirirem o Vírus da Imunodeficiência Humana (HIV), outras doenças sexualmente transmissíveis, e o risco de uma gravidez indesejada, decorrente de estupro.

Outra forma de violência apresentada pelas mulheres é que a maior parte das entrevistadas referiu ter trabalhado durante a infância, o que as privou da possibilidade de frequentar a escola ou mesmo de viver a infância.

Eu ganhava o dinheiro e dava na mão dela, da manga.(S2)

Na roça, nós carpia algodão, fazia muita coisa. De primeira podia criança, né. Eu ia com uns dez anos já. Às vezes eu achava bom ir, mas às vezes eu não queria ir porque eu ficava com preguiça, a gente levantava muito cedo né, mas eu ia assim mesmo. (S3)

Me levantava todo dia de madrugada pra eu ter que encher garrafão d'água, pra eu ajudar ela com a comida, a marmita. Isso eu tinha uns 11, 12 anos, era só eu. Quantas e quantas vezes, lembro como se fosse hoje, ele me cutucando pra eu acordar, com estupidez, é uma coisa que eu odeio até hoje.(S4)

... aos 8 anos de idade eu fui pra roça trabalhar. Nóis não teve infância boa não. Foi trabalhar na roça, não tive escola e daí por diante. (...) Nóis trabalhava a semana inteira, chegava no sábado ele (padrasto) juntava o dinheiro, enchia a carteira de dinheiro nosso e ia pra zona gastar o dinheiro tudo.(S7)

...meu pai e minha mãe ficou doente e nóis teve que trabalhar pra tratar da minha mãe e do meu pai. Eu ia pra roça catar algodão, com sete ano já ia pra roça já. (S10)

Mesmo em face do grandioso desenvolvimento tecnológico possibilitado pela eletrônica e informática, observado no mundo contemporâneo, uma verdadeira chaga social surgida desde o século XVII, a exploração de mão-de-obra infantil em atividades produtivas persiste em se fazer presente. Dada como erradicada no início do século $X X$, nos países de capitalismo central como a Inglaterra e Estados Unidos, desde o segundo quartel desse mesmo século vários estudos e instituições denunciam a reincidência da situação, em que pesem algumas mudanças de feições.

Nos países em desenvolvimento, por um lado, em decorrência das ações capitaneadas pela Organização Internacional do Trabalho (OIT), 
no contexto das quais se aponta para a erradicação do trabalho infantil, as estatísticas oficiais revelam diminuição do número de crianças no trabalho.

Contudo, por outro lado, muitos estudos têm dado conta das renovadas formas de inserção das crianças no trabalho não apontadas nas pesquisas levadas a cabo pelos governos, de modo que se avalia de maneira geral crescente o número de crianças trabalhando no setor produtivo e de famílias que requerem o trabalho das crianças para sobreviverem.

Como referido, a configuração de uma parcela significativa da força de trabalho infantil é devida a necessidades geradas no seio familiar, decorrentes das insuficientes condições de sobrevivência. Porém, observase que tanto as famílias quanto outros setores da sociedade atrelam às justificativas de teor econômico razões de caráter subjetivo para estimular, encorajar as crianças a, cedo, ingressarem em alguma atividade produtiva. Ao se tratar de certa parcela dos adolescentes, então, observa-se a defesa intransigente do direito e da importância do trabalho produtivo, na maior parte das vezes em detrimento de atividades esportivas, estudantis, dentre outras, ainda que o trabalho desenvolvido represente sério dano físico ou mental.

Associado à realidade social e econômica, o apoio familiar à inserção precoce no trabalho produtivo subsiste a despeito da legislação que coíbe a contratação e o exercício desse tipo de atividade por crianças, e a tantos programas de atendimento voltados para essa população. Toda a proibição e evidência das consequências nefastas do trabalho precoce não têm sido suficientes para fazer estancar o crescimento dos índices das novas vítimas flagradas no trabalho doméstico, na agricultura, nas atividades terceirizadas e domiciliares.

Na condição de criança, diante da violência seja para com ela ou para com outro membro da família, pouco ou praticamente nada esta pode fazer, como bem observa a entrevistada S3 sobre a condição de 
enfrentamento da violência perpetrada pelo pai para com a mãe e para com os filhos, em que a contra-reação só se concretizou na fase adulta.

\begin{abstract}
Quando ele bebia ele ficava agressivo, batia na gente e na minha mãe, mas teve uma vez que nós não deixou ele bater nela não. (...) Ele foi pra bater nela, nós já tava grande, e nóis bateu nele também. Aí depois ele nunca mais pôs a mão nela, pelo menos pra nós ver, não. A hora que ele foi bater nela, minha irmã mandou uma pedra nele que pegou na testa dele, ele tem a marca até hoje. Foi um tiro certeiro, ela nem era boa de mira, parece que foi uma coisa que levou a pedra. (S3)
\end{abstract}

A fragilidade da criança a torna vítima certeira, sem chance de resistência. A este respeito Sanchez e Minayo (2006) referem que os maus tratos têm diferenças hierárquicas, ou seja, as crianças acabam sendo as maiores vítimas, já que suas fragilidades físicas e de personalidade as tornam alvos fáceis de raiva, ressentimento, impaciência e emoções negativas, funcionando então como uma "válvula de escape"

\title{
Convivendo com afetos e desafetos: "eu achava tão bom, tão gostoso quando ela me chamava de filha, era muito raro, muito raro"
}

O contexto familiar e social em que viveram as mulheres entrevistadas, durante seu processo de socialização na família de origem, reúne fatores que contribuem para dissociações importantes quanto a referencia materna.

Enfatiza-se que a família é culturalmente compreendida como círculo de acolhimento e de cuidado. A família ocupa a instância diferenciada quanto à proteção deste grupo etário, pois é através do convívio e do cuidado que se projetam as relações e os valores sociais.

Mediante a convivência afetiva, a pessoa pode assimilar tanto os múltiplos limites, quanto as diversas possibilidades de cooperação, de aceitação e tolerância. Entretanto, aqueles que deveriam ser os 
responsáveis pelo cuidado e suporte assumem o papel de agressores, rompendo ou fragilizando ainda mais a relação de confiança da criança e do adolescente.

A sobrevivência da criança depende da proteção, atenção e cuidados prestados pelo adulto; nesse sentido, a relação de apego desempenha a função de garantir o recebimento desses cuidados.

Baseado nessa abordagem e na teoria da evolução e da psicologia cognitiva, Bowlby (1989) desenvolveu a teoria do apego, que postula a existência de uma organização psicológica interna situada no sistema nervoso central, responsável pela formação e manutenção dos laços emocionais íntimos entre indivíduos. A propensão para estabelecer tais laços é considerada um componente básico da natureza humana, encontrando-se presente no neonato em forma germinal, e continuando na vida adulta e velhice, quando os primeiros laços persistem e são complementados por novos.

Além do motivo primordial de sobrevivência, Bowlby (1989) ressalta a influência no desenvolvimento da criança, em termos de saúde mental, da maneira como a criança é tratada por seus pais - sobretudo pelo cuidador principal que, em sociedades ocidentais, geralmente é a mãe.

A vivência de uma relação calorosa, íntima e contínua com a mãe ou mãe substituta permanente, ou seja, uma pessoa que desempenha, regular e constantemente, o papel de mãe, mostra-se essencial à saúde mental da criança. É essa relação complexa, rica e compensadora com a mãe, nos primeiros anos de vida, enriquecida de inúmeras maneiras pelas relações com o pai e familiares, que a comunidade científica julga estar na base do desenvolvimento da personalidade e saúde mental (BOWLBY, 1988). As falas das entrevistadas, a seguir, vão de encontro à boa relação mãe-filho descrita na literatura: 
Me lembro que minha mãe vivia batendo em mim, porque eu era responsável pelos outros dois, se os outros dois fizesse alguma coisa, era pra cima de mim que vinha. Ela me dava cintada, chinelada. Antigamente podia né, hoje em dia não pode. (S4)

S4 relata sobre as surras que sofria durante sua infância, em razão da desobediência frente à ordem de cuidar dos irmãos. Traz também a idéia que perpassa nos momentos atuais de que surras corretivas são atualmente proibidas por se caracterizar como violência física. Para além da discussão do corretivo como forma de violência ou não, o que recomendam os estudiosos no assunto é que as agressões físicas deixam marcas negativas em longo prazo, tornando-se evidentes as vantagens das práticas educativas sem punição corporal, tal como o diálogo. Este, além de ajudar no desenvolvimento de habilidades sociais dos filhos, mantém uma dinâmica familiar com responsividade, afeto e comprometimento (WEBER; VIEZZER; BRANDENBURG, 2004).

Os reflexos em longo prazo podem ser apreendidos nas falas destas mulheres, que se lembram da figura materna com certa mágoa; o que se expressa em carência afetiva, negligência nos cuidados e em um relacionamento mãe-filha distante. Ainda falam da agressividade de suas mães: "ela espancava também".

Eu não tenho muita lembrança boa da minha mãe não, tanto é que, pode ser pecado, mas eu não sinto muita falta dela. Vai fazer anos que eu não vejo ela, porque o que mais me marcou foram às lembranças ruins. Pra dizer a verdade eu achava tão bom, tão gostoso quando ela me chamava de filha, era muito raro, muito raro. Geralmente ela mandava, não pedia, sempre brava. (S4)

Às vezes que minha mãe bateu em nóis foi muito pouco, mas ela bateu mesmo, quase igual ele. Ela não corrigia não, ela espancava também. (S7)

A mãe é diferente, né, ela já batia, já dava uma sacudida. Tem mãe que não sai pegando pra bater porque se pega pra bater... Ela batia de cinta, espada de São Jorge, com a mão. (S8)

Minha mãe não tinha um relacionamento legal com a gente não. Até ela começar a ter família desse outro homem, ela era uma mãe normal. Se você tem família de um homem e de outro você trata todo mundo igual, pelo menos eu sou assim. O amor de mãe é um só e ela não, ela fez diferença. (S7) 
Sob as bases do que consideram não ser uma boa mãe, revelam uma infância marcada por buscas constantes de uma referência materna. Tal referência é exemplificada por aquela mãe que não bate, que se preocupa, que cuida, que tem amor pelos filhos sem fazer diferenças.

Minha relação com minha mãe era boa, ela não me batia. (...) Minha vó judiava de mim também, ela me batia muito. (S6)

Nosso relacionamento era tudo bem, nunca brigou, ela (madrinha) que criou eu, era uma mãe mesmo. (S2)

Minhas tias não tinham mania de bater, elas falavam, elas conversavam, mas essa mania de bater igual a gente vê muito por aí não. Dava uma chinelada, não era espancamento. Eu brinquei muito pouco de casinha, sair elas não deixavam (S9)

Na trajetória de busca por um modelo de relação mãe e filho evidenciam-se movimentos de resistência ou até mesmo de rebeldia ante a situação em que vivenciaram durante a infância. Dentre as formas de lidar com as situações incluem-se os questionamentos sobre a sua paternidade, a indiferença para com as atitudes maternas, indisciplina e até tentativas de suicídio.

Minha mãe, o problema dela era mesmo só quando ela bebia. Ela não olhava de mim, ela ficava mais é com os amigo dela, mas pra mim não fazia diferença, porque eu ficava mais era com a minha vó. (S6)

Eu morava com meus pais, nosso relacionamento não era bom. (...) Às vezes eu chegava em casa, minha mãe me batia, ia atrás de mim na rua, me levava pra casa mas eu saia de novo. Na rua eu tinha os amigo, bebendo, fumando.(S5)

Eu até cheguei numa época a questionar se eu era filha deles mesmo, se eu não era adotiva, porque era demais. Pela diferença que ela fazia comigo. Meu irmão principalmente era o que ela mais paparicava, homem, caçula. (...) minha mãe, tudo que ela ficava sabendo, ela acreditava nos outros e não em mim. Aí foi juntando tudo e eu peguei um monte de comprimido e tomei, só me lembro que eu tava desmaiada, ela foi lá me chamar, pegou o meu braço e meu braço caiu, aí já chamou o vizinho e me levou pro hospital. Aí depois foi pior, ela me jogava na cara o que eu tinha feito.(S4)

Minha tia quando eu chegava bêbada mandava eu dormi, pra não ter mais confusão, mais briga. No outro dia, ela chamava eu a atenção, que isso não era coisa de fazer, moça chegar altas horas da noite embriagada, que era perigoso.(S1) 
A análise do conjunto de situações vivenciadas pelas entrevistadas em suas famílias de origem nos coloca frente a uma complexa rede de fatores que, conjuntamente ou separadamente, vão refletir na identidade social dos membros da família, particularmente nas crianças e adolescentes que estão em processo de socialização.

\subsubsection{O contexto da família atual: repetindo trajetórias de vida}

\section{“Eu tentei construir uma família... bem ou mal ela tá aí"}

Diante de situações difíceis na família de origem, algumas entrevistadas optaram por iniciar uma nova família, repetindo o mesmo padrão de família desestruturada.

Eu enrolei minha vida com 13 anos, precisei fugir com o namorado, pra não ser abusada por ele (o padrasto) dentro de casa. O meu namorado eu nem conhecia direito, porque a pessoa pra viver com outra tem que conhecer muito, né. Primeiro você tem que saber quem ele é pra depois você casar. (S7)

Aí o pai dos meus filho chamou eu pra fugir com ele (...) Ele falou pra mim que era pra eu fugir com ele que ele ia me tirar da rua e dar um lugar pra mim morar. (...) Só que aí eu nem dormia com ele, ele pegou eu pra dormir com ele só depois de muito tempo, ele só cuidava. Eu tinha nove anos. Quando ele me chamou pra ir morar com ele, eu pensei: 'vai ser melhor, ele vai me dar comida, vai me dar um lugar pra mim morar'. Ele deu roupa pra mim, trabalhava panhando manga, alugou uma casa de 3 cômodos, comprou uma cama, comprava sapato pra mim. Mas eu não tinha um pingo de juízo. Ele era mais velho do que eu. Eu tinha 14 anos na primeira gravidez, meus nove filhos é dele. (S10)

Identificamos que tanto a entrevistada S7 como a S10 tomam decisões arriscadas e por vezes inconsequentes, mas, que naquele momento da vida lhes pareceu a única oportunidade fugir da condição 
desfavorável em que viviam, ou seja, o risco da violência intrafamiliar ou mesmo da condição de miséria de ser uma moradora de rua.

Questiona-se quanto o contexto de vida foi decisivo na tomada de decisão, bem como o peso do modelo de ser mulher na família de origem, evidenciando um atravessamento intergeracional pelo processo de socialização, aliado à experiência singular no âmbito das relações familiares.

Um olhar atento para como estas mulheres se identificam como seres sociais parece assentar-se na naturalização das atribuições e estereótipos sexuais. Neste sentido, seu projeto de vida limita-se a conceber uma nova família através do casamento ou união consensual, na busca de fugir da realidade que se apresenta como desfavorável e, ao mesmo tempo, pela contingência de estar grávida.

Eu acho que eu casei pra sair fora de casa. (...) Era muita dificuldade, muita coisa sobrava pra mim, minhas irmãs não ligavam pra nada (S9).

Eu casei por causa da família, eu não casei, assim, porque sou mulher e tenho que ser uma boa companheira e casar e construir família. Eu engravidei do menino... Minha família me obrigou a casar com ele, não queriam mãe solteira, minha tia não aceitava (S1).

Eu ficava pensando que na minha casa poderia ser diferente, né. Se na família dos outros também tinha isso também. A gente acha que a família dos outros é perfeita. Quando eu fiquei mais velha eu vi que toda família tem problema (...) Meu relacionamento com meu marido nunca foi bão, morei mesmo com ele depois que nasceu as crianças. (S3)

Identificam-se na fala da entrevistada S1 aspectos da construção social de transmissão transgeracional. A compreensão dos papéis femininos na dinâmica familiar teve importante contribuição da sociologia nos anos 80, em que se discutiu a exploração do trabalho e identidade femininas no espaço da produção capitalista e no espaço doméstico. $O$ espaço doméstico constitui um locus de poder dentro da sociedade cuja unidade de prática social são os sexos, a forma institucional é o casamento e o mecanismo de poder, o patriarcado (SANTOS, 1996). 
A condição de pobreza é uma realidade que se mantém na vida destas mulheres:

Eu ganho essa renda que é do governo, o bolsa família, ta $R \$ 122$ com mais esse servicinho que eu faço, dá uns $R \$ 200,00$ por mês. A mala de roupa ta $R \$ 30,00$ e elas não te dão um pão duro pra vc trazer, eu que compro o sabão. A faxina é 50 em Ribeirão. Meus filhos tem vez que praticamente fica sem leite no fim do mês, sem uma gota.(S7)

...fui no juiz e pedi pra ele pôr meus filho na Casa Abrigo, precisei perder meus filhos quase 1 ano, porque eu tava vivendo junto com minha mãe, meus filho tava sendo maltratado, às vezes não tem comida pra comer. Nesse intervalo eu ia trabalhar pra vê se eu fazia a minha casa, eu já tinha o terreno. (S7)

Dez dias atrás eles ficaram sem jantar; eles ficaram 2 dias sem almoçar e sem jantar porque não tinha comida. Não tinha um gás, não tinha força. (S9)

Sobre as formas como a pobreza tem influência na degradação da família ou mesmo no maior risco a ocorrência da violência, observam Cavalcante e Goldson (2009) que esta questão deva ser amplamente considerada em seus fatores associados, ou seja, com as profundas desigualdades associadas à pobreza. Para estes autores, as formas de se lidar com a pobreza e deficiência envolvem considerar aspectos relacionados às causas estruturais (exclusão social, recursos limitados, baixas expectativas, isolamento social, falta de apoio) que interagem com as causas pessoais e imediatas (nível de saúde, educação, competências, habilidades, auto-estima) que produzem privações múltiplas. Diferentes dimensões da pobreza, relacionadas com a educação, saúde, habitação, infraestrutura ambiental, condições de emprego, renda, bem-estar emocional, entre outros, interagem entre si produzindo diferentes tipos de privações que afetam negativamente as pessoas de forma intergeracional.

A privação do alimento é a realidade mais premente, o que parece se constituir nestas famílias uma condição de pobreza crônica, em que Ihes faltam habilidades de enfrentamento e estratégias de resiliência para lidar com a realidade apresentada. 


\section{“Minha vida da infância ao casamento parece que foi igual (...) continuei sendo agredida"}

Nas distintas trajetórias de vida das mulheres entrevistadas encontramos pontos em comum, os quais convergem entre si e podem ser definidos em certo denominador: mulheres que, mesmo provenientes de diferentes famílias, tiveram suas vidas marcadas por sujeição. Fatores associados a esta condição ganham status, podendo tornar crônica a violência intrafamiliar.

De maus-tratos na infância e adolescência na família de origem, as mulheres passam a conviver com a violência de gênero que, pelas falas destas mulheres, 100\% estão em situação de violência.

Violência de gênero "envolve ações ou circunstâncias que submetem unidirecionalmente, física e/ou emocionalmente, visível e/ou invisivelmente as pessoas em função de seu sexo" (NARVAZ; KOLLER, 2006).

Ele então começou a me trair, era agressivo, me batia muito. De resguardo da minha filha precisei ir pro hospital porque ele quase me matou, quebrou meu braço na pura pancada. (S7)

Fora as ameaça que o marido fala que vai me matar, mas já me agrediu muitas vezes, me batia demais, quando nóis bebia. (S1)

Ele me bateu uma vez que eu tava grávida da minha menina, ele me chutou e me deu um empurrão e eu quase caí no chão, porque eu não queria que ele fosse morar com essa mulher.(S5)

A violência conjugal tem sido entendida como violência contra a mulher cometida pelo parceiro no contexto de uma relação afetiva e sexual, independentemente de ser relação estável legalizada (RAVAZZOLA, 1997, 1999). A violência conjugal pode ocorrer tanto no espaço doméstico quanto no espaço urbano. A categoria de violência conjugal abarca as formas de violência física, sexual e violência emocional ou psicológica (CORSI, 1997, 2003). Uma vez que, nas relações conjugais violentas, os agressores são predominantemente do gênero masculino, e 
as principais vítimas, do gênero feminino, a violência conjugal é também uma forma de violência de gênero (NARVAZ, 2002).

Dentre os fatores associados à sujeição feminina está o consumo abusivo de álcool como detonador dos conflitos conjugais, vivenciado pela maioria das mulheres deste estudo.

No início do casamento, há 19 anos, eu sofri muito com ele, porque nós dois bebia, nós brigava e eu saía pior que ele.(S1)

(...) ele tava bebendo, ele me batia, me judiava, me largava passando fome (...). (S3)

Minha relação com meu marido não é daquelas boa não, nóis briga demais. Uma que ele bebe, faz coisa que eu acho que não deve fazer, fica andando com pessoas que mexem com droga. (S9)

A este respeito estudos têm apontado que mulheres vítimas de abuso físico ou sexual associado ao alcoolismo na infância tendem a se casar com homens alcoolistas (CESAR, 2006). Tal fato foi observado por esse autor que verificou nos depoimentos das mulheres, sujeitos de seu estudo, a impossibilidade de construir relações mais duradouras com companheiros que não tenham problemas de alcoolismo. A maioria delas teve contato com a bebida muito cedo e conviveu com amigos e amigas também alcoolistas, o que propiciava a relação com uma pessoa que bebesse.

A realidade da violência vivenciada entre os parceiros neste estudo mostra a possibilidade de agressões frequentes e vai, ao mesmo tempo, ao encontro da afirmação de Krug et al. (2002), que apontam não ser raro as mulheres sofrerem comumente vários tipos de agressão ao longo de suas vidas.

Identifica-se, ainda, uma submissão e sujeição ao homem em troca de seu sustento e dos filhos:

Me senti muito humilhada, eu tava errada por ter posto outro homem dentro de casa, mas eu tava sem comida dentro de casa, sem dinheiro.(S1) 
A desigualdade de gênero constitui uma das grandes contradições da sociedade que se mantém ao longo da história da civilização e tem colocado as mulheres em um lugar social de subordinação. Essa desigualdade tem como uma de suas extremas formas de manifestação a violência contra a mulher, que é resultado de uma assimetria de poder, traduzida em relações de força e dominação, como as entrevistadas descrevem acima. Desse modo, a violência baseada no gênero tem se constituído em um fenômeno social que influencia sobremaneira o modo de viver, adoecer e morrer das mulheres.

Em pesquisas de base populacional, realizadas em todo 0 mundo, entre $10 \%$ e $64 \%$ das mulheres afirmaram terem sido objeto de agressão física por parte do parceiro masculino em algum momento de sua vida (ORGANIZAÇÃO PAN-AMERICANA DE SAÚDE, 2003). A violência contra a mulher pode se manifestar de vários modos e em diferentes graus de severidade.

...sabe aquelas borracha de jogar água? Ele me bateu tanto, acho que até hoje eu tenho o sinal, as costas, então. Eu não aguentava nem andar, você andava parecia que tava abrindo. (...) Acho que eu comecei a gritar tanto que ele parou de bater, eu fiquei tudo marcada. Eu aprendi uma coisa, quando tiver falando deixa falar. (S8)

Aí ele (ex-marido) e um amigo dele juntou os dois pra me bater. Ele me empurrou e me jogou no chão, saiu me arrastando pra um lugar escuro e começou a me bater, me deu murro, me deu chute, tudo. Esse dente aqui é mole até hoje, desse dia. Aí eu tava grávida e perdi (...). Aí ele catou eu pelos cabelos e saiu me arrastando e depois me soltou. Aí eu cheguei em casa, tava nem conseguindo andar.(S6)

Segundo Minayo (2005, p.14),

suas formas mais atrozes e condenáveis geralmente ocultam outras situações menos escandalosas, por se encontrarem prolongadas no tempo e protegidas por ideologias ou instituições aparentemente respeitáveis.

Porém, essas formas de violência consideradas mais sutis, silenciadas no interior das relações conjugais, causam tantos ou mais danos às mulheres que suas formas de manifestações mais visíveis. 
Concordamos com Narvaz e Koller (2006) quando referem que o fenômeno da violência contra as mulheres acarreta sérias e graves consequências não só para o seu pleno e integral desenvolvimento, comprometendo o exercício da cidadania e dos direitos humanos, mas também o desenvolvimento socioeconômico do país. Acreditamos que essa violência não é mais uma questão privada, mas objeto de preocupação social.

Partindo do fato de que a violência afeta significativamente o processo saúde-doença das mulheres, podemos considerar o setor saúde como locus privilegiado para identificar, assistir e referir as mulheres vitimizadas. Ao longo de suas vidas, as mulheres que vivenciam violência de gênero apresentam mais problemas de saúde, geram mais custos de atenção sanitária e buscam, com mais frequência, os serviços hospitalares e de urgência que outras pessoas que não sofrem maus tratos (ORGANIZAÇÃO PAN-AMERICANA DE SAÚDE, 2003).

Eu tenho problema de coração, não posso trabalhar. Tenho angina,
fiz vários exames, sabe. Agora vou ter que fazer uma cirurgia
também, isso ta me deixando mais nervosa, não consigo dormir.
Vou ter que tirar um cisto, fazer um levantamento de bexiga.
Tenho problema de pressão alta, era muito alta. Agora eu tomo
um AAS, um remédio pra dor, tem noite que eu passo acordada
com dor. (S9)

Nos serviços de saúde, muitas vezes, evidenciam-se aspectos cujas interseções potencializam os efeitos da violência e ampliam seu campo de atuação: um deles diz respeito ao fato de a mulher não denunciar a agressão sofrida, seja ela física ou psicológica, apresentando apenas queixas vagas e recorrentes nos serviços de saúde, referentes aos danos físicos.

Quando nós começamos a separar ele me agrediu, eu não fui para o hospital porque eu tinha uma vizinha que era muito boa, ela me falou pra ficar na minha e deixar ele quieto.(S5)

Em contrapartida, muitas vezes a denúncia é feita, porém há uma frustração devido à falta de resolubilidade do sistema. 
Outras vezes, mesmo quando a situação de violência é diagnosticada, ela não é devidamente valorizada, pois o saber instrumental que orienta as práticas profissionais está voltado para tratar, sobretudo, os danos físicos. Todavia, questões subjetivas como a vulnerabilidade emocional e a desproteção são sentimentos que afetam a saúde mental e fragilizam a capacidade das vítimas de violência de gênero para o enfrentamento do problema. Este é extensivo ao espaço público, quando, por exemplo, a mulher não consegue nem mesmo verbalizar, para um profissional que a atende, que é vítima de violência doméstica. Desse modo, a inadequação do saber instrumental constitui um óbice para o desenvolvimento de um processo de trabalho transformador da realidade (SILVA, 2003).

\footnotetext{
Denunciei ele várias vezes, mas até hoje não deu nada. Ele já me jogou óleo quente, fui lá na cadeia mostrei, eu grávida desse aqui. Fui na polícia e não adiantou nada, denunciei, falei. Já perdi um porque ele e a mãe dele me bateu. Já perdi outros dois porque ele me bateu também.(S6)
}

Depois, há o fato da predominância de uma qualidade tradicional da assistência pautada por heranças de programações de saúde e formação profissional fragmentada e biologicista. Há, ainda, a influência do modo como foram construídas as identidades de gênero, impregnadas de estereótipos que designam, para as mulheres, lugares de obediência e submissão. Esses três aspectos interrelacionados na dinâmica da realidade social produzem a invisibilidade do impacto da violência sobre a saúde das mulheres.

Sendo a violência um problema de múltiplas faces, que tem suas raízes na construção histórica, cultural e social das relações de gênero, sua prevenção deve se fundamentar na desconstrução e reconstrução dessas relações perante os indivíduos, as famílias, as comunidades e a sociedade como um todo, para que se possam elaborar e desenvolver estratégias eficazes de prevenção e enfrentamento e tornar possível levar essa compreensão aos espaços sociais, em que a violência é construída e legitimada. 


\section{"Eu bato nele sim (...), mas em vista do que eu fui tratada, eu trato ele muito bem"}

Historicamente através da maternidade é que as mulheres foram elevadas à condição de ser social. Neste sentido, a identidade e subjetividade femininas tradicionalmente se mostram atreladas à maternidade e ao espaço privado do lar e da família. Tais construções históricas e sociais tendem a ser retomadas quando se atém a visão ideológica de mãe em nossa sociedade, conforme significam as mulheres deste estudo ao falarem sobre o sentido da maternidade para elas.

Eu gosto de ser mãe. Bom de ser mãe é quando você pode dar tudo, mas ele é arteiro demais, ninguém suporta ele. (S6)

Ser mãe é tudo de bom, tem a parte ruim, mas a parte boa apaga tudo. (...) Chegou uma época que quando eu perdi meus filhos por causa da bebida, eu não podia levar minhas crianças em lugar nenhum, tinha que ver meus filhos lá, me senti uma bandida..(S4)

O imaginário social da maternidade construída no passado e reafirmada ao longo dos tempos nas sociedades ocidentais, tem-se mantido fossilizado e estereotipado na atualidade, conforme observa Parker (1997). É possível depreender na sociedade contemporânea que tal ideário de maternidade parece manter-se apenas no discurso, não servindo de guia para as mulheres exercerem seu papel materno.

Aspectos desta construção histórica social feminina estabelecem que, por natureza, a mulher reúne características essencializada e universalizada de ser uma criatura generosa, abnegada e instintivamente mãe, ou seja, de dispor-se a fazer qualquer sacrifício por seus filhos. No conjunto das atribuições maternas constrói-se para a mulher, segundo Almeida (1999), o "perfil de mulher-suporte", em razão das incumbências sociais de educar e transmitir a ordem moral e social. 
Ancoradas neste ideário de maternidade é que as mulheres deste estudo deixam evidenciar um certo consenso do que consideram como seu papel materno: cuidar e educar.

Eu ponho eles na escola, eu busco, eu dou banho neles, ponho pra dormir; se não, ponho pra assistir desenho, dou uma caneta, um caderninho pra eles escrever em casa. Eu me preocupo com eles em relação a roupa, sapato, em ter as coisas pra eles. (S5)

Quando eu trabalho é só pra ele, eu não compro nada pra mim. Quando eu era criança eu não tive isso. (S6)

Eu preocupo com os pequenos de deixar sem as coisas. Eu luto pra não deixar eles sem o que comer, pelo menos o básico (...). O que eu acho disso é o pai vivendo com a mãe, respeitando a mãe, dando bom exemplo pro filho, os dois mostrando o que há de melhor pro filho. (S7)

A gente tem educar um filho quando o cipó tá verde, depois que madurar não adianta... (S2)

Depreendemos que o sentido de cuidar para estas mulheres, em sua essência, se volta a necessidades básicas de prover alimento e vestuário. Identificamos também, embora com menos evidência, uma preocupação em proporcionar um ambiente familiar de respeito e de dar estudo.

Sobre o cuidado, Collière (1989) considera que este surgiu juntamente com a humanidade, constituindo fator responsável pela continuidade da vida e permitindo, portanto, que continuemos vivos. Através do cuidado é que se proporcionam condições imprescindíveis à manutenção da vida, como a alimentação, o vestuário e a habitação.

O cuidado desenvolve-se através de tarefas organizadas de forma distinta entre os gêneros, dicotomizando, dessa forma, o cuidado entre o feminino e o masculino (COLLIÈRE, 1989). O cuidar atribuído à mulher não é biológico nem natural, mas construído socialmente.

$\mathrm{Na}$ divisão das tarefas entre os gêneros, historicamente definiuse para a mulher organizar a morada para a subsistência da família, repassar ensinamentos e hábitos, cuidar da alimentação e do vestuário, manter tradições, usos e costumes, perpetuando o saber adquirido de 
geração para geração (COSTA, 2004). Ao homem cabe a responsabilidade de provedor da família.

Sobre o papel de educar os filhos no interior das famílias, historicamente, se observa o mesmo preceito dicotômico entre os gêneros. A este respeito Wagner et al. (2005) alude que educar os filhos sempre foi uma tarefa complexa para os pais, embora isto não signifique que tais responsabilidades sejam compartilhadas de forma igualitária entre o casal. Da década de 1930 até meados da década de 1980, os pais geralmente desempenhavam suas tarefas educativas baseados na tradicional divisão de papéis segundo o gênero.

Em função da transição entre o tradicional e o moderno, a família encontra-se imersa em um certo mal-estar no que se refere à transmissão de valores aos seus membros (BUCHER, 1999). Há necessidade de mudança nas relações basais parentais, ou seja, o importante papel da profissionalização feminina impulsiona a reestruturação familiar, bem como mudanças dos estilos parentais maternos e familiares (BAPTISTA, 1995; BEM; WAGNER, 2006).

Estudos brasileiros com famílias de nível socioeconômico médio, nas quais a mulher é a principal responsável pelo sustento financeiro, mostram que ela ainda assume quase totalmente a responsabilidade pelas tarefas domésticas (WAGNER et al., 2005). Tais autores citam que as mulheres contribuem com $64 \%$ do total de horas de trabalho doméstico, enquanto os maridos cumprem apenas $30 \%$ das tarefas, sendo o restante executado pelas crianças. Constataram que $90 \%$ dos homens e $69 \%$ das mulheres trabalhavam fora e que, percentualmente, as mães conviviam mais com os filhos. A pesquisa também encontrou que $75 \%$ das tarefas são compartilhadas (dar limites, ir à escola, ensinar hábitos de higiene, sustento financeiro, dar suporte afetivo aos filhos e acompanhar em atividades de lazer), e que o restante é desenvolvido apenas pelas mães (auxiliar nas tarefas escolares e cuidar da alimentação). Já entre as americanas casadas, Gilbert e Brownson (1998) encontraram que 63\% das mães de crianças abaixo de seis anos de idade estavam trabalhando 
fora e que este índice aumentava para $71 \%$ quando a idade dos filhos também aumentava. Além disso, apontaram que as mulheres que trabalhavam em tempo integral contribuíam com $40 \%$ da renda anual familiar. Entre essas mães trabalhadoras, $27 \%$ deixavam seus filhos em pré-escolas ou creches, 39\% utilizavam os serviços de parentes ou babás e 34\% programavam horários diferentes de trabalho com os cônjuges ou parentes. O recurso mais comum utilizado pelas mães era o horário flexível de trabalho, que vem demonstrando ser capaz de diminuir o absenteísmo e o atraso no emprego.

Bucher (1999) argumenta que os pais, ao saírem em busca de trabalho para obter melhores condições financeiras e melhor qualidade de vida, correm o risco de prejudicar o bem-estar emocional e afetivo de seus filhos, visto que as figuras parentais distanciam-se fisicamente dos mesmos e a ausência de ambos resulta na delegação de suas funções a outras instâncias, como a escola, a televisão ou a rua. Algumas pesquisas mostraram a influência negativa dos valores morais transmitidos pela televisão. Esta, além de transmitir valores negativos, inibe relacionamentos familiares nos horários em que a família se reúne para as refeições (GOMIDE, 2002).

Vale destacar que a rede de apoio tradicionalmente utilizada por mulheres, composta por avós, irmãs, primas e cunhadas, gradativamente vem deixando de estar disponível, pois essas mulheres, que antigamente ajudavam a cuidar das crianças, também saíram em busca de trabalho remunerado para aumentar a renda familiar (BREWSTER; PADAVIC, 2002). Segundo os autores, quanto maior a renda da mulher menor é o apoio da rede de parentes. Outra variável que influencia a presença ou não da rede familiar de apoio é o estado civil da mãe: se casada, menor apoio; se solteira, maior apoio da rede familiar.

Diante de uma realidade, em que não mais é possível estar em tempo integral dedicando-se ao cuidado e educação dos filhos, geram-se fontes de preocupação para estas mulheres; tendo em vista o contexto social em que vivem, minado de exemplos desviantes. 
A minha preocupação maior com eles é de eles ficar no meio de certos ambientes que eu sei que lá tem droga, né, vende droga e chega um camburão, chega a polícia, quem tiver lá vai embora. (S1)

Me preocupo com o ambiente que eles (filhos) estão, porque os irmãos do meu marido mexem com droga, fumam maconha. Quando eu conheci meu marido ele tinha levado tiro de um policial, ele usava droga. A mãe deles apoiava muito, dizia que preferia dar o dinheiro pra eles do que eles roubarem. Eles bebem muito e usam maconha.(S4)

Eu não falo com minha irmã porque ela mexe com droga. Eu saí de casa e ela ficou com meus trem, vendeu. Eu cortei as relações com ela por tudo e também porque ela tava fumando droga perto do meu filho.(S6)

Os pais espancam as mães diante dos filhos, é aquela coisa de traição, aquilo tudo vai entrando na memória da criança, elas vão crescendo com aquilo.(S7)

A idéia de proteção materna se faz presente quando se envolvem com preocupações de não exporem seus filhos a certas realidades que the parecem nocivas a sua formação tais como o consumo abusivo de álcool, drogas e violência na família. A visibilidade adquirida sobre os riscos ao desenvolvimento da criança parece ganhar relevância para estas mulheres em função de suas próprias experiências de vida.

Sabemos que no grupo de mulheres entrevistadas, a maioria é agente de violência contra os filhos, entretanto é possível identificar, em suas falas, o reconhecimento de que existam outras formas de relação entre mãe e filho.

...eu sou mãe, pai e amiga dos meus filho. Peço pros meus filho, tudo que tem pra discutir eu quero que eles falam comigo, não com os outros. Eu explico como é que é. (S10)

Eu falo pros meus filho: vai estudar, pra ter um serviço bão pra trabalhar, pra não passar o que eu passei na minha vida, porque foi muito difícil(...) Pra educar um filho não é igual eu fui criada, não precisa bater, eu não fui educada, eu fui espancada, então não precisa bater.

O mais importante na relação pais e filhos eu acho que é o amor, né. Dar mais amor pros filho, os filho também, dar mais amor pros pai, porque depois que a gente perde eles a gente fala que poderia ter amado mais. Ou, se não demonstrar o amor, às vezes a gente tem vergonha de demonstrar o amor que a gente sente e depois 
que a gente perde a gente fica pensando que podia ter falado mais, abraçado mais, beijado mais. (S3)

Assim, para elas a melhor forma de educar o filho não é com a punição ou o castigo, mas com diálogo e afeto, contrariando a realidade cotidiana em que vivem.

A compreensão que elas apresentam de educação se refere à transmissão de valores sociais que servirão de base à formação da identidade dos filhos. Podemos identificar diferenças no processo de socialização dos filhos, na dependência de ser menina ou menino, mais novo ou mais velho.

\footnotetext{
Eu preocupo com os pequenos de deixar sem as coisas. Eu luto pra não deixar eles sem o que comer, pelo menos o básico. Agora os grandes (filhos mais velhos) é essa droga que preocupa. (S7)

Tem que explicar a realidade da vida, principalmente pra filha mulher... Tem que já rasgar o verbo, como que é a vida. Os menino também já tem que falar a parte de doença e respeitar, dar educação, que é o principal disso. (S1)
}

A mãe é a primeira referência da criança em seu contato com o mundo que a cerca, o que numa primeira instância é a família. A ação de estruturas sociais como a família, com seus valores e crenças, incidindo sobre o comportamento de crianças, desde a primeira infância, leva, por meio de estratégias sutis e refinadas, a um aprendizado quase natural, ou seja, à incorporação dos habitus primários. A noção de habitus vem sendo usada para referir-se a esse aprendizado, que ocorre desde os primeiros momentos de vida e talvez até antes do nascimento (BOURDIEU, 1994).

Tanto no convívio familiar quanto nas creches e pré-escolas, entre aprovações, censuras, lições de moral, elogios, prêmios e outras modalidades de influências, as crianças vão construindo seus gostos mais íntimos, seus trejeitos, suas aspirações, sua autoimagem, sua autoestima, seus estigmas e preconceitos, enfim, vão incorporando os habitus primários que estarão no princípio das experiências escolares. São, portanto, as disposições adquiridas pela experiência de cada agente social ao longo de sua trajetória de vida, que servem de base para suas próprias 
percepções, apreciações e ações, incluindo aquelas referentes a gênero, credo, raça, classe social, orientação sexual, entre outras (BOURDIEU, 1994).

"A inscrição dos gêneros - feminino e masculino - nos corpos é feita, sempre, no contexto de uma determinada cultura e, portanto, com marcas dessa cultura" (LOURO, 2001, p.11). Nesse sentido, cabe enfatizar que a perpetuação da ordem dos gêneros esteve, até bem pouco tempo, garantida fundamentalmente pela ação conjunta de instituições como a família, a igreja, a escola e o Estado, sobre estruturas inconscientes (BOURDIEU, 1999).

Todavia, é a família que tem o papel mais relevante na reprodução da dominação masculina, pois é no ambiente familiar que a criança, desde a mais tenra idade, vai interiorizando a divisão sexual do trabalho e, consequentemente, os estereótipos vão sendo inculcados sob a forma de habitus primários. A Igreja contribui apregoando uma moral antifeminista, fundamentada em valores patriarcais, mas, principalmente, por meio da crença na inata inferioridade feminina. A escola, mesmo libertada da influência da Igreja, colabora com a reprodução de estereótipos ao fundamentar-se na representação patriarcal, que mantém uma estrutura hierárquica com forte conotação sexuada, fazendo do homem o princípio ativo e, da mulher, o passivo (BOURDIEU, 1999).

Sobre o gênero, o autor considera que não está querendo negar a biologia, mas, sim, destacar o aspecto sociocultural de sua construção. Dessa forma,

as aparências biológicas e os efeitos, bem reais, que um longo trabalho coletivo de socialização do biológico e de biologização do social produziu nos corpos e nas mentes conjugam-se para inverter a relação entre as causas e os efeitos e fazer ver uma construção social naturalizada (os 'gêneros' como habitus sexuados), como o fundamento in natura da arbitrária divisão que está no princípio não só da realidade como também da representação da realidade e que se impõe por vezes à própria pesquisa (BOURDIEU, 1999, p.9-10). 
Essa estrutura social naturalizada induz a uma enormidade de ações e decisões inquestionáveis. Assim, cabe à mulher o cuidado dos filhos, do marido, e todas as atividades por vezes invisíveis realizadas no âmbito privado, já ao homem são atribuídas aquelas tarefas perigosas ou espetaculares do espaço público (BOURDIEU, 2002).

É nesse processo de socialização dos filhos que surgem conflitos, em que, nem sempre a negociação se resolve no diálogo entre mãe e filho, ocorrendo, então, atos de violência recíproca. A condição econômica desfavorável também se constitui como um fator de conflito no relacionamento, manifestando comportamentos de rebeldia por parte do filho frente à recusa materna.

Às vezes, meu relacionamento com meu filho é bom, às vezes é ruim. Ele é muito desobediente, ele quer as coisas que eu não posso dar. (S6)

\begin{abstract}
Meu relacionamento com meus filhos é meio cruel, porque eu vou dar conselho, eles não me obedece, me xingam, gritam comigo; uns tempo pra trás aí até me batia. 0 de 16 anos me batia... o de 16 anos, que é muito rebelde (...), ele fala de agressão, aí eu rodo a baiana. E eu falo 'Põe a mão em mim pra você ver'. Aí um colega meu que é do babado carcou o fumo nele, explicando que em mãe não se bate, que se ele por a mão em mim a próxima vez ele vai apanhar, só deu o recado... Quando deu a hora eu vou lá e falo que já to fechando a porta, eu encosto e quando deu a hora, eles ficam mais um pouquinho e depois já entram pra dentro, porque aí eu já começo a falar meio grosso.(S1)
\end{abstract}

Na relação conflitiva mãe e filho, as ameaças são mútuas. Em uma revisão sobre as evidências relativas às influências adversas do cuidado materno inadequado durante a primeira infância no desenvolvimento da personalidade, Bowlby (1988) aponta estudos que apresentaram correlações consistentes entre a carência de um vínculo afetuoso saudável na infância e a delinquência juvenil.

Ainda é importante destacar o termo "falar meio grosso", tal como referido pela entrevistada $\mathrm{S1}$, que guarda a idéia de resgatar a autoridade sobre os filhos sob a égide da tradicional autoridade masculina, de chefe de família. 
A este respeito Sarti (2003) observa que a autoridade moral é ainda reiterada na figura masculina. O lugar masculino identifica o homem como mediador entre a família e o mundo externo. Essa autoridade fundamenta-se na complementaridade hierárquica entre homem e mulher, que não necessariamente são figuras parentais. O homem ainda é considerado chefe da família e a mulher chefe da casa. A essa divisão complementar, em que coexistem diferentes funções da autoridade na família, somam-se conceitos de moral e respeito ainda corporificados na figura masculina.

Nurco e Lerner (1996) encontraram uma forte influência da figura paterna na inibição de comportamentos antissociais e de uso de drogas. Os autores verificaram que em famílias cujos pais eram presentes e forneciam modelos morais adequados, criando condições para que seus filhos exercitassem vários tipos de comportamentos morais - como honestidade, generosidade, justiça - não foram encontrados filhos usuários de drogas e com comportamentos antissociais. O mesmo efeito não foi encontrado quando as mães apresentavam esses atributos. Aparentemente a mulher assumiu as funções de cuidadora e provedora, porém ainda não adquiriu o status de referencial moral para a sociedade.

Atos de autoritarismo das mães utilizando a punição como medidas educativo-disciplinares são também referenciados por elas, o que comparam como de longe ser semelhante ao que foram submetidas quando crianças.

Conversar demais, eu também não tenho muita paciência não. Conversar demais cansa. Por de castigo também não adianta. Tem que bater, um pouco ele faz pra chamar atenção. Sabe que tá errado. Aí eu pego o chinelo, mas eles fica sem vergonha. Minha mãe não esperava nem chegar em casa, já apanhava no meio da rua. (S8)

Eu faço com meu filho o que ninguém fez pra mim, mas, às vezes, ele é muito arteiro e eu bato nele sim, porque eu falo pra ele e ele fingi que não escuta. Mas em vista do que eu fui tratada eu trato ele muito bem. (S6)

Eu não sei bater de cinta, tenho medo de deixar sinal. A menina pegou trauma porque já apanhou de coleira de cachorro. O Junior também acho que já apanhou de cinta, por que a gente pega 
trauma.(...) Ela tem urina solta, to levando na psicóloga. Eu não sei se é por causa do pai, mas ele não quer nem saber. Eu acho que foi por causa das agressões do pai. Ela não tinha esse problema, ta tendo agora depois que voltou de lá. A psicóloga disse que é da cabeça, que vai voltar, que demora.(S8)

Eu dava castigo, tirava a roupa deles, deixava pelado e eles não saíam pra rua.(S2)

Dentro dessa ótica, a criança deve sempre aprender a obedecer, "sendo que a autoridade do adulto sobre ela assume, muitas vezes, uma configuração autoritária, possibilitando situações de exercício de poder. Em nome da disciplina e da obediência, a criança é maltratada" (MARMO; DAVOLI; OGIDO, 1995, p. 314).

Alguns pesquisadores relatam que, embora a punição corporal possa ser eficaz no instante em que é aplicada, em longo prazo pode acarretar prejuízos não somente para o indivíduo que a recebe, mas também para os outros com quem convive, aumentando os índices de delinquência, criminalidade e violência contra o cônjuge (WEBER; VIEZZER; BRANDENBURG, 2004).

Outros autores concordam que a punição apenas enfoca o erro e não há preocupação em ensinar aquilo que é correto. No entanto, alguns estudos defendem o uso de tais atos, devido ao benefício imediato alcançado, pois os pais conseguem pronta obediência da criança (WEBER; VIEZZER; BRANDENBURG, 2004).

Diferentes pesquisas elaboradas com o objetivo de relacionar o recebimento da punição corporal com alguma variável comportamental da criança encontraram prejuízos para o desenvolvimento infantil: as crianças que apanhavam - comparadas com as que não apanhavam apresentavam autoestima mais baixa, comportamento mais agressivo, maior frequência de sintomas psiquiátricos e menor bem-estar geral (WEBER; VIEZZER; BRANDENBURG, 2004).

Estudos comparativos de métodos disciplinares que se utilizam de punição corporal evidenciaram que o efeito positivo imediato pode ser alcançado igualmente por uma punição não-física, chegando à conclusão 
de que os dois métodos são igualmente eficazes (WEBER; VIEZZER; BRANDENBURG, 2004).

A problemática da violência familiar contra a criança e o adolescente é um fator comum à fala de todas as mulheres/mães que integram o grupo de sujeitos deste estudo. Dentre as formas de relação mãe e filho que se caracteriza como violência, não necessariamente são percebidas pelas mulheres deste estudo como ato de violência, o que inclui a violência física, psicológica e a negligência.

Oh, quando meus filho apanha é porque mereceu, bateu, levou. Eles fala que vai na praça ou na igreja e tem que chegar na hora certa. (S2)

Eu perdi a guarda dele, porque morava tudo junto, numa casa, uma família meio bagunçada. Minha irmã saía largava as crianças comigo, eu saia e largava as crianças sozinhas. Aí o Conselho ia, pegava. Quando ele era pequeno eu não batia de machucar, de deixar sinal, batia só pra corrigir mesmo, dava chinelada, tapa. (S8)

Diante desta realidade o que se apresenta é uma situação paradoxal por ferir a visão idealizada de boa mãe. Observam Barbosai e Pergoraro (2008) que é comum associar atos de violência ao homem como sendo uma situação um tanto complicada, quando em verdade a agressora é a mãe, pois no imaginário social tem-se a mãe como ser generoso, doce, incapaz de qualquer mal, principalmente a sua prole. Acrescentam as autoras que na relação mãe e filho o que se estabelece é uma relação de amor incondicional, na qual estão presentes apenas sentimentos positivos. Entretanto no cotidiano destas relações as mulheres tendem a assumir uma carga pesada de responsabilidades e cobrança social, sendo, muitas vezes, a autoridade materna confundida com autoritarismo, em que o uso da violência aparece como única solução para resolver conflitos.

$\mathrm{Na}$ busca de compreender o que leva essas mães a agredirem seus filhos, a literatura científica tem apresentado diferentes formas de explicação para a violência intrafamiliar contra a criança/adolescente, o que é resumido por uma modelo explicativo apresentado por Gomes et al. 
(2002). No modelo Reprodutivo ou de Aprendizagem Social há a reprodução de experiências de violência familiar vividas durante a infância, contribuindo para que se perpetuem os maus-tratos; no Psicodinâmico, a violência é entendida como produto de desajustes familiares, psíquicos e do alcoolismo e, assim, a explicação para a situação de violência costuma ser ancorada numa análise psicológica da personalidade dos agressores; o modelo Sociológico, por sua vez, abrange a ordem macroestrutural por trás da ocorrência dos maus-tratos, isto é, compreende aspectos sociais, econômicos e culturais; o Sociopsicológico articula em rede as diversas ordens explicativas, integrando a questão macroestrutural com os aspectos psicológicos; e, por fim, o modelo Ecológico considera a origem de todas as formas de abuso contra crianças/adolescentes um processo interativo complexo, como resultante de múltiplos fatores em interação, produzindo as circunstâncias oportunas para o surgimento da agressão.

Em relação aos aspectos discutidos pelos autores acima, podemos identificar, no grupo de mulheres estudadas, a presença de uma conjunção de fatores pessoais e familiares que favorecem as disfunções no vinculo mãe e filho.

Além da permanência de condições familiares sociais e econômicas desfavoráveis, como já enfatizado nas categorias anteriores, é possível identificar desajustes no âmbito pessoal, tais como serem em sua maioria usuárias de álcool, consumo esse iniciado em idades precoce, seguindo exemplos na própria família.

... com 12 anos, eu acredito que foi quando eu comecei com o problema de alcoolismo. A gente ia almoçar, tinha um barzinho de frente e aí todo dia, na hora do almoço ela (mãe) ia lá tomar um aperitivo, e eu via aquilo e me acostumei a fazer o mesmo, eu fazia escondido. Aí eu comecei a beber, beber e beber, chegava em casa bêbada. Eu acostumei a tomar conhaque, eu era jovem, os conhecidos pagavam, foi quando eu comecei a beber. Eu comecei a ficar alcoolizada com 15, 16 anos. (S4)

O consumo de drogas ilícitas por adolescentes, como a maconha e a cocaína, é relativamente baixo quando comparado ao uso das drogas 
lícitas, como o álcool e o tabaco (GALDURÓZ; NOTO; CARLINI, 1997). Ao contrário das drogas ilícitas, o primeiro contato que a maioria dos adolescentes tem com o álcool ocorre dentro de casa, sob o olhar complacente da família, que aceita e tolera esse tipo de substância.

Vale considerar que o consumo de álcool é visto de forma diferenciada nas sociedades. Alguns estudos apontam que o consumo de álcool e outras drogas estão presentes nos processos de socialização, em várias culturas, marcando a passagem do jovem para a vida adulta masculina. Segundo Nascimento (1999), essa passagem ocorre cada vez mais cedo: $50 \%$ da população masculina, entre 10 e 12 anos, já fizeram uso do álcool. Porém, o uso de álcool e drogas também está crescendo consideravelmente entre as mulheres.

De maneira geral, as mulheres consomem álcool de forma menos frequente que os homens. Apesar da menor pressão social para iniciar o consumo do álcool, em detrimento da maior pressão para parar o uso, o julgamento social em relação à mulher usuária de álcool continua sendo muito árduo (BLUME, 1990).

Estudo desenvolvido por Cesar (2006) parte do princípio que seja importante investigar as especificidades do alcoolismo feminino considerando questões pertinentes à mulher no espaço social. Neste sentido, analisa o alcoolismo sob o aspecto do gênero em que, vinculado ao sexo masculino, seria basicamente de natureza social, e que a ausência de mulheres nessa categoria poderia estar vinculada a uma dupla moral implícita na prática do consumo de álcool. Essa dupla moral não só não favoreceria o consumo entre mulheres, como aumentaria o estigma para com as mulheres que bebem, impondo ao sexo feminino padrões mais rígidos.

Não só o alcoolismo pode ser considerado como fator pessoal de desajustes nas relações interpessoais, tais como apresentado neste estudo entre mães e filhos. Chamamos atenção para as experiências vivenciada por estas mulheres na infância, ou seja, de um passado 
marcado por violência e hoje reencenam tais situações assumindo posições que as colocam como agentes na situação de violência.

As marcas deixadas pela violência não são somente físicas, mas sequelas emocionais, podendo prejudicar o aprendizado, as relações sociais e o desenvolvimento pleno, exercendo impacto a longo prazo, com repercussões na família e na sociedade (SANCHEZ; MINAYO, 2006).

O indivíduo que sofreu maus tratos na infância ou não foi uma criança aceita, reconhecida ou desejada terá consequências que se refletirão no futuro, particularmente na forma como irá tratar seus filhos (BRINGIOTTI, 2005). Entretanto, refere a autora que isso não acontece de forma determinista, geralmente há recursos e fatores de proteção que medeiam os efeitos em cada caso.

Dessa forma, o que se pode evidenciar como comum a essas mulheres é o ciclo vicioso da violência. Diante desta constatação é importante relativizar o fato de que as mães agridam seus filhos porque foram agredidas na infância. Entretanto, apreende-se a ciclicidade da violência na descrição dos eventos cotidianos, em que os filhos, agora adultos, reproduzem a mesma atitude violenta dos pais.

\footnotetext{
Ela (a filha) xinga eu (a mãe) de puta, de biscate, vagabunda. Eu até saio. Esses dias eu (a mãe) bati nela, bati na cara dela, mês passado. Ela puxou meu cabelo e eu fui pra cima dela e bati nela. O cara que ela largou mexia com droga. Ela bate nos filhos, nas costas, na cabeça, bate com a mão, com o chinelo, com tudo. As costas do moleque fica até vermelha. Ela fala palavrão na frente dos filhos, ela não respeita (S2).
}

Em relação à violência contra a criança e o adolescente, Algeri e Souza (2006) acreditam que há um ciclo geracional de violência, ou seja, uma vez constantemente submetidos à violência aprendem que só através de tal forma há resolução de conflitos. 


\section{A compreensão da dissociação do papel materno que se expressa em violência contra a criança/ adolescente}

As representações que significam e inscrevem a maternidade no corpo e na alma das mulheres de serem afetivas continentes e dóceis, nos colocam frente a uma visão incompreensível da violência que mães cometem contra seus filhos. Neste sentido, um importante passo para responder construtivamente diante de uma situação de violência contra a criança ou adolescente é nos desvestirmos dos estigmas em relação às mães agressoras e buscar compreendê-las em suas trajetórias de vida, as quais as conformaram e conformam como mães, revelando características de indeterminação, ambiguidade e instabilidade frente a seus papéis sociais, entre eles o materno.

Partimos de uma realidade comum a todas as mulheres do estudo, serem elas mães de crianças em situação atual ou anterior de violência intrafamiliar, seguidas pela justiça da Comarca de Jardinópolis/SP e participantes do projeto "Intervenções breves para pessoas que abusam de álcool e drogas".

Tivemos como pressuposto que os significados que as mulheres atribuem à maternidade e as formas de atuarem no cuidado com os filhos guardam relação com processos de socialização aos quais foram submetidas junto às suas mães e famílias, revelando possivelmente uma cíclica violência familiar que, na maioria das vezes, se mostra naturalizada e inevitável. Além disso, a dissociação do papel materno que se expressa em violência contra a criança está ligada a vários fatores isolados ou em conjunção, como sua condição social e relacional além do consumo de álcool e drogas ilícitas.

$\mathrm{Na}$ busca de responder a este pressuposto buscamos nos aproximar das vivências destas mulheres no contexto da família de origem 
e da família atual, no sentido de identificar fatores que guardassem relação com a violência que manifestam contra seus filhos.

A análise da violência contra a criança e o adolescente manifestada pelas mães deste estudo aponta para um perfil comum de mães agressoras: durante a infância e adolescência na família de origem conviveram com perdas, situações de alcoolismo e violência, afetos e desafetos, situações estas que se refletem no contexto familiar atual, no qual se observa certa ciclicidade de desestruturação familiar, em que, nas diversas etapas da vida, as mulheres estudadas assumem diferentes posições de sujeito dentro do contexto da violência intrafamiliar.

Podemos dizer que tais pressupostos por nós propostos foram comprovados através das categorias temáticas configuradas pelos núcleos de sentido presentes nas falas desses atores.

No contexto da trajetória de vida das mulheres durante a convivência com suas famílias de origem, as três categorias temáticas Convivendo com as perdas: “... eu fiquei pro mundo"; Convivendo com alcoolismo, pobreza e violência em família; Convivendo com afetos e desafetos: "eu achava tão bom, tão gostoso quando ela me chamava de filha, era muito raro, muito raro" - retratam suas vivências quando criança e adolescentes, ou seja, convivendo com perdas de entes queridos, situações de alcoolismo e violência, afetos e desafetos, as quais contribuem para a desestruturação da família.

O fato de a violência ocorrer dentro da família denuncia a falta de estruturação familiar, que poderia ser o referencial para o desenvolvimento psicológico e social de seus membros. Sendo assim, podemos dizer que a violência intrafamiliar rompe o vínculo de confiança básica para o desenvolvimento da vida em família.

Fazendo uma análise da família atual, observamos uma repetição das trajetórias de vida dessas mulheres, descrita pelas categorias: “Eu tentei construir uma família... bem ou mal ela tá aí"; "Minha vida da infância ao casamento parece que foi igual ( ...) continuei sendo 


\section{agredida" e; "Eu bato nele $\operatorname{sim}(. .$.$) , mas em vista do que eu fui$ tratada, eu trato ele muito bem".}

Diante desta constatação é que concordamos com Bringiotti (2005) que, com base nos trabalhos de Tornaría, Vandemeulebroecke e Colpin (2001) e Belsky (1993), acredita ser necessário considerar, frente à situação de violência infantil, as características de famílias de risco para maus tratos na infância. Assim, apresenta um modelo teórico com um conjunto de variáveis, que incluem conhecer: as características e histórias pessoais de cada um dos pais, as experiências da infância de apoio e afeição, adequados modelos parentais, presença de figuras de apego e também as características da criança (desejado, aceito, com problemas de doença ou deficiência), as relações familiares, principalmente a conjugal, as relações com as crianças, as condições sociais e econômicas de trabalho, de habitação, a presença ou ausência de redes de apoio social e os laços locais e, culturalmente, os papéis a serem desempenhados por homens e mulheres, a tolerância do castigo na educação e a própria concepção de crianças.

Importante expormos que, na família, a mãe historicamente é tida como elemento de sustentação da esfera familiar e é através dela que a criança estabelece inicialmente o contato com seu mundo exterior e vai assumindo e interiorizando, mediante a linguagem, determinados papéis e modelos relacionais. Entretanto, dificuldades interpessoais podem se apresentar e comprometer a qualidade do relacionamento entre mãe e filho. Em nosso estudo percebemos a dissociação do papel materno que se estabelece por fatores isolados ou em conjunção, advindos de experiências anteriores na família de origem e por condições sociais, econômicas e culturais da família atual. As relações conflituosas entre mães e filhos manifestam-se em comportamentos de agressividade, negligência, os quais podem justificar medidas mais drásticas como a institucionalização de crianças e adolescentes.

Entre as mulheres estudadas, em que pese às experiências anteriores e a condição contextual familiar atual na forma como se 
relacionam com seus filhos, buscamos identificar como Ihes significa 0 papel de ser mãe. Neste sentido, deixam evidenciar certo valor de proteção maternal, quando se atêm a realidade de vulnerabilidade em que seus filhos estão expostos no contexto relacional familiar e extra-familiar. Naturalizam as surras como estratégias para educar os filhos, embora reconheçam a existência de outras formas de se lidar com a criança ou adolescente.

No contexto atual, as formas de castigos e surras não mais fazem parte do repertório de estratégias para disciplinar os filhos. A este respeito, Souza (1997) refere que a família atual encontra-se oscilante, pois ora utiliza os pressupostos hierarquizados, ora assume o modelo igualitário. Em geral a coexistência destes modelos invariavelmente vem firmando uma inconsistente e ineficaz funcionalidade educacional quanto ao estabelecimento de limites às crianças. A ambiguidade suscitada pela pré-existência de relações familiares verticais e horizontais excessivamente opostas parece ter-se radicalizado no tocante ao enfraquecimento da figura de autoridade na sociedade contemporânea.

Observa-se o surgimento e a manutenção da inversão de papéis, o que torna provável que os filhos, desde a infância, desconheçam a frustração estruturante que deveria ser exercida pelas figuras parentais. As transformações sócio-históricas afetaram consideravelmente a dinâmica e a funcionalidade familiar. A autora acima afirma que a família contemporânea parece se desencontrar, sob a sombra da indefinição do modelo arcaico hierarquizado ou sob o excesso de permissividade do modelo igualitário.

As figuras parentais, temendo reproduzir os erros da própria educação e na ânsia de se adequar ao rótulo de "modernas", recorrem aos pressupostos científicos psicopedagógicos (WAGNER, 2003). Soma-se a isso a sobrecarga de trabalho e estresse provenientes do exercício profissional diário dos pais ou de quem exerça esse papel. A conquista da mulher frente ao mercado de trabalho não a eximiu das antigas atribuições sociais no tocante à educação dos filhos e às tarefas 
domésticas. Para a autora, os pais sentem-se em dívida em relação às demandas afetivas de seus filhos e tendem a compensar o sentimento de culpa recorrendo a uma permissividade excessiva. Assim, ao se basearem na parentalidade igualitária, lançam mão de técnicas disciplinares ineficazes quanto ao estabelecimento de limites junto aos filhos.

Autores como Oliveira e Caldana (2004) argumentam que, como consequência dessa mudança, podem-se observar alterações das práticas e valores que sustentam a educação da criança na família neste século. Essas mudanças estão pautadas em um enfoque antiautoritário e uma maior preocupação com a felicidade da criança, com seu bem-estar emocional e uma maior importância às questões afetivas.

Tal transformação de valores sobre a educação foi mencionada pelas mulheres referindo-se ao passado em que se aceitavam socialmente formas punitivas aos filhos em nome da disciplina que hoje são caracterizadas como forma de violência. Entretanto, frente a seus atos agressivos, as mulheres parecem negar a existência de violência, tendo em vista que esta foi a forma em que foram disciplinadas por seus pais ou responsáveis e que agora se utilizam de forma abrandada junto a seus filhos, tal como podemos depreender da fala: "Eu bato nele sim (...), mas em vista do que eu fui tratada, eu trato ele muito bem".

A violência física, cujo impacto parece ser temporário e desaparecer no decorrer do desenvolvimento infantil, é muitas vezes subestimada. A agressão contra a criança/adolescente deve ser reconhecida como um sério problema. Mesmo que crianças vitimizadas sejam retiradas de suas casas, os efeitos da experiência vivida repercutirão por toda vida (DAY et. al., 2003).

Diante destes resultados, é importante que se elaborem estratégias que ajudem aos pais sensibilizar-se quanto ao fato de as agressões físicas deixarem marcas negativas em longo prazo, partindo de suas próprias vivências na infância. Ao mesmo tempo em que os ajude a criar habilidade para se utilizar de práticas educativas sem punição corporal, tal como o diálogo. Este, além de ajudar no desenvolvimento de 
habilidades sociais dos filhos, mantém uma dinâmica familiar com responsividade, afeto e comprometimento (WEBER; VIEZZER; BRANDENBURG, 2004).

Nossos achados reiteram ser a violência contra crianças e adolescentes um abuso do poder disciplinador e coercivo dos pais e/ou responsáveis, em que a vítima é completamente objetificada e seus direitos fundamentais como a vida, a liberdade e a segurança desrespeitados. Essa subordinação de crianças e adolescente a diversas formas de maus-tratos no ambiente familiar pode ter duração indefinida devido à sacralidade desta instituição e à autoridade que os pais exercem sobre os filhos, impondo-lhes um pacto de silêncio e, por vezes, cumplicidade.

Podemos dizer que a violência se estrutura em padrões culturalmente introjetados e manifesta-se contínua e veladamente. A magnitude do problema da violência na atualidade vem ganhando destaque devido à repercussão dos seus prejuízos na sociedade. Devemos enfatizar que a violência intrafamiliar não pode deixar de ser reconhecida e entendida como um fenômeno articulado à violência estrutural e social a que os sujeitos, suas famílias e sociedade em que vivem estão expostos, sendo também uma questão de ordem política.

De modo geral, as políticas públicas e específicas de atenção e prevenção à violência, dirigidas à criança e ao adolescente, enfatizam o importante papel da inserção do tema no âmbito do ensino nos diversos níveis, devido à magnitude e impacto na saúde da população brasileira. Às políticas agregam-se leis como os Estatutos da Criança e do Adolescente, que destaca que a violência precisa ser enfrentada. Uma forma de fazê-lo é sensibilizar, capacitar e formar pessoas dos mais diversos âmbitos da sociedade, mas, sobretudo, os alunos e profissionais do setor saúde, em especial da enfermagem, para onde convergem as vítimas desses eventos.

Reconhecendo que o objetivo maior do conhecimento científico é a fundamentação para a orientação de ações humanas transformadoras 
do cotidiano, acreditamos que este estudo possa ter contribuído para ampliar e fundamentar a intervenção de enfermagem efetiva e transformadora.

Reforçamos que o enfoque dessa intervenção, tanto da enfermagem quanto de todos os profissionais da saúde nessa problemática, deve basear-se no fortalecimento das respostas das famílias das vítimas de violência intrafamiliar, pois esse é um método eficiente para reduzir traumas nas vítimas e evitar a ciclicidade da violência, que foi constatada neste estudo.

Acreditamos ser importante a implementação de práticas junto aos agressores, os quais requerem atenção assim como as vítimas, contribuindo para o fortalecimento do núcleo familiar, ajudando-os a encontrar soluções efetivas para recuperarem sua dignidade e respeitabilidade recíproca. 


\section{REFERÊNCI AS ${ }^{1}$}

ADORNO, R. C. F. Uso de álcool e drogas, contextos sociais e contextos de violências. SMAD. Revista Eletrônica Saúde Mental Álcool e Drogas, v. 4, p. 2-10, 2008.

ALATORRE, J.; LUNA, R. Significados y prácticas de la paternidad en la ciudad de México. FULLER, N. (Org.). Paternidades en América Latina, p.241-275, 2000. Lima: Fondo Editorial PUCP.

ALEXANDRE, D. T.; VIEIRA, M. L. Relação de apego entre crianças institucionalizadas que vivem em situação de abrigo. Psicologia em Estudo, Paraná, v.9, n. 2, p.207-17, 2004.

ALGERI, S.; SOUZA, L. M. Violência contra crianças e adolescentes: um desafio no cotidiano da equipe de enfermagem. Rev. Latino-Am. Enf., Ribeirão Preto, v.14. n.4. p. 625-31, 2006.

ALMEIDA, J. A. G. de. Amamentação: um híbrido natureza-cultura. Rio de Janeiro: Fiocruz, 1999.

ALVES, J. C. M. Direito Romano. Rio de Janeiro: Forense, v.2, n. 282, 1977.

ARAÚjO, M. F. Violência e abuso sexual na família. Psicol. Estud., Paraná, v.7, n.2, 2002.

ARIĖS, P. História social da criança e da família. Rio de Janeiro: Guanabara, 2. ed., 1986.

ÁRIES, P.; DUBY, G. História da vida privada I. Porto, Portugal: Afrontamento, 1990.

ASSIS, S. G. Crianças e adolescentes violentados: passado, presente e perspectivas para o futuro. Caderno de Saúde Pública, v.10, p.126-34, 1994.

\footnotetext{
${ }^{1}$ De acordo com a Associação Brasileira de Normas Técnicas. NBR 6023.
} 
ASSIS, S. G.; AVANCI, J. Q.; SANTOS, N. C.; MALAQUIAS, J. V.; OLIVEIRA, R. V. C. Violência e representação social na adolescência no Brasil. Rev. Panam. Salud. Publica, Washington, v.16, n.1, p.43-51, 2004.

ASSOCIAÇÃO BRASILEIRA DE PROTEÇÃO À INFÂNCIA E ADOLESCÊNCIA ABRAPIA. Maus-Tratos contra Crianças e Adolescentes: proteção e prevenção. Guia de Orientação para Profissionais de Saúde. Rio de Janeiro: ABRAPIA, 1992.

AZEVEDO, G. R. de. Cuida-dor (d)eficiente: as representações sociais de familiares do processo de cuidar. 2001. 106p. Dissertação (Mestrado)Escola de Enfermagem de Ribeirão Preto, Universidade de São Paulo, Ribeirão Preto, 2001.

AZEVEDO, K. R.; ARRAIS, E. R. O mito da mãe exclusiva e seu impacto na depressão pós-parto. Psicologia: Reflexão e Crítica, Porto Alegre, v.19, n.2, p.269-276, 2006.

AZEVEDO, M. A. Contribuições brasileiras à prevenção da violência doméstica contra crianças e adolescentes. In: WESTPHAL, M. F. (Org.). Violência e criança. São Paulo: Editora da Universidade de São Paulo, p.125-135, 2002.

AZEVEDO, M. A.; GUERRA, V. N. A. I nfância e violência doméstica: fronteiras do conhecimento. São Paulo: Cortez, 2000.

BADINTER, E. Um amor conquistado: o mito do amor materno. São Paulo: Círculo do Livro, 1988.

BAHR, S. J.; HOFFMANN, J. P.; YANG, X. Parental and peer influences on the risk of adolescent drug use. The Journal of Primary Prevention, v.26, n.6, p.529-551, 2005.

BAPTISTA, S. M. S. Maternidade e profissão: oportunidade de desenvolvimento. São Paulo: Casa do psicólogo, 1995.

BARBOSAI, P. Z.; PEGORARO, R. F. Violência doméstica e psicologia hospitalar: possibilidades de atuação diante da mãe que agride. Saúde soc., São Paulo, v.17, n.3, jul/set., 2008. 
BARDIN, L. Análise de conteúdo. Tradução de Luis Antônio Reto; Augusto Pinheiro. Lisboa: Edições 70, p.42, 1979.

BARNETT, O. W.; MILLER-PERRIN, C. L.; PERRIN, R. Family violence across the lifespan: an introduction. London: Sage Publications; 1997.

BAZON, M.R. Violências contra crianças e adolescentes: análise de quatro anos de notificações feitas ao Conselho Tutelar na cidade de Ribeirão preto, São Paulo, Caderno de Saúde Pública, Rio de Janeiro, v.24, n.2, p.323-32, 2008.

BELSKY, J. Etiology of child maltreatment: a developmental, ecological analysis. Psychological Bulletin, v.114, n.3, p.413-34, nov. 1993.

BEM, L. A.; WAGNER, A. Reflexões sobre a construção da parentalidade e o uso de estratégias educativas em famílias de baixo nível socioeconômico. Psicologia em Estudo, v.11, n.1, p.63-71, 2006.

BENGER, J. R.; PEARCE, V. Simple intervention to improve detection of child abuse in emergency departments. BMJ , p.324-780, 2002.

BERQUÓ, E. Perfil demográfico das chefias femininas no Brasil. In: Seminário estudos de gênero face aos dilemas da sociedade brasileira. Anais do Seminário estudos de gênero face aos dilemas da sociedade brasileira. Itu: Sociedade Brasileira da Fundação Carlos Chagas, 2001.

BERTAUX, D. L'approche biographique: sa validité méthodologique, ses potentialités in histoires de vie et vie sociale. Cah. Int. Sociol., v.27, n.69, p.197-225, 1980.

BIGNARDI, F. A. C. Reflexões sobre a pesquisa qualitativa e quantitativa: maneiras complementares de apreender a realidade. São Paulo: Comitê Paulista para a Década da Cultura de Paz - um programa da UNESCO, out., 2003.

BLACK, D. A.; SLEP, M. A. S.; HEYMAN, R. E. Risk factors for child psychological abuse. Aggress Violent Behav, v.6, p.189-201, 2001. 
BLUME, S. Women and alcohol: a review. J. Am. Med. Assoc., v.256, p.1467-70, 1990.

BOCK, A. M. B. A Psicologia Sócio-Histórica: Uma perspectiva Crítica em Psicologia. In: BOCK, A. M. B.; MARCHINA, M. G.; FURTADO, O. (Org.) Psicologia sócio-histórica: uma perspectiva crítica em psicologia. São Paulo: Cortez, p. 15-35, 2001.

BOULDING, E. Las mujeres y la violencia. In: La violencia y sus causas. Editorial UNESCO. Paris - França, p. 265-279, 1981.

BOURDIEU, P. A dominação masculina. Rio de Janeiro: Bertrand Brasil, p.9-10, 1999.

Pierre Bourdieu entrevistado por Maria Andréa Loyola. Rio de Janeiro: EdUERJ; p.50,2002.

. Trabalhos e Projetos. In: ORTIZ, R. (org.). Pierre Bourdieu: sociologia. São Paulo: Ática; p.38-45, 1994.

BOWLBY, J. Cuidados maternos e saúde mental. São Paulo: Martins Fontes, 1988.

- Separação. Da trilogia apego e perda. São Paulo: Martins Fontes, v.3, 1984.

. Uma base segura: aplicações clínicas da teoria do apego. Porto Alegre: Artes Médicas, 1989.

BOYLE, A.; ROBINSON, S.; ATKINSON, P. Domestic violence in emergency medicine patients. Emerg. Med. J., v.21, p.9-13, 2004.

BRASIL. Lei No. 8.069. Dispõe sobre o Estatuto da Criança e do Adolescente e dá outras providências. Diário Oficial da República Federativa do Brasil, 13 jul. 1990. Seção 1.

Código de menores. Lei n. 6.697. São Paulo: Editora Jalovi, 
BRASIL. Senado Federal. 5 out. 1988. Constituição da República Federativa do Brasil. Brasília: Senado Federal, 1988.

. Congresso Nacional. Lei no 11.340. Dispõe sobre a Lei Maria da Penha, ago. 2006a.

- Ministério da Saúde. Política nacional de redução da morbimortalidade por acidentes e violências. Brasília: MS, p.5-15, 2001b.

- Ministério da Justiça. Plano nacional de enfrentamento da violência sexual infanto-juvenil. Brasília: Ministério da Justiça; Secretaria de Estado dos Direitos Humanos/Departamento da Criança e Adolescente, 2001c.

- Ministério da Saúde. Plano nacional de promoção, proteção e defesa do direito de crianças e adolescentes à convivência familiar e comunitária. Brasília, 2006b.

- Ministério da Saúde. A Política do Ministério da Saúde para Atenção Integral a Usuários de Álcool e Outras Drogas / Ministério da Saúde Secretaria Executiva. Secretaria de Atenção a Saúde. C. N. DST/AIDS. - 1. ed. - Brasília: Ministério da Saúde, 2003.

- Ministério da Saúde. Notificação de maus-tratos contra crianças e adolescentes pelos profissionais de saúde: um passo a mais na cidadania em saúde. Brasília: Secretaria de Assistência a Saúde, v. $167,2002$.

- Ministério da Saúde. Secretaria de Políticas de Saúde. Violência intrafamiliar: orientações para a prática em serviço. Brasília: MS, 2001a.

- Ministério da Saúde. Secretaria de vigilância em saúde. Saúde Brasil 2007: uma análise da situação de saúde. Perfil de Mortalidade do Brasileiro, nov. 2008. Disponível em: <http://portal.saude.gov.br/portal/ arquivos/pdf/coletiva_saude_061008.pdf>. Acesso em: 06 jan. 2009.

- Ministério da Saúde. Violência contra a criança e o adolescente: proposta preliminar de prevenção e assistência à violência doméstica. Brasília: MS, 1997. 
BRASIL. Ministério do Planejamento, Orçamento e Gestão. INSTITUTO BRASILEIRO DE GEOGRAFIA E ESTATÍSTICA- IBGE. Censo Demográfico 2000: resultados do universo, 2000. Disponível em: <http://www.ibge. gov.br/home/estatistica/populacao/censo2000/default.shtm>. Acesso em: 20 ago. 2008.

- Tribunal de Contas da União. Relatório de avaliação do programa: programa de combate ao abuso e exploração sexual de crianças e adolescentes. Brasília : TCU, Secretaria de Fiscalização e Avaliação de Programas de Governo, p. 30-100, 2004.

BREWSTER, K. L.; PADAVIC, I. No more kid care? Change in Black Mother's Reliance on relatives for child care, 1977-94. Gender \& Society, v.16, n.4, p. 546-563, 2002.

BRINGIOTTI, M. I. Las familias en "situación de riesgo" en los casos de violencia familiar y maltrato infantil Texto contexto - enferm., Florianópolis, v.14, n. especial, 2005.

BRITO, A. M. M.; ZANETTA, D. M. T.; MENDONÇA, R. de C. V.; BARISON, S. Z. P.; ANDRADE, V. A. G. Domestic violence against children and adolescents: a supporting program study. Ciênc. saúde coletiva. Rio de Janeiro, jan./mar., v.10, n.1, 2005.

BRITO-DIAS, C. M. S. A importância dos avós no contexto familiar. Psicologia: teoria e pesquisa, v.10, p.31-40, 1994.

BRUNDENELL, I. A grounded theory of protecting recovery during transition to motherhood. American J ournal Drug Alcohol Abuse, v.23. n.3, p.453-66, 1997.

BUCHER, J. S. N. F. O casal e a família sob novas formas de interação. In: FÉRES-CARNEIRO, T. (Org). Casal e família: entre a tradição e a transformação. Rio de Janeiro: NAU, p.82-95, 1999.

CABRAL, I. E.; TYRRELL, M. A. R. O estilo de cuidar da mãe e o trabalho da enfermagem. Rev. Enfermagem UERJ, Rio de Janeiro, v. 3, n. 2, p.189-195, out., 1995.

CAMARGO, C. L.; BURALLI, K. O. Violência familiar contra crianças e adolescentes. Salvador: Ultragraph, 1998. 
CASTRO NETO, A. A criança maltratada. Pediatria Moderna, São Paulo, v.30, n.2, p.49-27, 1994.

CASTRO, M. G.; ABRAMOVAY, M. Jovens em situação de pobreza, vulnerabilidades sociais e violências. Cadernos de pesquisa, São Paulo, v. 116, p. 143-76, 2002.

CAVALCANTE, F. G.; GOLDSON, E. Avanços na implementação de políticas e ações no campo da deficiência e saúde mental. Ciência e saúde coletiva, Rio de Janeiro, v. 14, n.1, 2009.

CÉSAR, B. A. L. O Beber Feminino: a marca social do gênero feminino no alcoolismo em mulheres. 2005. 130f. Dissertação (Mestrado em Saúde Pública) - Escola Nacional de Saúde Pública Sérgio Arouca, Fundação Oswaldo Cruz, Rio de Janeiro, 2005.

Alcoolismo feminino: um estudo de suas peculiaridades. Resultàdos preliminares. J. bras. psiquiatr., Rio de Janeiro, v. 55, n.3, 2006 .

CHALUB, M.; TELLES, L.de B., Álcool, drogas e crime. Rev. Bras. Psiquiatr, São Paulo, v. 28, supl. 2, out., 2006.

CHODOROW, N. Psicanálise da maternidade: uma crítica a Freud a partir da mulher. Rio de Janeiro: Rosa dos Tempos, 1990.

COLLIÈRE, M. F. Promover a vida. Lisboa: Sindicato dos Enfermeiros Portugueses, 1989.

COLLET, N.; OLIVEIRA, B. R. G. Manual de enfermagem em pediatria. Goiânia: AB, 2002.

Conselho Nacional de Direitos da Criança e do Adolescente - CONANDA. Diretrizes nacionais para a política de atenção integral à infância e à adolescência. Brasília: Conanda, 2000.

CORSI, J. (Org.). Maltrato y abuso en el âmbito doméstico. Buenos Aires: Paidós, 2003. 
CORSI, J. (Org.). Violencia familiar: una mirada interdisciplinaria sobre un grave problema social. Buenos Aires: Paidós, 1997.

COSTA, A. de. Cenas de meninas e meninos no cotidiano institucional da educação infantil: um estudo sobre as relações de gênero . Dissertação (Mestrado - Universidade Federal de Santa Catarina, Florianópolis, 2004.

COSTA, M. C. O.; CARVALHO, R. C. de; BÁRBARA, J. de F. R. S.; SANTOS, C. A. S. T.; GOMES, W. de A.; SOUSA, H. L. de. O perfil da violência contra crianças e adolescentes, segundo registros de Conselhos Tutelares: vítimas, agressores e manifestações de violência. Ciênc. saúde coletiva, Rio de Janeiro, v.12, n.5, set./out. 2007.

COUTINHO, M. L. R. Tecendo por trás dos panos: a mulher brasileira nas relações familiares. Rio de Janeiro: Rocco, 1994.

CRAIG, S. T. J.; WINSTON, T. J. The effect of social support on prenatal care. J ournal of Applied Behavioral Science, v.25, p.79-98, 1989.

DAY, V. P.; TELLES, L. E. de B.; ZORATTO, P. H.; AZAMBUJ A, M. R. F de; MACHADO, A.; SILVEIRA, M. B.; DEBIAGGI, M.; REIS, M. de G.; CARDOSO, R. G.; BLANK, P. Violência doméstica e suas diferentes manifestações. Revista de Psiquiatria do Rio Grande do Sul, Rio Grande do Sul, v.25, supl. 1, p. 9-21, 2003.

DESLANDES, S. F. Atenção a crianças e adolescentes vítimas de violência doméstica: análise de um serviço. Caderno de Saúde Pública, v.10, Suppl 1, p.177-87, 1994a.

- Prevenir a violência: um desafio para profissionais de saúde. Rio de Janeiro: FIOCRUZ/ENSP/CLAVES, 1994b.

DESLANDES, S. F.; GOMES, R.; SILVA, C. M. F. P. Caracterização dos casos de violência doméstica contra a mulher atendidos em dois hospitais públicos do Rio de Janeiro. Cadernos de Saúde Pública, Rio de Janeiro, v.16, p.129-137, 2000.

DIX, T. H.; LOCHMAN, J. E. Social cognition and negative reactions to children: a comparation of mothers of aggressive and nonaggressive boys. J ournal of Social and Clinical Psychology, n.9, p. 418-438, 1990. 
DJEDDAH, C.; FACCHIN, P.; RANZATO, C.; ROMER, C. Child abuse: current problems and key public health challenges. Soc. Sci. Med., v.51, p.905-15, 2000.

DOSSI, A. P.; SAlIBA, O.; GARBIN, C. A. S.; GARBIN, A. J. I., Perfil epidemiológico da violência física intrafamiliar: agressões denunciadas em um município do Estado de São Paulo, Brasil, entre 2001 e 2005. Cad. Saúde Pública, Rio de Janeiro, v. 24, n. 8, ago. 2008.

DUGGAN, A.; FUDDY, L.; MCFARLANE, E.; BURRELL, L.; WINDHAM, A.; HIGMAN, S. Evaluating a statewide home visiting program to prevent child abuse in at-risk families of newborns: fathers. Participation and outcomes.

Child Maltreat, n.9, p.3-17, 2004.

FARINATTI. F; BIAZUS, D. B.; LEITE, M. B. Abuso físico: fundamentação conceitual. In: FARINATTI, F.; BIAZUS, D. B.; LEITE, M. B. editores. Pediatria social - a criança maltratada. Rio de Janeiro: MEDSI, p. 1131, 1993.

FENELON, G. M. Autoridade e amor na comunicação intrafamiliar de adolescentes com dificuldades escolares. Revista da UFG, Goiás, v.6, n. 1, jun., 2004.

FERREIRA, A. B. H. Novo Aurélio Século XXI: o dicionário da língua portuguesa. 3. ed. Rio de Janeiro: Nova Fronteira, 1999.

FERREIRA, A. L. Acompanhamento de crianças vítimas de violência: desafios para o pediatra. Rio de Janeiro. Jornal de Pediatria, Rio Grande do Sul, v. 81, supl. 5, 5173-5180, 2005.

FERREIRA, C. L. L.; CARTANA, M. H. F. A enfermagem e o cuidado de crianças vítimas de abuso e exploração sexual. Rev. Texto e Contexto Enferm, Santa Catarina, v.12, n.2, p.230-37, 2003.

FERREIRA, E. A. P. I rmãos que cuidam de irmãos na ausência dos pais: um estudo sobre desempenho de tarefas domésticas e interação entre irmãos. Tese de Mestrado, Universidade de Brasília, Brasília, 1991.

FINKELHOR, D.; ORMROD, R.; TURNER, H.; HAMBY, S. L. The victimization of children and youth: a comprehensive, national survey. Child Maltreat, n.10, p.5-25, 2005. 
FONTANELLA, B. J. B.; RICAS, J.; TURATO, E. R. Amostragem por saturação em pesquisas qualitativas em saúde: contribuições teóricas. Caderno de Saúde Pública, Rio de Janeiro, v. 24, n. 1, jan., p.17-27, 2008.

GALDURÓZ, J. C. F.; NOTO, A. R.; CARLINI, E. A. IV Levantamento sobre uso de drogas entre estudantes de 1ㅇ e 20 graus em 10 capitais brasileiras. São Paulo: CEBRID/Universidade Federal de São Paulo-Escola Paulista de Medicina, 1997.

GARCÍA-MORENO, C.; JANSEN, H. A. F. M.; ELLSBERG, M.; HEISE, L.; WATTS, C. H. Prevalence of intimate partner violence: findings from the WHO multi-country study on women's health and domestic violence. Lancet, London, v. 368, n. 9543, p. 1260-1269, 2006.

GIDDENS, A. A transformação da intimidade. São Paulo: UNESP, 1993.

GILBERT, L. A.; BROWNSON, C. Current perspectives on women's multiple roles. J ournal of Career Assessment, v.6, p.433-450, 1998.

GLAT, R. Somos iguais a vocês: depoimentos de mulheres com deficiência mental. Rio de Janeiro (RJ): Agir, p.31, 1989.

GOES, Ariel. Pisam nas flores e não dizemos nada?, 2002. Disponível em: <http: //www.groups.google.com/groups? q=violencia+dom\% C3\% A9st ica+adolesc ente\&hl> Acesso em: 28 ago. 2009.

GOLDMAN, J.; SALUS, M. K.; WOLCOTT. D.; KENNEDY, K. Y. A coordinated response to child abuse and neglect: the foundation for practice. Child abuse and neglect user manual series. Washington: U.S. Department of Health and Human Services, 2003.

GOLDSTEIN, J.; FREUD, A.; SOLNIT, A. J. No interesse da criança? São Paulo: Martins Fontes, 1987.

GOMES, R.; DESLANDES, S. F.; VEIGA, M. M.; BHERING, C.; SANTOS, J . F. C. Por que as crianças são maltratadas? Explicações para a prática de maus-tratos infantis na literatura. Caderno de Saúde Pública, v.18, n.3, Rio de Janeiro, mai/jun, p.707-14, 2002. 
GOMIDE, P. I. C. Crianças e adolescentes em frente à TV: o que e quanto assistem de televisão. Psicologia Argumento, v.30, p. 17-28, 2002.

- Efeitos de filmes violentos em comportamento agressivo de crianças e adolescente. Revista: Psicologia Reflexão e Crítica, v.13, n.1, p.127-141, 2000.

HEISE, L. Gender-based abuse: the global epidemic. Cadernos de Saúde Pública, Rio de Janeiro, v.10, p.135-145, 1994.

HEYMAN, R. E.; SLEP, A. M. Risk factors for family violence: introduction to the special series. Aggress Violent Behav. v.6, p.115-9, 2001.

HIJ AR-MEDINA, M.; FLORES-REGATA， L.; VALDEZ-SANTIAGO, R.; BLANCO, J. Atención médica de lesiones intencionales provocadas por la violencia familiar. Salud Publica Mex, Morelos, v.45, n.4, p.252-8, 2003.

HOCHGRAF, P. B.; BRASILIANO, S. Mulheres farmacodependentes: uma experiência brasileira. Álcool e drogas sem distorção: Programa Álcool e Drogas (PAD) do Hospital Israelita Albert Einstein [On line] março 2004. Disponível em: <http://www.einstein.br/alcooledrogas>. Acesso em: 15 out. 2008.

INSTITUTO BRASILEIRO DE GEOGRAFIA E ESTATíSTICA-IBGE. Pesquisa nacional por amostra de domicílios: indicadores sociais. Rio de Janeiro: IBGE, 2007.

INSTITUTO DE PESQUISA ECONÔMICA APLICADA-IPEA. Levantamento nacional de abrigos para crianças e adolescentes da rede SAC. 2007. Disponível em: <http://www. portaldovoluntario.org.br/press/ uploadArquivos/109726162757.pdf>. Acesso em: 15 out. 2008.

JANÉ, M. C.; ARANEDA, N.; VALERO, S.; DOMĖNECH, E. Prevalence of behavioral symptoms in catalan preschool children: relationship of child, parent and family variables. In: International Congress of European Society for Child and Adolescent Psychiatry, 11, 1999, Hamburg. Anais do International Congress of European Society for Child and Adolescent Psychiatry. Hamburg, 1999.

JUNQUEIRA, M. F. P. S. Violência e abuso sexual infantil: uma proposta clínica. Cad. psicanál., v.18, n.21, p.209-26, 2002. 
KASSAM-ADAMS, N.; FEIN, J.A. Posttraumatic stress disorder and injury. Clin. Ped. Emerg. Med., n.4, p. 148-55, 2003.

KEARNEY, M.; MURPHY, S.; ROSENBAUM, M. Mothering on crack cocaine: a grounded theory analysis. Social Science Medicine, v.38, n.2, p.351$61,1994$.

KLIKSBERG, Bernardo. Por uma economia com face mais humana. Brasília: UNESCO, 2003.

KRUG, E. G.; DAHLBERG, L. L.; MERCY, J. A.; ZWI, A. B.; LOZANO, R. World report on violence and health. Geneva: World Health Organization, 2002.

LÉVI-STRAUSS, Claude. As estruturas elementares do parentesco. Petrópolis: Vozes; São Paulo: EDUSP, 1976.

LEWIS, M. Social development in infancy and early childhood. Em J.D. Osofsky (Org.), Handbook of infant development, New York: Wiley, p. 419-493, 1987.

LIMA, M. S. Epidemiologia e impacto social. Rev. Bras. Psiquiatr., São Paulo, v.21, p.1-5, 1999.

LOURO, G. L. O corpo educado: pedagogias da sexualidade. 2 a ed. Belo Horizonte: Autêntica; p.11, 2001.

LOVETT, B. B. Child sexual abuse disclosure: maternal response and other variables impacting the victim. Child. Adolesc. Social Work J., n.21, p. 355-71, 2004.

MARMO, D. B.; DAVOLI, A. OGIDO, R. Violência doméstica contra a criança. J ornal de Pediatria, v.71, p.313-316, 1995.

MERRICK, J.; BROWNE, K. D. Child abuse and neglect: a public health concern. Rev. Public Health, São Paulo, n.27, p. 279-93, 1999.

MIAN, M. World report on violence and health: what it means for children and pediatricians. J ornal de Pediatria, Rio Grande do Sul, n.145, p.14-9, 2004. 
MINAYO, M. C. S.; DESLANDES, S. F. A complexidade das relações entre drogas, álcool e violência. Cadernos de Saúde Pública, v.14, p.35-42, 1998.

MINAYO, M. C. S.; SOUZA, E. R. É possível prevenir a violência? Reflexões a partir do campo da saúde pública. Rev. C. S. Col., Rio de Janeiro, v.4, n.1, p.9-15, 1999.

. Violência e saúde como um campo interdisciplinar e de ação coletiva. História, Ciência e Saúde IV, v.3, p.513-531, 1998.

(Org.). Violência sob o olhar da saúde: a infrapolítica da contemporaneidade brasileira. Rio de Janeiro: FIOCRUZ, 2003.

MINAYO, M. C. S; ASSIS, S. G. Saúde e violência na infância e na adolescência. J. Pediatria, Rio de Janeiro, v.70, n.5, p.263-6, 1994.

MINAYO, M. C. S. A difícil e lenta entrada da violência na agenda do setor saúde. Cadernos de Saúde Pública, Rio de Janeiro, v. 20, n. 3, p. 646647, $2004 a$.

. Violência: um problema para a saúde dos brasileiros. In: Ministério da Saúde (BR). Impacto da violência na saúde dos brasileiros. Brasília (DF), p.9-41, 2005.

O desafio da conhecimento: pesquisa qualitativa em saúde. 9. ed. São Paulo: Hucitec, 2006.

- O significado social e para a saúde da violência contra crianças e adolescentes. In: WESTPHAL, M.F.( Org.). Violência e criança. São Paulo: Editora da Universidade de São Paulo, p. 95-11, 2002.

Violência: um tema que a realidade social impõe à atenção médica. Revista Digital de Educação Permanente em Saúde, v.1, n.1, p.3, 2004b. Disponível em: <www.abemeducmed.org.br/ publicacoes/revista_ digital/pdf_vol_1_2004/minayo.pdf>. Acesso em: 23 ago. 2008.

A violência na adolescência: um problema de saúde pública. Cad. Saúde Pública, Rio de Janeiro, v.6, n.3, p.278-87, 1990. 
MINUCHIN, SALVADOR - Famílias: Funcionamento \& Tratamento. Porto Alegre: Artes Médicas, p. 25-69, 1990.

MONTEIRO, C. A. Velhos e novos males da saúde no Brasil. São Paulo: Hucitec, 2000.

MONTEIRO, L. F.; PHEBO, L. B. Maus-tratos contra crianças e adolescentes. Proteção e prevenção. Guia para profissionais de saúde. Rio de Janeiro: Associação Brasileira de Proteção à Infância e Adolescência, 1992.

MORAES, C. L.; REICHENHEIM, M. E. Domestic violence during pregnancy in Rio de Janeiro, Brazil. Int. J. Gynaecol. Obstet., v. 79, p.269-77, 2002.

MOREIRA, D. A. O método fenomenológico da pesquisa. São Paulo: Pioneira Thomson, 2002.

MOREIRA, I. O doente terminal em contexto familiar: uma análise da experiência de cuidar vivenciada pela família. Coimbra: Formasau, p.1550, 2001.

MOURA, S.; ARAÚJO, M. A maternidade na história e a história dos cuidados maternos. Psicologia Ciência e Profissão, v.24, n.1, p. 44-55, 2004.

NARVAZ, M. Abusos sexuais e violências de gênero. In: NUNES, M. R. (Org.). Os direitos humanos das meninas e das mulheres: Enfoques feministas. Porto Alegre: Assembléia Legislativa do Rio Grande do Sul, p. 29-33, 2002.

NARVAZ, M. G.; KOLLER, S. H. Mulheres vítimas de violência doméstica. Psico. Porto Alegre, PUCRS, v.37, n.1, p. 7-13, jan./abr., 2006.

NASCIMENTO, P. G. "Ser homem ou nada": diversidade de experiências e estratégias de atualização do modelo hegemônico de masculinidade em Camaragibe/PE. Dissertação de Mestrado, Programa de Pós-graduação em Antropologia, Universidade Federal de Pernambuco, Recife, 1999.

NOEL, N. L.; YAM, M. Domestic violence. The pregnant battered women. Nurs Clin North Am. v.27, p.871-84, 1992. 
NURCO, D.; LERNER, M. Vulnerability to narcotic addiction: Family structure and funcioning. Journal of Drug Issues, v.26, p.1007-1025, 1996.

OLIVEIRA, T. T. S. S.; CALDANA, R. H. L. Mães psicólogas ou psicólogas mães: vicissitudes na educação dos filhos. Estudo de Psicologia, Natal, v.9, n. 3, p. 585-593, 2004.

OLSON, L.; ANCTIL, C.; FULLERTON, L.; BRILLMAN, J.; ARBUCKLE, J.; SKLAR, D. Increasing emergency physician recognition of domestic violence. Ann. Emerg. Med., v.27, p.741-6, 1996.

ORGANIZAÇÃO MUNDIAL DA SAÚDE - OMS. Relatório mundial sobre violência e saúde. Genebra: OMS, p. 48, 2002.

ORGANIZAÇÃO PANAMERICANA DE SAÚDE. I nforme mundial sobre a violência e a saúde. Washington: Organização Pan-americana de Saúde, 2003.

PACHeCO, J.; AlvarengA, P.; RePPOld, C.; PICCININI, C. A.; HUTZ, C. S. Estabilidade do comportamento anti-social na transição da infância para a adolescência: uma perspectiva desenvolvimentista. Psicologia: Reflexão e Crítica, Rio Grande do Sul, v.18, n.1, p.55-61, 2005.

PARKER, R. A mãe dividida: a experiência da ambivalência na maternidade. Tradução. C.D.X. Lima. de. Rio de Janeiro: Record/ Rosa dos tempos, 1997.

PATTERSON, G.R.; BANK, L. Some amplifying mechanisms for pathologic processes in families. In: GUNNAR, M.R.; THELEN, E. (Eds.) Systems and development: the minnesota symposia on child psychology. Hillsdale: Erlbaum, v. 22, p. 16-20, 1989.

PEIXOTO, J. A. M. Os direitos humanos, o princípio da dignidade humana e as políticas públicas de prevenção e repressão aos crimes de violência doméstica no município de Lajeado. 2006.165 f. Dissertação (Mestrado em Direitos Sociais e Políticas Públicas) Universidade de Santa Cruz do Sul, Santa Cruz do Sul, 2006.

PETRIODOU, E.; BROWNE, A.; LICHTER, E.; DEDOUKOU, X.; ALEXE, D.; DESSYPRIS, N. What distinguishes unintentional injuries from injuries due 
to intimate partner violence: a study in Greek ambulatory care settings. I nj. Prev. v.8, p.197-201, 2002.

PRIULI, R. M. A.; MORAES, M. S. de. Adolescentes em conflito com a lei. Ciênc. Saúde Coletiva, Rio de Janeiro, v.12, n.5, set./out., 2007.

RABELO; CALDAS, JUNIOR. Violência contra a mulher, coesão familiar e drogas. Rev. Saúde Pública. v.41, n.6, São Paulo, dez., 2007.

RAVAZZOLA, M. C. Historias infames: los maltratos en las relaciones. Buenos Aires: Paidós, 1999.

Violencia familiar: el abuso relacional como un ataque a los derechos humanos. Sistemas Familiares, v.23, p.29-42, 1997.

REICHENHEIM, M. E.; DIAS, A. S.; MORAES, C. L. Co-ocorrência de violência física conjugal e contra filhos em serviços de saúde. Rev. Saúde Pública, São Paulo, vol.40, n.4, p.595-603, ago., 2006.

REI CHENHEI M, M. E.; HASSELMANN, M. H.; MORAES, C. L. Consequências da violência familiar na saúde da criança e do adolescente: contribuições para a elaboração de propostas de ação. Ciência e Saúde Coletiva, v.4, p.109-21, 1999.

RIBEIRO, M. A.; FERRIANI, M. G. C.; REIS, J. N. Violência sexual contra crianças e adolescentes: características relativas à vitimização nas relações familiares. Cad. Saúde pública, Rio de Janeiro, v.20, n.2, p.456-464, 2004.

ROQUE, E. M. de S. T. A violência na família contra crianças e adolescentes e a percepção dos operadores do direito, na comarca de J ardinópolis-SP. 2001. 226f. Dissertação (Mestrado em Enfermagem em Saúde Pública) - Escola de Enfermagem de Ribeirão Preto, Universidade de São Paulo, Ribeirão Preto, 2001.

. Estudo das famílias de crianças e adolescentes, vítimas de violência, que sofreram intervenções da justiça, em comarca de vara única - Estado de São Paulo - Brasil. 2006. 278f. Tese (Doutorado em Enfermagem em Saúde Pública) - Escola de Enfermagem de Ribeirão Preto, Universidade de São Paulo Ribeirão Preto, 2006. 
ROSSMAN, B. B. R.; HUGHES, H. M.; ROSENBERG, M. S. Children and interparental violence: the impact of exposure. Philadelphia: Brunner/ Mazel, 1999.

RUTTER, M. Psychosocial resilience and protective mechanisms. American J ournal Orthopsychistry, v.57, n.3, p.316-331, 1987.

SACRAMENTO, L. de Te; REZENDE, M. M. Violências: lembrando alguns conceitos. Aletheia, Canoas, n. 24, p.95-104, dez. 2006.

SAMPAIO, J.; SANTOS, M. de F. de S.; SILVA, M. R. F. da. A representação social da maternidade de crianças em idade escolar. Psicol. cienc. prof. Brasília, v.28, n.1, mar., 2008.

SANCHEZ, R. N.; MINAYO, C. S. Violência contra Crianças e Adolescentes: Questão histórica, social e saúde. In: LIMA, C. A. et al., (Coords.). Violência faz mal à saúde: série $B$ - textos básicos de saúde. Brasília: Ministério da Saúde, p.29-38, 2006.

SANTOS, B. Pela Mão de Alice O Social e o Político na Pós-modernidade. São Paulo: Cortez Editora, 1996.

SARTI, C. A. A família como um espelho: um estudo sobre a moral dos pobres. São Paulo: Cortez, 2003.

SCAVONE, L. Maternidade: transformações na família e nas relações de gênero. In: SCAVONE, L. Dar a vida e cuidar da vida: feminismo e ciências sociais. São Paulo: UNESP, p. 171-186, 2004.

SCHENKER, M.; MINAYO, M. C. S.A implicação da família no uso abusivo de drogas: uma revisão crítica. Ciência \& Saúde Coletiva, v.8, n.1, p.299-306, 2003.

SCHRAIBER, L. B.; D'OLIVEIRA, A. F. P. L.; COUTO, M. T. Violência e saúde: estudos científicos recentes. Rev. Saúde Pública. São Paulo, v.40, n. esp., p.112-120, 2006.

SCOTT, J. W. A Mulher trabalhadora. In: DUBY, G.; PERROT, M. História das mulheres no ocidente: século XIX. Porto: Edições Afrontamento, 2001. 
SEGALEN, MARTINE. Sociologia da Família. Tradução de Ana Santos Silva. Lisboa: Terramar, p. 63-94, 1999.

SILVA, A. T. M. C. A reforma psiquiátrica em João Pessoa (PB): limites e possibilidades de transformação do trabalho para produzir saúde mental. [Tese de Doutorado] São Paulo (SP): Escola de Enfermagem/USP; 2003.

SILVA, L. M. P., NASCIMENTO C. A. D.; SILVA I. R.; GUIMARÃES, K. N. Violência doméstica contra crianças e adolescentes. Brasília: Ministério da Saúde, 2002.

SIQUEIRA, A. Pronta para brindar: consumo depois de uma década de baixo crescimento, a indústria está prestes a chegar à produção de 9 bilhões de litros de cerveja. Carta Capital, v.12, n.363, p.50-51,out., 2005.

SOARES, C.; OLIVEIRA, S. Gênero, estrutura ocupacional e diferenças de rendimento. In: Encontro Nacional de Estudos Populacionais, 14. Anais. Caxambu, 2004.

SORJ, B. Percepções sobre esferas separadas de gênero. In: ARAÚJ O, C.; SCALON, C., (Orgs.). Gênero, família e trabalho no Brasil. Rio de J aneiro: Fundação Getúlio Vargas, 2005.

SOUZA, A. M. N. A família e seu espaço: uma proposta de terapia familiar.Rio de Janeiro: Agir, 1997.

SPINDOLA, C. Mulher chefe de família. Florianopolis, 2005.

SPITZ, R. A. O primeiro ano de vida: um estudo psicanalítico do desenvolvimento normal e anômalo das relações objetais. São Paulo: Martins Fontes, p.99, 1979.

STANHOPE, M. Teorias e Desenvolvimento Familiar. In: STANHOPE, M. ; STRASBURGGER, V. C. Os adolescentes e a mídia: impacto psicológico. Porto Alegre: Artmed, p.491-510, 1999.

STRAUS, M. A.; GELLES, R. J. Physical violence in American families: risk factors and adaptations to violence in 8145 families. New Brunswick: Transaction Publisher, 1995. 
SWANSTON, H. Y.; PARKINSON, P. N.; O'TOOLE, B. I.; PLUNKETT, A. M.; SHRIMPTON, S.; OATES, R. K. Juvenile crime, aggression and delinquency after sexual abuse. BR. J. Criminol., v.43, p.729-49, 2003.

SZEJER, M. A escuta psicanalítica de bebês em maternidade. São Paulo: Casa do Psicólogo, 1999.

TOLEDO, C. Mulheres: O gênero nos une, classe nos divide. 2 ed. São Paulo: Instituto José Luis e Rosa Sundermann, p.148, 2003.

TORnARí A, M. L. G.; VANDEMEULEBROECKE, L.; COLPIN, H. Pedagogía Familiar. Montevideo: Ediciones Trilce, 2001.

TOSCANO, A. Jr. Um breve histórico sobre o uso de drogas. In: SEIBEL, S. D.; TOSCANO, A. Jr. Dependência de drogas. São Paulo: Atheneu, p.724, 2001.

TROCMÉ, N. M.; TOURIGNY, M.; MACLAURIN, B.; FALLON, B. Major findings from the Canadian incidence study of reported child abuse and neglect. Child Abuse \& Neglect, n.27, p. 1427-1439, 2003.

TUBERT, Silvia. Mulheres sem sombra: maternidade e novas técnicas reprodutivas. Rio de Janeiro: Record, p.121, 1996.

VALDEZ-ROJ AS J. C.; SALASAR-LIMA, A.; HERNÁNDEZ-MOREJ ON, E.; DMÍ NGUEZ-SANCHER, M.; TORRE-DIANEZ, R.; BARBOSA-RODRÍGUEZ, D. Violência Intrafamiliar. Enfoque de gênero. Rev. Cubana Med. Gen. I ntegr.v.18, n.4, p.248-50, 2002.

WAGNER, A. A. A família e a tarefa de educar: algumas reflexões a respeito das famílias tradicionais frente a demandas modernas. In: FÉRES-CARNEIRO, T. (Org.), Casal e família: arranjos e demandas contemporâneas (pp.27-33).Rio de Janeiro: PUC-Rio, 2003.

WAGNER, A., PREDEBON, J., MOSMANN, C., VEREZA, F. Compartilhar tarefas? Papéis e funções de pai e mãe na família contemporânea. Psicologia: teoria e pesquisa, v.21, n.2, p. 181-186, 2005.

WATTS, C.; ZIMMERMAN, C. Violence against women: global scope and magnitude. Lancet, London, v. 359, n. 9313, p. 1232-1237, 2002. 
WEBER, L. N. D.; VIEZZER, A. P.; BRANDENBURG, O. J. O uso de palmadas e surras como prática educativa. Estudos Psicol. v.9, p.22737, 2004.

WESTPHAL, M. F. (Org.). Violência e Criança. São Paulo: EDUSP, 2002.

WHALEY, L. F.; WONG, D. L. Enfermagem Pediátrica. Rio de Janeiro: Guanabara Koogan, p.21, 1989.

WIIST, W. H.; MCFARLANE, J. The effectiveness of an abuse assessment protocol in public health prenatal clinics. Am. J. Public Health, v.89, p.1217-21, 1999.

WINNICOTT, D. W. A Família e o desenvolvimento individual. São Paulo: Martins Fontes, 1993.

WOOD, G. L.; HABER, J. Pesquisa em Enfermagem: métodos, avaliação crítica e utilização. 4. ed. Rio de Janeiro (RJ ): Guanabara Koogan, 2001.

WORLD HEALTH ORGANIZATION (WHO). Department of Injuries and Violence Prevention. The economic dimensions of interpersonal violence prevention. Génève: World Health Organization, 2004a.

WORLD HEALTH ORGANIZATION (WHO). Injury: a leading cause of the global burden of disease. Genève: World Health Organization, 1999a. Disponível em: <http://www.who.int/violence_injury-prevention /index. html >. Acesso em: 14 set. 2008.

WORLD HEALTH ORGANIZATION. Global Status Report on Alcohol, 2004b. Disponível em: <http://www.who.int/substance_abuse/ publications/global_status_report_2004_overview.pdf $>$. Acesso em: 11 set. 2008.

WORLD HEALTH ORGANIZATION. Guidelines for medico-legal care for victims of sexual violence. Geneva: World Health Organization; 2003.

WORLD HEALTH ORGANIZATION. WHO recognizes child abuse as a major public health problem. Geneva: World Health Organization, 1999b. 
WORLD HEALTH ORGANIZATION. WHO Multi-country study on women's health and domestic violence against women. Geneva: World Health Organization, 2005.

WRIGHT, J. L.; CHENG, T.L. Successful approaches to community violence intervention and prevention. Pediatr. Clin. North Am., v.45, p.459-67, 1998.

ZANNON, C. M. L. C. O comportamento de crianças hospitalizadas e a rotina hospitalar: subsídios para atuação do psicólogo junto à equipe de pediatria. Tese de doutorado, Universidade de São Paulo, 1981. 


\section{ANEXO}

\section{ANEXO I - Aprovação pelo Comitê de Ética}
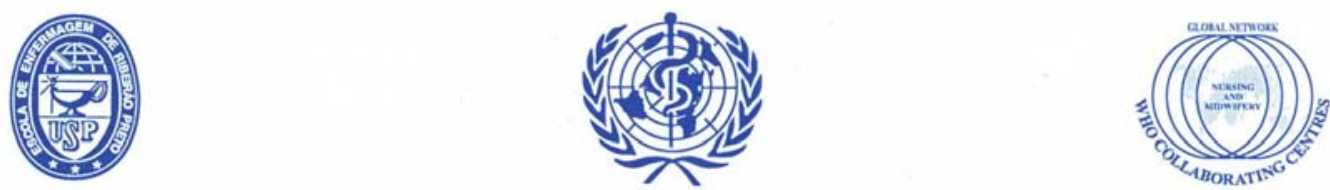

Escola de Enfermagem de Ribeirão Preto - Universidade de São Paulo

Centro Colaborador da Organização Mundial da Saúde para

o Desenvolvimento da Pesquisa em Enfermagem

Avenida Bandeirantes, 3900 - Campus Universitário - Ribeirão Preto - CEP 14040-902 - São Paulo - Brasil

FAX: (55) - 16 - 3633-3271 / TELEFONE: (55) - 16 - 3602-3382

\section{COMITÊ DE ÉTICA EM PESQUISA DA EERP/USP}

Of.CEP-EERP/USP - 219/2008

Ribeirão Preto, 18 de setembro de 2008

Prezada Senhora,

Comunicamos que o projeto de pesquisa, abaixo especificado, foi analisado e considerado APROVADO pelo Comitê de Ética em Pesquisa da Escola de Enfermagem de Ribeirão Preto da Universidade de São Paulo, em sua $109^{\mathrm{a}}$ Reunião Ordinária, realizada em 17 de setembro de 2008.

Protocolo: $\quad n^{\circ} 0946 / 2008$

Projeto: VIOLÊNCIA INTRAFAMILIAR: UM ESTUDO COM MÃES AGRESSORAS.

Pesquisadores: Ana Márcia Spanó Nakano

Daniela Borges Bittar

Em atendimento à Resolução 196/96, deverá ser encaminhado ao CEP o relatório final da pesquisa e a publicação de seus resultados, para acompanhamento, bem como comunicada qualquer intercorrência ou a sua interrupção.

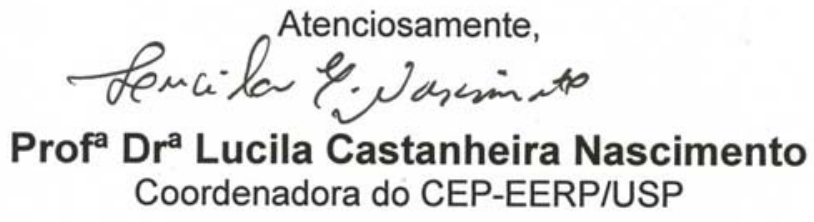

IIma. Sra.

Profa. Dra . Ana Márcia Spanó Nakano

Departamento de Enfermagem Materno-Infantil e Saúde Pública

Escola de Enfermagem de Ribeirão Preto - USP 


\section{APÊNDI CES}

\section{APÊNDICE A - Aspectos a serem contemplados na História de Vida}

\section{I dentificação:}

Nome (iniciais):

Idade:

Ocupação:

Nível de escolaridade:

Renda familiar:

№. de membros da família que moram juntos:

Desempregados:

\section{A) História de vida-tópica}

\section{Família de Origem}

Fale-me sobre como foi sua infância. (Com quem você viveu; como era o seu relacionamento com as pessoas da sua casa; como era/é seu relacionamento com seus pais; que tipo de atividades você fazia; convivência com a mãe - diferenças na forma como sua mãe tratava você e seus irmãos, o que gostaria que fosse diferente, fatos marcantes desta convivência).

O que você considera importante na relação pais e filhos? Você teve isto? Havia conflitos em sua casa?

O que você fazia quando alguma coisa a incomodava?

\section{Relação Conjugal}

Com quem você vive hoje?

Fale-me de seu (s) relacionamento (s) conjugal. (o que agradava e desagradava nesta relação, vinculo do parceiro com os filhos).

\section{Contexto da relação mãe e filhos}

Fale-me sobre o seu relacionamento com seu(s) filho(s) (Há preocupação com eles? Que tipo de preocupação eles Ihe dão? Desejo de ter filhos e se foram planejados. Tem ajuda de outras pessoas para cuidar dos filhos? Como é o relacionamento destas pessoas com seus filhos? $O$ que 
desagrada e agrada nesta relação? Como deve educar um filho? O que é ser mãe para você?).

Quando seus filhos fazem alguma coisa que a desagrada, como você age? O que deixa você ficar fora de si?

Você tem tempo para dedicar-se a si mesmo?

\section{B) Contexto da violência}

Há algum tipo de desavença/briga em casa?

Alguém faz uso de bebida alcoólica, cigarro ou outro tipo de droga em casa?

Você alguma vez na vida sentiu-se maltratada, humilhada ou agredida por alguém próximo a você?

Na sua vida, alguém já bateu, deu tapas, chutou ou machucou você fisicamente ou de alguma outra forma? Por exemplo: ameaças de abuso incluindo o uso de arma; agressão ou violência com objetos; tapas; empurrões; pontapés, contusões, socos, cortes; queimaduras, fraturas. Alguma vez na vida você já agrediu alguém? Conte-me como foi. 


\title{
APÊNDI CE B - Solicitação de autorização para a pesquisa
}

\author{
UNI VERSI DADE DE SÃO PAULO \\ ESCOLA DE ENFERMAGEM DE RI BEI RÃO PRETO \\ Centro Colaborador da OMS para o Desenvolvimento da Pesquisa em Enfermagem \\ Departamento Enfermagem Geral e Especializada \\ Campus de Ribeirão Preto \\ CEP: 14049-902 - Ribeirão Preto - SP - Brasil
}

Ribeirão Preto, 09 de maio de 2008.

\section{Exmo. Sr. Lupercio Pedro Ficoto,}

Presidente da Fundação PROMAR -

Projeto Marcenaria da Música de Jardinópolis/SP.

Prezado Sr. Lupercio Pedro Ficoto,

Venho, por meio deste, encaminhar o projeto da Enfermeira Daniela Borges Bittar, mestranda do Programa de Enfermagem em Saúde Pública da EERP-USP, intitulado “Violência I ntrafamiliar: um estudo com mães agressoras", para apreciação e manifestação da Fundação PROMAR - Projeto Marcenaria da Música de Jardinópolis/SP - sob sua responsabilidade.

Tal projeto será desenvolvido como dissertação a ser apresentada para obtenção do título de Mestre em Enfermagem. Esta solicitação se faz necessária uma vez que a investigação envolverá os indivíduos participantes do Projeto de Extensão "Intervenções breves para pessoas que abusam de álcool e drogas" ligado ao PROMAR.

Trata-se de um estudo que tem por objetivo compreender a violência perpetrada por mães junto aos seus filhos, tendo por base seu contexto histórico e social.

Os potenciais participantes serão os indivíduos femininos, adultos, participantes do Projeto de Extensão supracitado. Os dados serão coletados no local em que se realiza o projeto, Igreja da Lapa de Jardinópolis, através de entrevista. 
Gostaria de salientar que este projeto deverá ser encaminhado, após sua apreciação e concordância, ao Comitê de Ética da Escola de Enfermagem de Ribeirão Preto - EERP/USP.

Atenciosamente,

Daniela Borges Bittar

Enfermeira do HCFMRP

Mestranda da EERP/USP
Ana Márcia Spanó Nakano

Profa. Dra. Dep. Enfermagem

em Saúde Pública - EERP/USP. 
JARDINÓPOLIS, 14 de maio de 2008.

Venho, por meio deste, manifestar o aceite do Projeto de Mestrado "Violência Intrafamiliar: um estudo com mães agressoras", encaminhado pela enfermeira Daniela Borges Bittar à Fundação PROMAR - Projeto Marcenaria da Música de Jardinópolis/SP - sob minha responsabilidade.

Tal projeto será desenvolvido como dissertação a ser apresentada para obtenção do Título de Mestre em Enfermagem. Esta solicitação se faz necessária uma vez que a investigação envolverá os indivíduos participantes do Projeto de Extensão "Intervenções breves para pessoas que abusam de álcool e drogas" ligado ao PROMAR.

Atenciosamente,

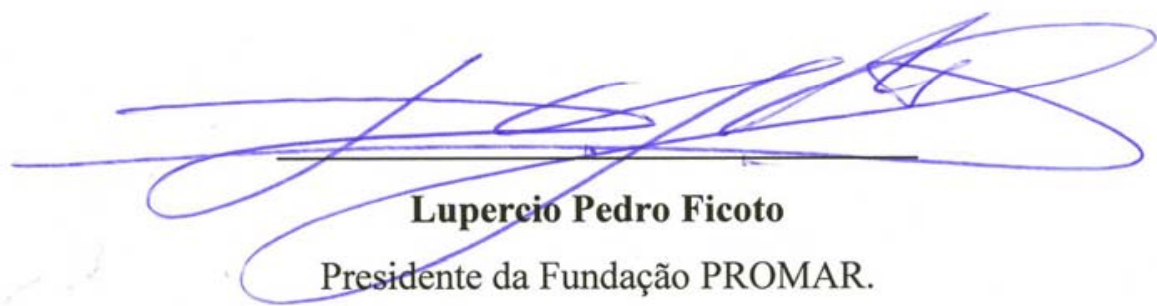




\section{APÊNDICE C - Termo de Consentimento Livre e Esclarecido}

\section{Pesquisadores}

Orientadora: Profa. Dra. Ana Márcia S. Nakano

Orientando(a): Daniela Borges Bittar

\section{I nformações sobre a pesquisa}

Estamos convidando você a participar de uma pesquisa que busca compreender as relações mãe-filho no sentido de ajudá-los em sua convivência.

Para isso, queremos conhecer como você convive em sua casa hoje em dia e como era sua convivência com sua família quando você era criança; ou seja, faremos algumas perguntas sobre seus dados pessoais, sua família, sua infância, sua relação com seu parceiro e com seus filhos.

Essa entrevista irá durar aproximadamente 30 minutos, será realizada em local reservado no espaço da Igreja da Lapa de Jardinópolis e Ihe será garantida uma cópia desse termo.

Você pode aceitar ou não participar; e, caso aceite, assumimos o compromisso de manter sigilo/segredo sobre sua identidade, assim como garantimos que você não terá nenhum gasto participando do estudo. A qualquer momento, caso não seja mais do seu interesse participar, haverá a possibilidade de retirar este consentimento e isto não interferirá em seu atendimento aqui no serviço nem em nenhum outro serviço social ou de saúde.

Agradecemos sua colaboração e nos colocamos a disposição para os esclarecimentos ou dúvidas que surgirem, além de disponibilizarmos um profissional capacitado do Grupo de Apoio, o psicólogo, caso você ache necessário. 
Sua participação será muito importante para nós, pois esta pesquisa ajudará no desenvolvimento de ações e estratégias junto às famílias dessa comunidade.

Caso você queira se comunicar conosco o endereço da Escola de Enfermagem de Ribeirão Preto-USP é Avenida Bandeirantes, №. 3900, fone (16) 36023405.

Atenciosamente,

$\mathrm{Eu}$, tendo recebido as informações acima e ciente do exposto, aceito participar da pesquisa de forma livre e esclarecida, assinando este documento com a garantia de que meu nome será preservado.

Ribeirão Preto, de de 2008. 


\section{APÊNDICE D - Breve perfil dos sujeitos do estudo}

S1

- I dade: 40

- Ocupação: Do lar

- Nível de escolaridade: 7aㅡ série incompleta

- Estado civil: Casada

- Renda familiar: $\mathrm{R} \$ 380,00$

- Número de membros que moram juntos: 6

- Desempregados: 1

- Número de filhos: 4 (19a; 16a;14a e 13a)

- História: Possui 13 irmãos, sendo 3 falecidos. Não conviveu com sua mãe verdadeira; em seu terceiro dia de vida sua mãe faleceu devido à violência conjugal. Foi criada pela tia paterna, pois o pai era alcoólatra, morreu há alguns anos. Faz uso de álcool e drogas desde a adolescência. Havia membros da família que também eram alcoólatras e refere que sofria violência na infância. Atualmente, mora com o marido e 4 filhos, com os quais entra em conflito constantemente. Foi obrigada a se casar porque estava grávida, porém refere ser infeliz e ser homossexual. Refere ter um relacionamento "cruel" com os filhos, envolvendo muita violência de ambas as partes e uso de drogas. 
- I dade: 47

- Ocupação: Do lar

- Nível de escolaridade: 4ạ série

- Estado civil: Separada

- Renda familiar: $\mathrm{R} \$ 300,00$

- Número de membros que moram juntos: 7

- Desempregados: 3

- Número de filhos: 6 (27a; 24a; 19a; 17a e 2 mortos)

- História: Morou com os pais até 7 anos de idade, quando perdeu o pai, alcoólatra; sendo, então, entregue pela mãe para sua madrinha a criar. A mãe não tinha condições de criá-la. Sofria violência na infância e refere sentir falta da mãe que mora em outra cidade. Convivia com violência conjugal dos pais substitutos. Mora, atualmente, com os filhos e refere haver muita violência em casa. É alcoólatra e sempre está embriagada durante as reuniões do grupo de apoio. Presenciamos um episódio de violência cometida por ela contra o neto durante uma das reuniões. 
- I dade: 41

- Ocupação: Do lar

- Nível de escolaridade: 4ạ série

- Estado civil: Relação estável

- Renda familiar: $R \$ 380,00$

- Número de membros que moram juntos: 5

- Desempregados: 1

- Número de filhos: 7 (24a; 21a; 19a; 16a; 13a; 3a; 1a)

- História: Sempre morou com os pais na infância, na cidade de Jardinópolis, juntamente com os 5 irmãos. Sofria violência na infância tanto pelo pai quanto pela mãe e trabalhava na roça. Presenciou violência conjugal, por ciúmes dos pais. Possui, atualmente, uma relação estável há 23 anos, mas refere que nunca foi um relacionamento bom. Sofre agressões do marido, usuário de álcool e drogas, que também agride as crianças. Tem um filho preso e uma filha que se casou com o intuito de sair de casa; sendo que, os filhos fazem uso de drogas. Refere que não queria ser mãe e não planejou ter filhos; já tentou abortar sem sucesso. 
- I dade: 31

- Ocupação: Desempregada

- Nível de escolaridade: $2^{\circ}$ grau incompleto

- Estado civil: Relação Estável

- Renda familiar: $\mathrm{R} \$ 380,00$

- Número de membros que moram juntos: 3

- Desempregados: 2

- Número de filhos: 3 (11a; 6a; 3a )

- História: Sempre morou com os pais na infância e não tinha um bom relacionamento com a mãe, que a violentava física e psicologicamente. Refere não sentir falta da mãe. Também já foi agredida pelo pai e concorda com a atitude dele, pois acredita ter cometido um erro e ele deveria corrigi-la através de violência física. Tentou suicídio devido a falta de carinho da mãe. Casou-se com 19 anos com o primeiro marido. Começou a usar álcool com 12 anos, pois via a mãe beber. Ficou alcoolizada a primeira vez com 15 anos e tornou-se alcoólatra. Já foi agredida pelo marido. Acredita ser importante o diálogo no relacionamento mãe-filho. Separou-se do primeiro marido e perdeu a guarda dos filhos devido ao alcoolismo. Em seguida, casou-se novamente. Refere sentir muita falta dos filhos e acha que ser mãe é maravilhoso. 
S5

- I dade: 22

- Ocupação: Do lar

- Nível de escolaridade: 2ạ série

- Estado civil: Separada

- Renda familiar: $\mathrm{R} \$ 400,00$

- Número de membros que moram juntos: 5

- Desempregados: 0

- Número de filhos: 3 (5a; 9meses; 3a)

- História: Sempre morou com os pais na infância e não tinha um bom relacionamento com eles. Sofria agressões principalmente pela mãe. Tem 9 irmãos, sendo que um deles foi estuprado aos 14 anos. Começou a usar álcool e drogas aos 13 anos e presenciava uso de álcool pelos pais. Fala abertamente sobre o uso de crack, maconha, cocaína, álcool, cigarro e chegou a vender objetos pessoais para comprar drogas. Atualmente mora sozinha, separou-se do marido, usuário de drogas, que também a agredia. Refere ser contra a violência, porém comete violência física contra os filhos algumas vezes. 
- I dade: 22

- Ocupação: Do lar

- Nível de escolaridade: 3ạ série

- Estado civil: Solteira

- Renda familiar: 0

- Número de membros que moram juntos: 3

- Desempregados: 1

- Número de filhos: 1 (5 ou 6 abortos e está grávida)

- História: Foi criada pela avó, pois a mãe faleceu quando ela tinha 7 anos de idade e o pai foi embora em seguida. A mãe era alcoólatra e tinha um relacionamento ruim com sua irmã, que usava drogas. Sua avó a agredia, cometendo violência física, psicológica e também negligência, pois ficava sozinha durante o dia todo enquanto trabalhavam; além disso, sua avó a tratava diferente dos outros netos. Devido às agressões da avó, foi morar com uma tia, depois com uma amiga, perdendo a referência materna. Com 16 anos se casou e logo depois separou-se e se casou novamente. Esse último marido a agredia, assim como sua sogra. Trabalhava na roça para sustentar a casa, pois o marido não trabalhava. Chegou a ter um aborto devido à agressão do marido. Atualmente se separou e namora, contudo refere que não gosta do atual namorado. Seu relacionamento com o filho às vezes é bom, às vezes não. Ela comete violência física e psicológica, mas diz que não bate nele como sua avó a agredia: "mas bater para machucar igual minha vó, isso não". 
- I dade: 37

- Ocupação: Auxiliar de serviços gerais

- Nível de escolaridade: Analfabeta

- Estado civil: Separada

- Renda familiar: $R \$ 200,00$

- Número de membros que moram juntos: 5

- Desempregados: 2

- Número de filhos: 7 (18a, 16a, 15a, 12a, 7a, 3a, 3a)

- História: Foi criada pela mãe e pelo padrasto e refere ter tido uma infância ruim. Não tinha um bom relacionamento com a mãe. Começou a trabalhar na roça com 8 anos. Quando tinha 13 anos, o padrasto foi preso e ela e o irmão tiveram que sustentar toda a família. Sua irmã foi estuprada pelo padrasto dos 7 aos 14 anos, quando engravidou. Refere que seu sobrinho tem 27 anos hoje, está preso e tem problemas mentais. A irmã tem 40 anos, é doente, acamada e não reconhece ninguém, devido ao estupro. Com 13 anos, o padrasto tentou violentá-la sexualmente e ela fugiu com o namorado. Era agredida por ele e, atualmente, vive com os filhos sozinha. Um dos filhos usa drogas e está na FEBEM. 
- I dade: 30

- Ocupação: Do lar

- Nível de escolaridade: 6a série

- Estado civil: Relação estável

- Renda familiar: $\mathrm{R} \$ 200,00$

- Número de membros que moram juntos: 6

- Desempregados: 0

- Número de filhos: 3 (12a, 7a, 5a e está grávida)

- História: Viveu com os pais durante a infância, porém são falecidos, ambos de câncer. Sua relação familiar era boa, mas o pai era alcoólatra e agredia sua mãe frequentemente. A mãe cometia violência física contra ela e os irmãos. Seu primeiro marido a agredia. Se separou dele e perdeu a guarda da filha. Esta, era agredida pelo pai e pela madrasta. Cada filho é de um pai diferente e o atual marido é agressivo e a agride violentamente. Como está grávida, refere não estar sendo agredida. Ela comete violência física, psicológica e negligência com os 3 filhos e recuperou a guarda de todos eles, pois eram mais mal tratados pelo pai que por ela. Fez a seguinte afirmação: "Bater, a gente tem que corrigir, de uma forma que não mata..." Refere não ter paciência para dialogar com os filhos. 
- I dade: 38

- Ocupação: Do lar

- Nível de escolaridade: 3ạ série incompleta

- Estado civil: Casada

- Renda familiar: $\mathrm{R} \$ 300,00$

- Número de membros que moram juntos: 7

- Desempregados: 1

- Número de filhos: 4 (18a, 15a, 13a, 10a e neto de 2a)

- História: Morou com os pais até os 5 anos de idade, quando a mãe faleceu. O pai era negligente, então foi criada pela tia paterna dos 6 aos 18 anos. Começou a trabalhar com 12 anos, primeiro como empregada doméstica, depois na roça. Refere que casou para sair de casa, porém não tem um bom relacionamento com o marido, que é alcoólatra e usuário de drogas. Tem muita dificuldade financeira e, às vezes, passa fome. Diz ter vontade de se suicidar ou de matar o marido. É agredida por ele e já agrediu os filhos. 
- I dade: 42

- Ocupação: Do lar

- Nível de escolaridade: Analfabeta

- Estado civil: Separada

- Renda familiar: $\mathrm{R} \$ 500,00$

- Número de membros que moram juntos: 8

- Desempregados: 1

- Número de filhos: 9 + 2 filhos de criação (28a e 4a)

- História: Morou com os pais até os 8 anos de idade, quando eles faleceram. Começou a trabalhar na roça com 7 anos para sustentar os pais, que estavam doentes. Foi, então, morar na rua e acabou se casando com 9 anos. Perdeu dois irmãos: uma irmã de hemorragia por tentativa de aborto e um irmão por bronquite asmática. Ficou grávida aos 14 anos e tem 9 filhos do mesmo marido. Tem uma ótima relação com os filhos. Atualmente, separou-se do marido, pois ele a traiu e, no fim da relação, foi agredida por ele. Gosta de ser mãe e dialoga bastante com os filhos, que a respeitam muito. Contudo, já os agrediu fisicamente. 